\title{
An Assessment Of Reform Options For The Public Service Pension Fund In Uganda
}

\author{
Tatyana Bogomolova, Gregorio Impavido, Montserrat \\ Pallares-Miralles ${ }^{\dagger}$
}

The World Bank

\begin{abstract}
This paper analyzes the future liabilities that the Ugandan Public Service Pensions Fund might accumulate under the provisions of CAP 286, unless it is reformed. It then discusses alternative reform options that can be used as input in designing an educated homegrown reform of the fund. The paper supports a hybrid (two-pillar) reform option composed by a small defined benefit scheme and a complementary defined contribution scheme, instead of a pure defined contribution (monopillar) reform option discussed by policymakers in the country. The main reason for this is related to the fact that hybrid and pure defined contribution reforms will have the same impact on reducing pension expenditure (for same grandfathering rules and surplus in the first pillar). In addition, everything else being equal, the hybrid reform is likely to produce higher average replacement rates due to the redistributive and pooling properties of the small DB pillar.
\end{abstract}

World Bank Policy Research Working Paper 4091, Revised February 2007

The Policy Research Working Paper Series disseminates the findings of work in progress to encourage the exchange of ideas about development issues. An objective of the series is to get the findings out quickly, even if the presentations are less than fully polished. The papers carry the names of the authors and should be cited accordingly. The findings, interpretations, and conclusions expressed in this paper are entirely those of the authors. They do not necessarily represent the view of the World Bank, its Executive Directors, or the countries they represent. Policy Research Working Papers are available online at http://econ.worldbank.org.

\section{JEL Classification Codes:}

Keywords: Uganda, Pension Reform, Civil Service Scheme, Pension System

${ }^{\dagger}$ Tatyana Bogomolova (tbogomolova@worldbank.org) is Social Protection Specialist, Gregorio Impavido (gimpavido@worldbank.org) is Senior Financial Economist and Montserrat PallaresMiralles (mpallaresmiralle@worldbank.org) is Social Protection Specialist, all at the World Bank. This paper reflects the view of its authors, not necessarily those of the affiliation institution. 


\section{ACKNOWLEDGMENTS}

Bank staff who contributed to this simulation analysis of Public Service Pension Fund (PSPF) included Gregorio Impavido (LCSFF and project coordinator), Tatyana Bogomolova and Montserrat Pallares-Miralles (both HDNSP). The authors of the paper benefited from a first mission to Kampala in December 2004 where they held meetings with officials from the Ministry of Public Service (MPS), the Ministry of Finance, Planning and Economic Development (MOFPED), the Ministry of Defense (MOD), the Uganda Insurance Commission (UIC), the Capital Market Authority (CMA), and the Kampala City Council (KCC). During this first mission, data for the projections were collected and a one-week PROST training was delivered to MPS, MOFPED, and KCC officials at the Makerere University. The authors had the opportunity to visit Kampala again, in April 2005, when they met also with staff at the Uganda Bureau of Statistics (UBOS) to complete the data collection, revise the baseline, discuss preliminary findings with government officials and agree on alternative options for reforming PSPF.

The team would like to acknowledge the cooperation and support received from the managers and the staff of the institutions and agencies aforementioned, as well as the comments provided by Yee Mun Sin (HDNSP) and Rodney Lester (OPD) during the internal review process. The team is particularly grateful to Mr. Stephen Kunsa and his team in MPS for the extensive comments received during the various stages of preparation of this paper. 


\section{ABBREVIATIONS AND ACRONYMS}

$\begin{array}{ll}\text { AFPF } & \text { Armed Forces Pension Fund } \\ \text { CCK } & \text { City Council of Kampala } \\ \text { CMA } & \text { Capital Market Authority } \\ \text { CPG } & \text { Commuted Pension Gratuity } \\ \text { DB } & \text { Defined Benefit } \\ \text { DC } & \text { Defined Contribution } \\ \text { JE } & \text { Job Evaluation } \\ \text { MOD } & \text { Ministry of Defense } \\ \text { MOFPED } & \text { Ministry of Finance, Planning and Economic Development } \\ \text { MPS } & \text { Ministry of Public Service } \\ \text { NSSF } & \text { National Social Security Fund } \\ \text { PROST } & \text { Pension Reform Options Simulation Toolkit } \\ \text { PRP } & \text { Pay Review Policy } \\ \text { PSPF } & \text { Public Service Pension Fund } \\ \text { UBOS } & \text { Uganda Bureau of Statistics } \\ \text { UIC } & \text { Uganda Insurance Commission }\end{array}$




\section{PENSIONS TERMINOLOGY}

\begin{tabular}{|c|c|}
\hline Accrual replacement rate & $\begin{array}{l}\text { The rate at which pension entitlement is built up } \\
\text { relative to wages (in earning-related schemes) }\end{array}$ \\
\hline Defined benefit & Benefit based on a prescribed formula \\
\hline Funding & $\begin{array}{l}\text { Accumulation of assets in advance to meet future } \\
\text { pension liabilities }\end{array}$ \\
\hline Implicit pension debt (IPD) & $\begin{array}{l}\text { Liabilities accrued to date calculated as the present } \\
\text { value of future payments for all contributors and } \\
\text { beneficiaries based on length of service at the time } \\
\text { of measurement using projected wages. }\end{array}$ \\
\hline Indexation & $\begin{array}{l}\text { Increases in benefits by reference to an index, } \\
\text { usually of prices, or average earnings }\end{array}$ \\
\hline Length of service (LOS) & $\begin{array}{l}\text { Number of years a worker has contributed to a } \\
\text { system }\end{array}$ \\
\hline Old-Age dependency ratio & The ratio of older persons to working-age individuals \\
\hline PAYG (Pay-as-you-go) system & $\begin{array}{l}\text { A method of financing whereby current pension } \\
\text { expenditures are paid out of current revenues from } \\
\text { contributions (payroll taxes) }\end{array}$ \\
\hline Pensions contribution rate & $\begin{array}{l}\text { Payroll tax as percentage of an individual gross } \\
\text { wage for a pensions scheme }\end{array}$ \\
\hline Pension coverage rate & $\begin{array}{l}\text { The number of workers actively contributing to a } \\
\text { publicly mandated contributory retirement scheme, } \\
\text { divided by the estimated labour force or by the } \\
\text { working-age population }\end{array}$ \\
\hline Pension spending & $\begin{array}{l}\text { Defined here as old-age, survivor, and disability } \\
\text { payments }\end{array}$ \\
\hline Pension coverage rate & $\begin{array}{l}\text { The number of workers actively contributing to a } \\
\text { publicly mandated contributory retirement scheme, } \\
\text { divided by the estimated labour force or by the } \\
\text { working-age population }\end{array}$ \\
\hline Required contribution rate & $\begin{array}{l}\text { This is the rate at which contributions have to be } \\
\text { made (regardless of whether it is levied against the } \\
\text { employee or employer) in order to avoid subsidy } \\
\text { from any external source of funding (including } \\
\text { drawing down the reserve) and is often expressed } \\
\text { as a percentage of wage bill. }\end{array}$ \\
\hline Replacement Rate & $\begin{array}{l}\text { The value of a pension as a proportion of a worker's } \\
\text { wage during a base period, such as last year or } \\
\text { three years or fifteen or entire lifetime average wage } \\
\text {. It also denotes, as another definition, the average } \\
\text { pension of a group of pensioners as a proportion of } \\
\text { the average wage of the group }\end{array}$ \\
\hline System dependency ratio & $\begin{array}{l}\text { The ratio of persons receiving pensions from a } \\
\text { certain pension scheme divided by the number of } \\
\text { workers contributing to the same scheme in the } \\
\text { same period }\end{array}$ \\
\hline System maturation & $\begin{array}{l}\text { The process in which young people who are eligible } \\
\text { for pensions, in a new system, gradually grow old } \\
\text { and retire, thereby raising the system dependency } \\
\text { ratio to the demographic dependency ratio. In a fully } \\
\text { mature system, all old people in the covered group } \\
\text { are eligible for full pensions }\end{array}$ \\
\hline Wage base & $\begin{array}{l}\text { The portion of remuneration on which pension } \\
\text { benefits are calculated. Number of last years for } \\
\text { wage base calculation indicates the number of years } \\
\text { (average annual wages) that should be considered } \\
\text { as wage base }\end{array}$ \\
\hline
\end{tabular}




\section{TABLE OF CONTENTS}

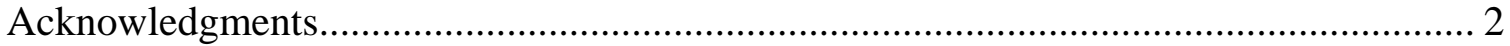

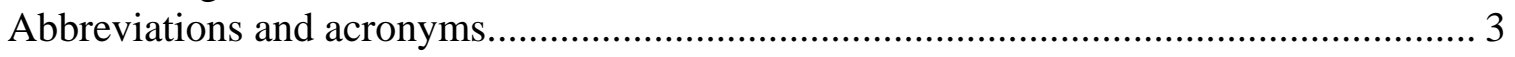

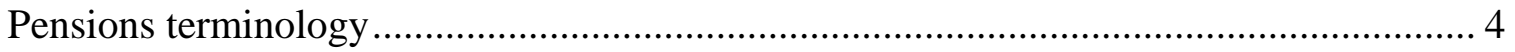

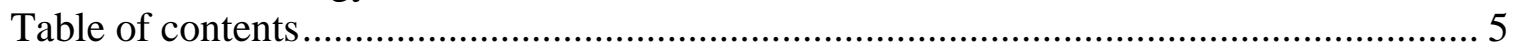

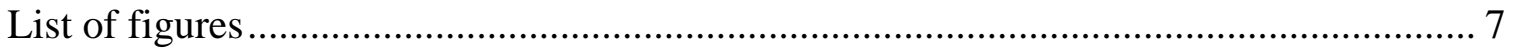

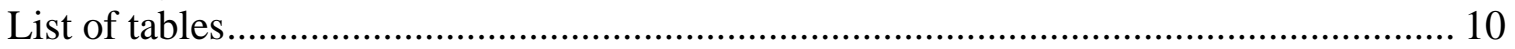

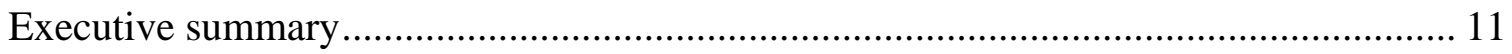

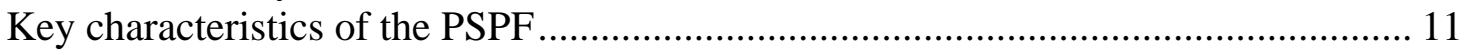

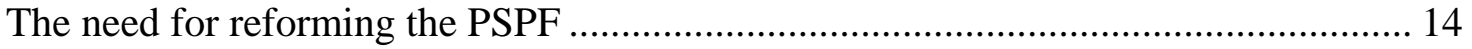

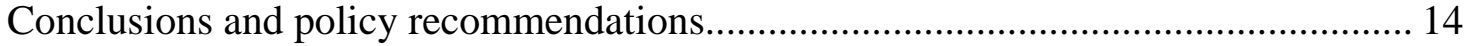

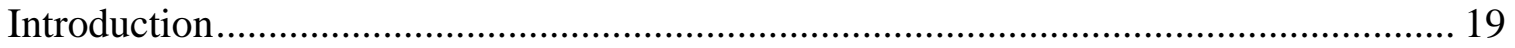

I The Ugandan pension system and the reform agenda ........................................ 21

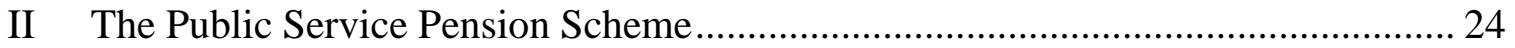

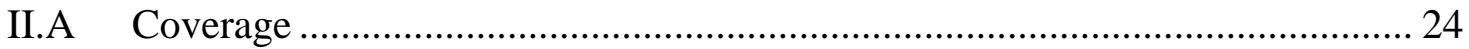

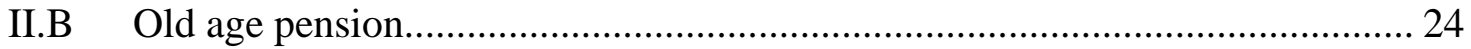

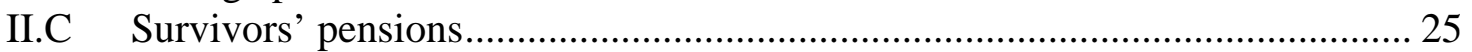

II.D Other gratuities......................................................................................... 26

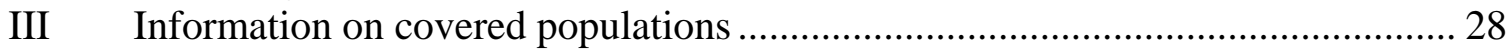

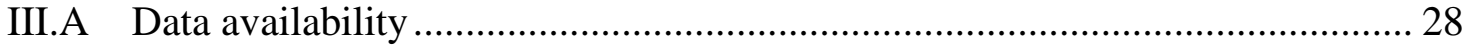

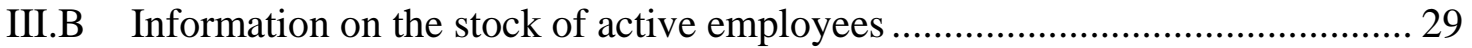

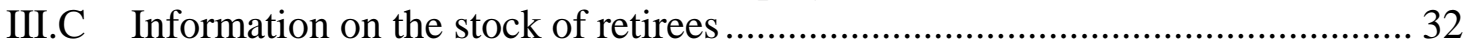

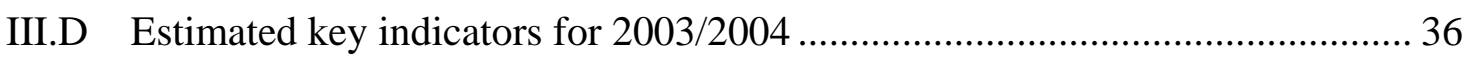

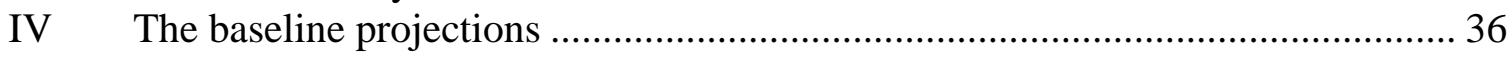

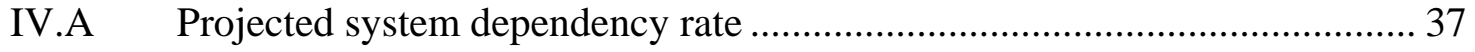

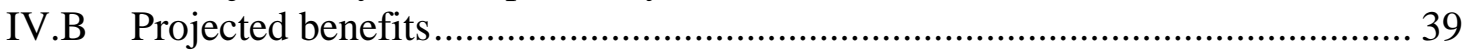

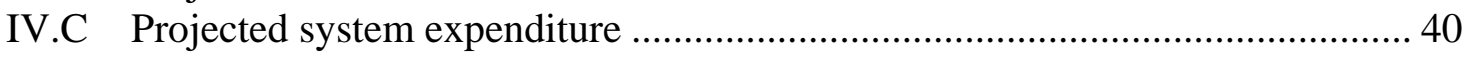

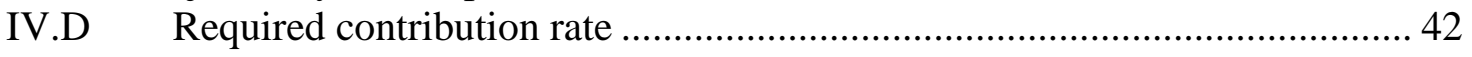

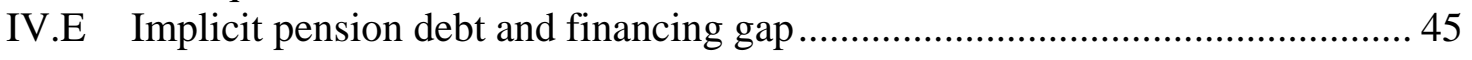

IV.F The role of the recruitment assumptions in baseline projections...................... 47

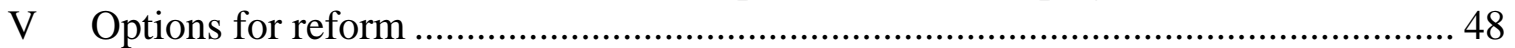

V.A Transforming PSPF into provident fund (Reform I)................................... 49

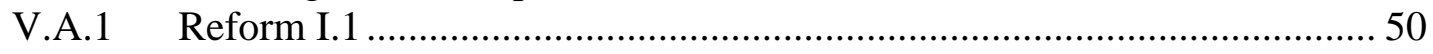

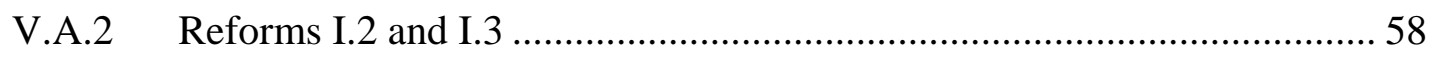

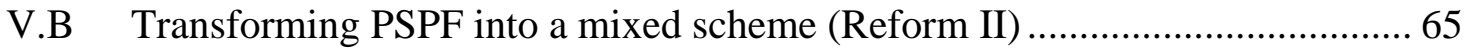

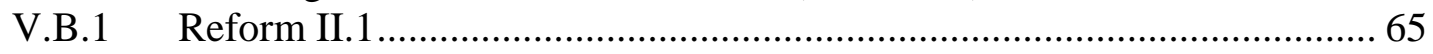

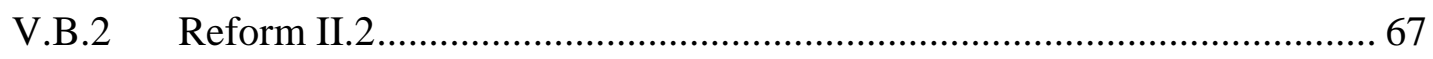

Conclusions and Policy Recommendations ............................................................. 71

Reforming the PSPF into a pure provident. ....................................................... 73

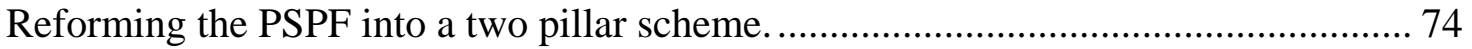

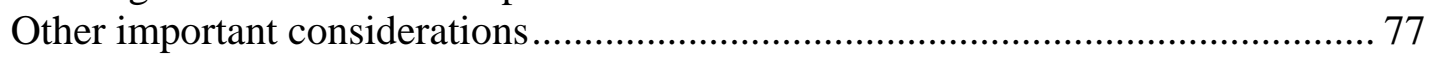

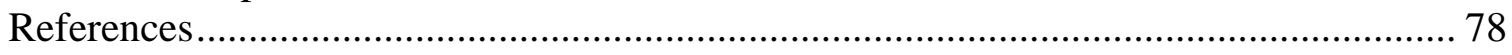

APPENDIX A Projection methodology and key assumptions ..................................... 79

APPENDIX B International experience on public service pensions arrangements ......... 90

APPENDIX C Implicit pension debt: cross country comparison................................... 93 


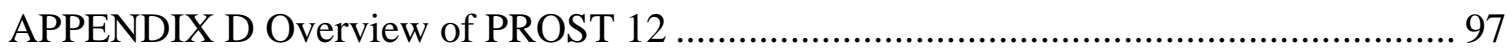

APPENDIX E Impact of Reforms on Individuals ....................................................... 100

APPENDIX F Impact of Wage Indexation............................................................. 107 


\section{LIST OF FIGURES}

Figure 1: More than $50 \%$ of civil servants are men between the ages of 30 and $50 * \ldots . .30$ Figure 2: More than $30 \%$ of all teachers are women between the ages of 17 and $60 * \ldots 30$ Figure 3: On average civil servants wages increase with age for both men and women*

Figure 4: On average teacher wages slightly increase with age for both men and women

Figure 5: Almost $90 \%$ of government retirees are men between the ages of 42 and 90 .. 33

Figure 6: 72\% of teacher retirees are men between the ages of 42 and $90^{*}$ 34

Figure 7: Age and gender distribution of the stock of civil servant retirees (2003/04,

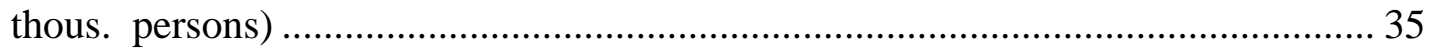

Figure 8: Age and gender distribution of the stock of teacher retirees (2003/04, thous. persons) 35

Figure 9: Projections of civil servant dependency rates* under two alternative mortality assumptions.

Figure 10: Projections of teacher dependency rates* under two alternative mortality assumptions show an increase, particularly starting in 2050 ................................ 38

Figure 11: Projected average replacement rates* for the stock of retirees (reduced pension only) are decreasing over time

Figure 12: Projected pension expenditure for civil servants (\% of GDP) is quite constant but exponentially increasing starting around 2040

Figure 13: Projected pension expenditure for teachers (\% of GDP) is only increasing during the entire simulation period

Figure 14: Required contribution rate needed to balance the scheme under two alternative mortality assumptions for civil servants

Figure 15: Required contribution rate needed to balance the scheme under two alternative mortality assumptions for teachers .................................................................. 44

Figure 16: Projected implicit pension debt* for civil servants (\% of GDP) increases

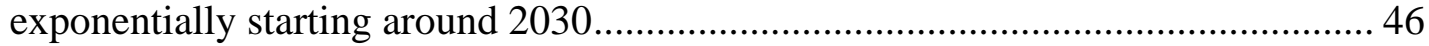

Figure 17: Projected implicit pension* debt for teachers (\% of GDP) only increases during the entire simulation period

Figure 18: Pure DC reform with immediate switching decreases considerably Government expenditure for civil servants, particularly in the medium and long term

Figure 19: Pure DC reform with immediate switching decreases considerably government expenditure for teachers, except for the very few first years of the simulation period*

Figure 20: Payment of accrued rights and contributions for civil servants - Reform I.1A (\% of GDP) 53

Figure 21: Payment of accrued rights and contributions for teachers - Reform I.1A (\% of GDP)

Figure 22: In a pure DC reform with immediate switching replacement rates* for stock of retirees for civil servants are lower than in the baseline scenario**....... 55 
Figure 23: In a pure DC reform with immediate switching replacement rates* for stock of retirees for teachers will be lower than in the baseline scenario** .......................... 56

Figure 24: In a pure DC reform, rate of return on assets makes a big difference on the replacement rates* in the DC component for civil servants**

Figure 25: In a pure DC reform, rate of return on assets makes a big difference on the replacement rates* in the DC component for teachers** ....................................... 58

Figure 26: Pure DC reforms make Government expenditure for civil servants much lower than in baseline scenario but comparable with hybrid reform* ............................. 59

Figure 27: Pure DC reforms make Government expenditure for teachers much lower than

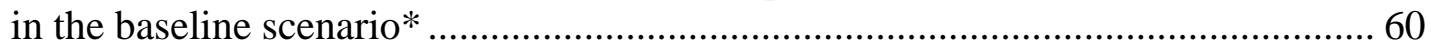

Figure 28: In a pure DC reform for only new entrants, replacement rates*, for non

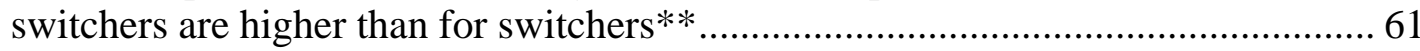

Figure 29: In a pure DC reform for only new entrants replacement rates* for nonswitchers are higher than for switchers**.....

Figure 30: Price indexation lowers Government expenditure for civil servants more than wage indexation does**

Figure 31: Price indexation lowers Government expenditure for teachers more than wage indexation does

Figure 32: Price indexation is another way to gradually decreasing replacement rates* for civil servants and reduce the fiscal impact of the current scheme ${ }^{* *}$...................... 64

Figure 33: Price indexation is another way to gradually decreasing replacement rates* for teachers and reduce the fiscal impact of the current scheme**

Figure 34: Hybrid reforms lowers Government expenditure for civil servants but expenditures patterns are identical to the pure DC reform*

Figure 35: Hybrid reforms lowers Government expenditure for teachers but expenditures patterns are identical to the pure DC reform*....

Figure 36: Comparison of replacement rates* for civil servant switchers- Reform II.2 with Reform I.2.

Figure 37: Comparison of replacement rates* for teacher switchers- Reform II.2 with Reform I.2

Figure 38: Projected civil servants average wage (\% of economy wide average wage) .. 81 Figure 39: Projected number of active employees (thous. persons) ............................... 85 Figure 40: Assumed age and gender distribution of new civil servants (\% of new recruits)

Figure 41: Assumed age and gender distribution of new teacher (\% of new recruits) ..... 86 Figure 42: Age specific retirement probabilities* for civil servants.............................. 87 Figure 43: Projected number of beneficiaries (thous. persons) .................................... 88

Figure 44: Assumed number of years of service at retirement ....................................... 89

Figure 45: Projected Pension Entitlements as a Proportion of the Average Wage under

No-Reform Scenario

Figure 46: Projected Pension Entitlements as a Proportion of the Average Wage under the Reform Scenarios

Figure 47: Post reform Relative Pension Levels as a share of No-Reform Relative

Pension Levels

Figure 48: Pension Wealth as a Portion of No-reform Pension Wealth 
Figure 49: Projected average replacement rates* for the stock of retirees (reduced pension

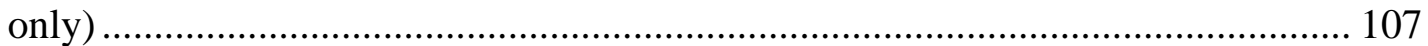

Figure 50: Projected pension expenditure (\% of GDP) ............................................... 107

Figure 51: Projected implicit pension debt* (\% of GDP)................................................ 108 


\section{LIST OF TABLES}

Table 1: Summary of key PSPF indicators, 2003/04 .................................................. 12

Table 2: Summary policy considerations under alternative reform options / 1 ............... 15

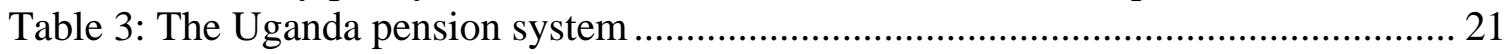

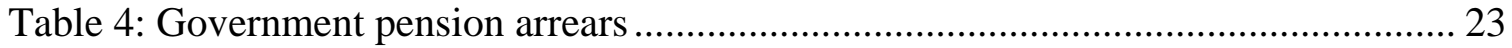

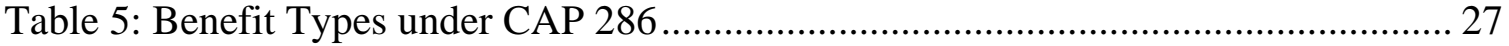

Table 6: Summary of data on the stock of employees, 2003/04 …............................... 29

Table 7: Summary of data on the stock of old age pensioners $(2003 / 04)$......................... 33

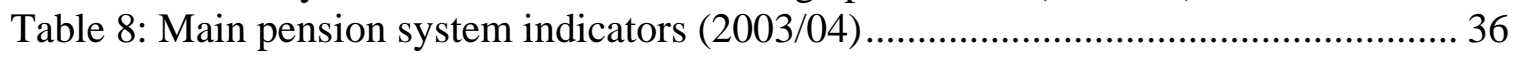

Table 9: Projected total pension expenditure (baseline: variant 1) ................................. 42

Table 10: The impact of lower covered population growth rates on end of simulation

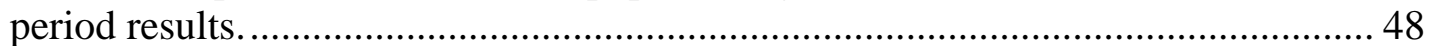

Table 11: Alternative scenarios under the pure DC and hybrid reform options ............... 49

Table 12: Projected average replacement rates* for the stock of retirees (average over

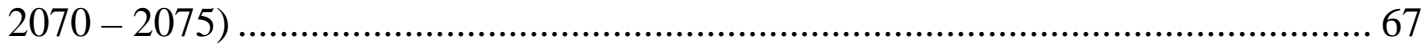

Table 13: Summary policy considerations under alternative reform options / 1 ............. 72

Table 14: Summary of the key outputs for alternative scenarios.................................. 76

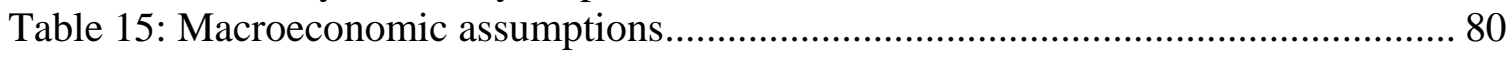

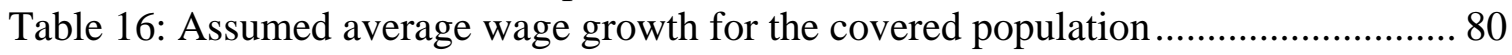

Table 17: Projected life expectancy* for the general population ................................... 82

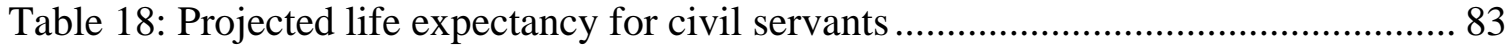

Table 19: Medium term active population growth assumptions..................................... 84

Table 20: Public debt, pension spending and implicit pension debt for 35 low and middle income countries for various years during the end-1990s and 2000 ...................... 94

Table 21: Estimated IPD for 35 Low and Middle Income Countries - detailed results.... 96

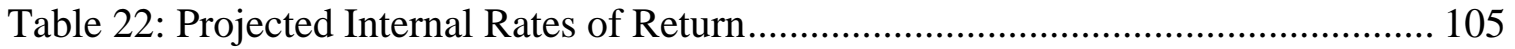




\section{EXECUTIVE SUMMARY}

This paper discusses the results of simulations conducted to project future Government liabilities stemming from the provision of the Pensions Act (CAP 286). It also discusses options for reforming the Public Service Pension Fund (PSPF). The projections were generated with the World Bank Pension Reform Options Simulation Toolkit (PROST) model, version 12 .

The paper builds on Deloitte and Touche (2001) and improves it in the following way: 1) it presents the demographic, macroeconomic, and recruitment policy assumptions used in the projections to facilitate replication of results; 2) it updates the assumptions needed for the projections by using the latest policy documents such as MPS (2001, 2003 and 2005) and GOU (2005); 3) it expands the analysis to also include civil servants outside the central government; and 4) it separates survivors from old age retirees.

In this executive summary we report some of the analysis made in the rest of the paper. All results reported critically depend on assumptions that cannot be adequately summarized here. For this reason the executive summary should not be read in isolation from the main paper and its appendices.

\section{Key characteristics of the PSPF}

The PSPF, regulated by CAP 286, is a non-contributory final salary defined benefit scheme covering traditional civil servants, civil servants in local authorities (districts, municipalities, town councils) and primary and secondary school teachers. Traditional civil servants include public employees in the central government, police officers, prison officers, doctors and public employees in the judiciary branch.

The MPS is responsible for administering benefit payments to individuals covered by CAP 286 and for administering benefit payment for the Armed Forces personnel as provided for by CAP 298. It is also responsible for record keeping of personnel data for active employers among traditional civil servants and teachers.

CAP 286 provides for old age defined pension benefits that can be partly commuted into a pension gratuity at retirement using a mechanistic formula disconnected from a proper actuarial evaluation; and for survivor's pension payable to orphans, widows and widowers and equivalent to $100 \%$ of the pension entitlement of the deceased public officers. CAP 286 also provides for gratuities for public officers serving on contract, for death, marriage, for police and prisons officers, and for short service.

The following table summarizes the main characteristics of the PSPF. The teachers and civil servants populations are very different. For the base year of our projections (2003/2004) the PSPF covered approximately 70,000 civil servants and 141,000 teacher employees and 13,000 civil servants and 11,000 teacher retirees globally accounting for only $1 \%$ of the Ugandan population. The civil servants employee population is on average older and with lower female participation. However teacher retirees are on average older and with a higher female participation. Average wage and average pensions are higher for civil servants than for teachers, irrespectively of gender considerations. The different population characteristics result in very different system dependency ratios: $29.1 \%$ for civil servants and $8.2 \%$ for teachers. 
Table 1: Summary of key PSPF indicators, 2003/04

\begin{tabular}{|c|c|c|c|}
\hline Covered working population & Unit & Civil servants & Teachers \\
\hline Number of men employees & 1,000 & 50.212 & 94.211 \\
\hline Number of women employees & 1,000 & 19.492 & 47.221 \\
\hline Number of employees & 1,000 & 69.704 & 141.432 \\
\hline Average age of men employees & 1,000 & 39.66 & 36.03 \\
\hline Average age of women employees & 1,000 & 37.80 & 33.03 \\
\hline Average age of employees & 1,000 & 39.14 & 35.03 \\
\hline Average annual salary of men & 1,000 & $2,862.3$ & $2,176.3$ \\
\hline Average annual salary of women & 1,000 & $2,701.2$ & $1,851.4$ \\
\hline Average annual salary & 1,000 & $2,817.4$ & $2,067.9$ \\
\hline Covered retired population & & Civil Servants & Teachers \\
\hline Number of men retirees & 1,000 & 12.155 & 8.297 \\
\hline Number of women retirees & 1,000 & 1.367 & 2.765 \\
\hline Number of retirees & 1,000 & 13.521 & 11.062 \\
\hline Average age of men retirees & 1,000 & 64.5 & 70.1 \\
\hline Average age of women retirees & 1,000 & 62.6 & 68.0 \\
\hline Average age of retirees & 1,000 & 64.3 & 69.6 \\
\hline Average annual pension of men / 1 & 1,000 & $2,301.7$ & $1,945.3$ \\
\hline Average annual pension of women $/ 1$ & 1,000 & $1,801.1$ & $1,198.3$ \\
\hline Average annual pension /1 & 1,000 & $2,248.5$ & $1,758.6$ \\
\hline Other indicators & & Civil Servants & Teachers \\
\hline System dependency ratio /2 & $\%$ & 29.1 & 8.2 \\
\hline Estimated total expenditure $/ 3$ & UGS mln & 71,180 & 48,831 \\
\hline Of which: & & & \\
\hline exp. for old-age pensioners (regular pensions) & UGS mln & 30,358 & 19,054 \\
\hline exp. for old-age pensioners (CPG payments) & UGS mln & 25,000 & 25,000 \\
\hline exp. for survivors (regular pensions) & UGS $\mathrm{mln}$ & 5,145 & 870 \\
\hline Other payments (non-CPG gratuities, etc.) /4 & UGS mln & 10,677 & 3,907 \\
\hline Total expenditure as \% of GDP & $\%$ & 0.59 & 0.40 \\
\hline Average old age pension replacement rates $/ 5$ & $\%$ & 79.7 & 83.4 \\
\hline \multicolumn{4}{|l|}{ Memo Items } \\
\hline$\overline{\mathrm{GDP}}$ & UGS mln & \multicolumn{2}{|c|}{$12,121,000$} \\
\hline Population & 1 & \multicolumn{2}{|c|}{$23,443,052$} \\
\hline
\end{tabular}

Notes: / 1 this includes only annuities from reduced and full pensions; /2 number of all beneficiaries divided by the number of active employees; /3 due to be paid in 2003/2004 excluding eventual arrears; /4 MPS experts' estimates; /5 average pension divided by the average covered wage (i.e., the wage received by active teachers or civil servant employees). Notice that this refers to only the reduced pension and excludes the CPG: i.e., 1/3 of full pension for the first 15 years of retirement.

Source: MPS, MOFPED.

The system dependency ratios are very low and would suggest that if the PSPF were to become a contributory scheme, it could become financially balanced with a relatively low contribution rate. However this first observation is not supported by a more careful analysis of the generosity of the scheme and long term trends in key indicators.

The system is rather generous by international standards. Individuals can retire at the early age of 45 , vesting periods of only 10 years are considered low, the benefit accrual 
rate is high at $2.4 \%$ per year, the reference wage for pension calculations is the last salary and benefits are indexed to wages.

In addition, in the next 70 years, system dependency rates are projected to increase from $23 \%$ to $35-40 \%$ for civil servants and from $80 \%$ to $40-45 \%$ for teachers. The higher increase for teachers is mainly driven by the two following factors: 1) the teacher subscheme is a much younger scheme and with maturation it ages more quickly than the more mature civil servant sub-scheme; and 2) the teacher population is expected to grow at a lower rate than the civil servant population.

As a consequence of the relatively generosity of the scheme and the expected deterioration of the system dependency ratio, system expenditure in the next 70 years is projected to grow from the current $0.6 \%$ and $0.4 \%$ of GDP per year to about $2.2 \%$ and $2.3 \%$ of GDP per year for civil servants and teachers, respectively.

The required contribution rate is a more intuitive indicator to measure the relatively generosity of the system. The required contribution rate assumes that the system is made contributory (but unreformed) and it is the required rate to make the system financially balanced. In other words, so that the volume of contributions to the fund equals the projected benefit outflows on a cash flow basis every year.

The required contribution rate for the civil servants sub-scheme starts from already a very high level of $36 \%$ which would not be sustainable even in a developed economy. Over time, it increases driven by the changes in the system dependency rate and it reaches around $40 \%$ by the end of the simulation period. The required contribution rate for the teachers' sub-scheme starts at the much lower level of 18\% much due to the much lower starting dependency rate. However, by the end of the simulation period exceeds the one projected for civil servants reaching about $45 \%$.

A final measure of the generosity and hence, fiscal impact, of the PSPF scheme is given by the implicit pension debt (IPD). The IPD calculated in this paper measures the accrued-to-date liabilities of the system if the system were to be closed at the time of measurement. For the base year, the total liabilities accrued by the system in both the civil servant and teacher sub-schemes are estimated at 23\% and 27\% of GDP respectively. Towards the end of the simulation period the combined IPD for the two sub-schemes is projected to reach $100 \%$ and $110 \%$ of GDP.

Notice that since the PSPF is non contributory, the IPD can also be interpreted as a measure of the redistributive property of the scheme from general population to the covered population. For the base year the covered population is $1 \%$ of the Ugandan population and it benefits (in present value terms) from a subsidy equivalent to $50 \%$ of GDP. Towards the end of the simulation period, the covered population is $2 \%$ of the Ugandan population and it benefits (in present value terms) from a subsidy equivalent to $100 \%$ of GDP.

It has to be noted that IPD calculations are highly sensitive to the choice of discount factor. For our calculations we used a rather generous $5 \%$ real discount rates. If more conservative measures were to be used the IPD estimates would be higher. 


\section{The need for reforming the PSPF}

The need for reforming the PSPF stems from the inability of rebalancing the scheme by simply making it contributory. Two main reform options are analyzed in the paper: 1) a systemic reform transforming the current scheme into a mono pillar pure provident fund; and 2) a systemic reform transforming the current scheme into a two pillar scheme maintaining a reformed and small defined benefit component and a larger defined contribution (or provident fund) component. We call the first reform "pure DC", "monopillar" or "provident fund" reform while we call the second reform "hybrid" or “two-pillar” reform.

In both reforms the new scheme is made contributory with a $15 \%$ contribution rate; $5 \%$ paid by employees and $10 \%$ paid by the employer (i.e., by the tax payer). The contribution rate was calibrated to maximize the fiscal impact of the reforms while providing adequate benefits in the vast majority of the scenarios presented and at the same time be sustainable in the long run.

Target expected replacement rates have been lowered to around $40-50 \%$ in the new scheme. How much lifetime earnings should be replaced on a mandatory basis should depend on a number of factors that are specific to the conditions in which the reform is undertaken. These include access to housing, health care, and other basic services, average propensity to save, the level of development, and the level of income in the country. International experience generally indicates that for a typical, full-career worker, an initial target of net-of-tax income replacement from mandatory systems is likely to be about 40 percent of real earnings to maintain subsistence levels of income in retirement . Lower-income workers will require somewhat higher rates while higherincome workers require lower levels. The age at retirement will also affect the measure of adequacy, with older workers requiring higher replacements rates because they have little potential to supplement pension benefits. Targeting average replacement rates above 60 percent is not likely to be viable over the long term because the required contribution rates would impose an untenable burden.

Two important policy choices need to be taken in the reform: 1) whether the new scheme will be open only to new entrants or also for the current working population; and 2) whether benefit indexation for current and future workers is changed or not. Another meaningful variation that is considered in the paper is whether the returns on assets accumulated are likely to be high or low. In the main body of the paper we detail all these different scenarios and combinations.

\section{Conclusions and policy recommendations}

The two main reform options of reforming the PSPF into either a pure provident fund or a hybrid two pillar scheme have both different advantages and disadvantages. In addition they also entail different types of risk summarized in the next table and discussed in the reminder of this section. 
Table 2: Summary policy considerations under alternative reform options / 1

\begin{tabular}{|c|c|c|}
\hline \multirow{3}{*}{ 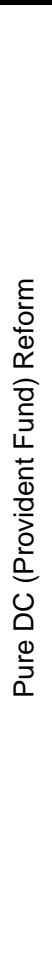 } & $\begin{array}{l}\text { Fiscal } \\
\text { impact }\end{array}$ & $\begin{array}{l}\text { Fully contributory reform. The pure provident fund reform with immediate switching and price } \\
\text { indexation for switchers has the strongest impact on government expenditure, identical to the } \\
\text { hybrid with same grandfathering rules. Tax revenues will only needed to pay for wages, } 10 \% \text { of } \\
\text { contributions, and accrued rights under the old scheme. Government expenditure is expected to } \\
\text { decrease in the short term and to increase again to about } 1 \% \text { of GDP in the long run. If more } \\
\text { generous grandfathering rules are adopted government expenditure will increase proportionally. }\end{array}$ \\
\hline & $\begin{array}{l}\text { Benefit } \\
\text { adequacy }\end{array}$ & $\begin{array}{l}\text { The pure provident fund reform with immediate switching and price indexation for switchers } \\
\text { reduces average expected replacement rates more than the hybrid reform with same } \\
\text { grandfathering rules. These are expected to fall rapidly to around } 42 \% \text { for civil servants and } 33 \% \\
\text { for teachers in the high interest rate scenario of } 5 \% \text { real for the next } 70 \text { years. If more generous } \\
\text { grandfathering rules are adopted, average replacement rates will increase proportionally but only in } \\
\text { the short and medium term. }\end{array}$ \\
\hline & $\begin{array}{l}\text { Other risks } \\
\text { and } \\
\text { benefits }\end{array}$ & $\begin{array}{l}\text { Weak governance may expose accumulated funds to under political influence. Under a more } \\
\text { realistic scenario of } 3 \% \text { real return replacement rates are expected to fall to about } 27 \% \text { for civil } \\
\text { servants and about } 21 \% \text { for teachers. } \\
\text { Members fully bear investment risk. } \\
\text { The scheme provides no longevity insurance. In addition, if members were to voluntarily } \\
\text { annuitize cash balances, they would bear annuitization risk. The current financial market institutions } \\
\text { are unable to safely provide private sector annuities. } \\
\text { The pure provident fund reform rapidly lowers expected replacement rates, thus not appealing } \\
\text { to current workers, including members of Parliament. } \\
\text { Capacity of MPS needs strengthening to forecast pension expenditure in the short run and manage } \\
\text { the new scheme including outsourcing of asset management }\end{array}$ \\
\hline \multirow[b]{3}{*}{ 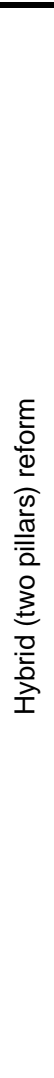 } & $\begin{array}{l}\text { Fiscal } \\
\text { impact }\end{array}$ & $\begin{array}{l}\text { Fully contributory reform. The hybrid reform with immediate switching and price indexation for } \\
\text { switchers has the strongest impact on government expenditure, identical to the pure provident } \\
\text { fund reform with same grandfathering rules as long as the first pillar is not in deficit. Tax } \\
\text { revenues will only needed to pay for wages, } 10 \% \text { of contributions, and accrued rights under the old } \\
\text { scheme. Government expenditure is expected to lower in the short term and increase to again to } \\
\text { about } 1 \% \text { of GDP in the long run. If more generous grandfathering rules are adopted government } \\
\text { expenditure will increase proportionally. }\end{array}$ \\
\hline & $\begin{array}{l}\text { Benefit } \\
\text { adequacy }\end{array}$ & $\begin{array}{l}\text { Average expected replacement rates in the hybrid reform with immediate switching and price } \\
\text { indexation for switchers are higher than in the pure provident fund reform with same } \\
\text { grandfathering rules. It will provide long run expected replacement of about } 42 \% \text { and about } 40 \% \text { for } \\
\text { civil servants and teachers, respectively, in the high rate of return scenario of } 5 \% \text { real for the next } 70 \\
\text { years. }\end{array}$ \\
\hline & $\begin{array}{l}\text { Other risks } \\
\text { and } \\
\text { benefits }\end{array}$ & $\begin{array}{l}\text { Weak governance may expose accumulated funds to undue political influence. Under a more } \\
\text { realistic scenario of } 3 \% \text { real return on assets, replacement rates are expected to fall to about } 34 \% \text { for } \\
\text { civil servants and } 35 \% \text { for teachers. These are still higher than the expected replacement rates } \\
\text { projected in the pure provident fund reform under the same interest rate scenario. } \\
\text { DB parameters (benefit indexation, contribution ceiling indexation and benefit formula parameters) } \\
\text { can be easily manipulated unless MPS develops strong modeling capacity to provide } \\
\text { quantitative answers to policy reform alternatives. } \\
\text { The hybrid reform provides a minimum longevity insurance unobtainable in the private sector. } \\
\text { The hybrid reform reduces the exposure of members to investment risk. } \\
\text { The hybrid reform ensures a more gradual transition to lower replacement rates, thus appealing } \\
\text { more to current workers, including members of Parliament. } \\
\text { Capacity of MPS needs strengthening to forecast pension expenditure in the short and long run for } \\
\text { the DB component, will need to manage a more complex scheme including outsourcing of asset } \\
\text { management }\end{array}$ \\
\hline
\end{tabular}

Notes: 1/ This is a summary of 7 alternative reform options discussed in the text. All numbers reported are indicative and would vary according to the specific scenario chosen. We refer to the text for a complete discussion of all the results. 
Reforming the PSPF into a pure provident fund with immediate switching of current workers and price indexation of benefits for new retirees has the strongest impact in relieving fiscal pressure in the medium and long run. Government expenditure is expected to remain constant at around 1\% of GDP over the whole simulation period. Notice, however that the fiscal impact is identical under the hybrid reform option for same grandfathering rules.

Reforming the PSPF into a pure provident fund with immediate switching of current workers and price indexation of benefits for new retirees has the strongest impact in reducing expected replacement rates. In the high rate of return on assets scenario replacement rates for the flow of retirees gradually decrease to $60 \%$ of average wage in the long run, less in the low rate of return scenario. Price indexation would further reduce replacement rates to $40 \%$ to $50 \%$ of average wage for the stock of retirees. Members of parliament, currently not covered by any scheme, will need to join the reformed scheme and may not support a reform that reduces benefits too rapidly. Finally, current civil servants may oppose, through lobbying, and even stall the reform process while seeking a compromise between budget alleviation and pension adequacy.

The provident fund option entails also some important risks. Replacement rates purely depend on realized returns on accumulated assets. A high rate of $5 \%$ real return on assets over the next 70 years is needed to support average replacement rates of $40 \%$ to $50 \%$ unless the covered population is prepared to contribute more than $15 \%$. This sustained high rate of return is considered unrealistic if the past experience of NSSF returns is taken as an example of the probable performance of the new scheme. Hence, it will be likely that ex post replacement rate will be much lower than what targeted making the provident fund reform option undesirable from the point of view of benefit adequacy. In our simulations, the use of a $3 \%$ real return reduces end of period expected replacement rates for civil servants and teachers to $27 \%$ and $21 \%$, respectively.

Though in relative terms a 50\% replacement rate appears to be adequate, it implies rather low benefits in absolute terms (money value) as wages in the public sector are very low compared to the economy wide average. This indicates that the reform of the PSPF should be accompanied by a reform of the civil service. The lack of progress in the comprehensive reform of the civil servant remuneration and hiring policy, together with the serious governance problems experienced by the NSSF in the past make a pure DC reform of the PSPF impractical. All this strongly suggests the following two policy recommendations:

1) a reform of the civil servant salary structure needs considering at the same time as the reform of the PSPF so that pay and pensions are considered integral, rather than separate, elements of compensation; and

2) a pure DC reform, irrespective of the switching patterns, should not be considered by the Ugandan authorities due to the inadequate retirement benefits that it is likely to produce.

The hybrid or two-pillar reform option mitigates some of the undesirable properties of the provident fund option. The hybrid reform has the same impact in reducing government expenditure for given grandfathering rules. The reason for this is due to the fact that when the first pillar is in surplus, the only source of expenditure is represented by: 1) 
wages; 2 ) the $10 \%$ contribution rate for the government to the new scheme; and 3) the pension expenditure for the grandfathered workers under the old scheme. Wages and the $10 \%$ contribution rate are identical under both reform options. Hence, pension expenditure is only determined by the grandfathering rules that policymakers will adopt. Immediate switching with price indexation of benefits to new retirees has the strongest impact in reducing pension expenditure. Allowing only new entrants to join the new scheme will have the weakest impact in reducing government expenditure.

The hybrid reform will provide higher expected replacement rates than the pure provident fund option due to the redistributive and pooling (insurance) properties of the small defined benefit first pillar.

In addition, the hybrid reform provides additional benefits. It provides a minimum annuity benefit, hence longevity insurance, in an environment not likely to be able to safely support privately managed annuities for the foreseeable future. It facilitates the introduction of sort of a minimum pension over the long run due to the effect of price indexation of the ceiling on contributions to the defined benefit component. It has better risk sharing properties when compared with the pure provident fund reform option as it maintains a modest intergenerational risk sharing dimension.

The hybrid reform also entails risks. The presence of a DB component leaves the door open for manipulation of DB parameters: especially of the benefit indexation, contribution ceiling indexation and defined benefit formula parameters. This risk should be mitigated by increasing the preparation and influence of MPS staff in analyzing the impact of pension variables and requiring their technical input in amending laws and regulations affecting the scheme. In addition, and similarly to the pure provident fund option, it entails the risk that poor governance of asset management will produce unsatisfactory average rates of return. This second risk is partly mitigated by the presence of a DB scheme.

All this suggests the following four policy recommendations:

A. A hybrid type of reform is more likely to provide adequate replacement rates than a pure DC reform as it provides a minimum longevity insurance that the private sector is likely not to be able to provide until the financial sector has reached a very different stage of development. The complementary DC component would grow at a lower rate giving time for financial sector development policies to be implemented.

B. The presence of a DB component leaves the door open for manipulation of DB parameters. This risk should be mitigated by increasing the preparation and influence of MPS staff in analyzing the impact of pension variables and requiring their technical input in amending laws and regulations affecting the scheme.

C. A contribution wage ceiling, indexed to prices, should be introduced to gradually reduce contributions to the DB component in line with ageing of the covered population and the development of the financial market. Ultimately, the effect of this policy would be to introduce a minimum pension for civil servants. 
D. Careful modeling will be needed to select those grandfathering rules that adequately trade-off the need to reduce government expenditure with the need to create political consensus in support of the reform.

In addition, critical preconditions for successfully reforming the scheme in any of the directions considered include the successful computerization and integration of the payroll systems of civil servants and teachers, the implementation of the pay reform strategy of 2001, strengthening of MPS capacity in modeling pension reform options and forecasting pension expenditure, and strengthening the governance standards of public pension fund management. 


\section{INTRODUCTION}

This paper discusses the results of simulations conducted to project future Government liabilities stemming from the provision of the Pensions Act (CAP 286). It also discusses options for reforming the Public Service Pension Fund (PSPF). The projections were generated with the World Bank Pension Reform Options Simulation Toolkit (PROST) model, version 12.

The results presented in this paper are based mainly on data obtained between December 2004 and April 2005 from the Ministry of Finance Planning and Economic Development (MOFPED), the Ministry of Public Service (MPS), and the Kampala City Council (KCC). Other sources of data and assumptions needed for the projections are listed in the reference section at the end of this paper. All assumptions used in the simulations were discussed and agreed upon with MPS officials.

The analysis conducted addresses one of the four reform priorities of the Government of Uganda, detailed in a draft cabinet paper. Such draft includes the strategy for reforming the pension system in the country as one of the priorities. At the time of writing, the document was supposed to be submitted to cabinet by the end of fiscal year 2004/05 for discussion. The paper builds on Deloitte and Touche (2001) and improves it in the following way: 1) it presents the demographic, macroeconomic, and recruitment policy assumptions used in the projections to facilitate replication of results; 2) it updates the assumptions needed for the projections by using the latest policy documents such as MPS (2001, 2003 and 2005) and GOU (2005); 3) it expands the analysis to also include civil servants outside the central government; and 4) it separates survivors from old age retirees.

The paper is structured in the following way: section I provides a snapshot of the Ugandan pension system and summary information on the reform agenda pending with the Government; section II provides a detailed description of PSPF scheme and the legal provision contained in CAP 286; section III reports quantitative information on the different populations covered by the scheme based on the data collected for our simulations; section IV presents what is commonly referred to as "the baseline" projections: i.e., long run projections of key variables for the scheme if it is not reformed; and section $\mathrm{V}$ presents alternative reform options, including options suggested by officials in the Ministry of Public Service. Conclusions follow in the last section.

The analysis is technical in nature but targets both technical and non-technical audiences. APPENDIX A explains in detail the projection/simulation methodology and key assumptions used in our exercise. This can be safely skipped by readers who do not wish to, or are already familiar with, the modeling methodology used for the projections. All important results derived in sections IV and V are summarized in the last section where policy conclusions are drawn.

APPENDIX E provides an in-depth analysis of the adequacy of pension benefits under the proposed reform scenarios by looking at the potential impact of reforms on different types of individuals representative of four different sub-groups of the civil servant population and selected in consultation with officials in MPS. The four representative types are: 1) teacher or policeman; 2) head teacher; 3) commissioner; and 4) Permanent 
Secretary. The appendix, together with the results contained in the main body of the paper related to only the "average" civil servant, allow for a better appreciation of the impact on pension benefits that the alternative reform options discussed in the text are likely to have for ten different types (distinguished also by gender) of civil servants. 


\section{THE UGANDAN PENSION SYSTEM AND THE REFORM AGENDA}

Uganda has a pension system similar to most Anglo-speaking countries in Africa: it covers a small proportion $^{1}$ of the labor force and it has accumulated assets of only about $0.6 \%$ of GDP.

Private sector workers in companies with more than five employees are covered by the National Social Security Fund (NSSF) which was established in 1985. Public sector workers are covered by two schemes. Central government officers, local authority officers (including teachers) and disciplined forces (police and prisons) are covered by the PSPF which was established on January $1^{\text {st }}$, 1946. Armed Forces personnel are covered by the Armed Forces Pension Scheme (AFPS), established on September $3^{\text {rd }}$, 1939. Few voluntary occupational schemes are active but they are not regulated. There is no pension supervisor in Uganda.

The following table summarizes the basic characteristics of the schemes just mentioned.

Table 3: The Uganda pension system

\begin{tabular}{|c|c|c|c|c|c|}
\hline & PSPF & PSPF /1 & AFPS & NSSF & OPS \\
\hline $\begin{array}{l}\text { Legal } \\
\text { framework }\end{array}$ & $\begin{array}{c}\text { Pensions Act (CAP } \\
286) / 4\end{array}$ & $\begin{array}{l}\text { Pensions Act } \\
\text { (CAP 286) }\end{array}$ & $\begin{array}{l}\text { Armed Forces } \\
\text { Pensions Act } \\
\text { (CAP 298) }\end{array}$ & $\begin{array}{c}\text { National Social } \\
\text { Security Act } \\
\text { (NNSF Act. } \\
1985 \text { ) }\end{array}$ & Not regulated \\
\hline Membership & $\begin{array}{l}\text { Traditional civil } \\
\text { servants (central } \\
\text { government, } \\
\text { police and } \\
\text { prison officers, } \\
\text { judiciary and } \\
\text { doctors) and } \\
\text { primary and } \\
\text { secondary school } \\
\text { teachers }\end{array}$ & $\begin{array}{l}\text { Public officers } \\
\text { in local } \\
\text { authorities } \\
\text { (District, } \\
\text { municipality, } \\
\text { and town } \\
\text { councils) }\end{array}$ & $\begin{array}{l}\text { Military } \\
\text { officers }\end{array}$ & $\begin{array}{l}\text { Formal sector } \\
\text { workers in } \\
\text { companies with } \\
\text { more than } 5 \\
\text { employees, } \\
\text { voluntary for } \\
\quad \text { others }\end{array}$ & $\begin{array}{c}\text { Formal sector } \\
\text { workers in } \\
\text { companies that } \\
\text { have voluntary } \\
\text { schemes }\end{array}$ \\
\hline $\begin{array}{l}\text { Funding } \\
\text { status }\end{array}$ & Unfunded & Unfunded & Unfunded & Funded & Funded /3 \\
\hline $\begin{array}{l}\text { Benefit } \\
\text { financing }\end{array}$ & $\begin{array}{l}\text { Non contributory } \\
\text { (Central } \\
\text { Government tax } \\
\text { revenues) }\end{array}$ & $\begin{array}{c}\text { Non } \\
\text { contributory } \\
\text { (Local } \\
\text { Government tax } \\
\text { revenues) }\end{array}$ & $\begin{array}{c}\text { Non } \\
\text { contributory } \\
\text { (Central } \\
\text { Government } \\
\text { tax revenues) }\end{array}$ & $\begin{array}{l}\text { Contributory } \\
\text { (10\% Employers, } \\
5 \% \text { employees ) }\end{array}$ & $\begin{array}{l}\text { Employers' } \\
\text { contributions }\end{array}$ \\
\hline $\begin{array}{l}\text { Scheme } \\
\text { Design }\end{array}$ & Defined benefit & Defined benefit & $\begin{array}{l}\text { Defined } \\
\text { benefit }\end{array}$ & $\begin{array}{l}\text { Defined } \\
\text { contribution }\end{array}$ & $\begin{array}{c}\text { Defined } \\
\text { contribution } \\
\text { and defined } \\
\text { benefit }\end{array}$ \\
\hline $\begin{array}{l}\text { Benefit } \\
\text { types }\end{array}$ & $\begin{array}{c}\text { Annuities and } \\
\text { lump sums }\end{array}$ & $\begin{array}{l}\text { Annuities and } \\
\text { lump sums }\end{array}$ & $\begin{array}{c}\text { Annuities and } \\
\text { lump sums }\end{array}$ & Lump sums & $\begin{array}{l}\text { Annuities and } \\
\text { lump sums }\end{array}$ \\
\hline \multicolumn{6}{|c|}{$\begin{array}{l}\text { Notes: / } 1 \text { Urban authorities, until 1994, had their own provident funds established under the provisions of the } \\
\text { Municipalities and Public Authorities Provident Fund (CAP 291). After the } 1994 \text { amendment of the Pensions Act, all } \\
\text { urban authorities were required to provide pensions to their workers under the Pensions Act CAP 286. /2 Voluntary } \\
\text { arrangements take the form of trust deeds/plans. /3 The funding status of voluntary occupational schemes is not clearly } \\
\text { ascertained as these schemes are currently not regulated and supervised; / } 4 \text { The number of the pension act was changed } \\
\text { in } 2006 \text { from } 281 \text { to } 286 \text {. }\end{array}$} \\
\hline
\end{tabular}

\footnotetext{
${ }^{1}$ The STG (2003) paper indicates that over 95\% of the population in Uganda is excluded from the current formal social protection coverage.
} 
The pension system in Uganda is afflicted by a long series of problems. Serious issues of governance and mismanagement affect NSSF. PSPF and AFPS are very generous schemes crowding out precious resources in the budget. Voluntary schemes are unregulated. The overall regulatory framework is weak and there is no agency in place to supervise the pension system.

While the pension policy debate is being extended to include a large number of stakeholders, it is effectively limited to only a few individuals due to the weak capacity in many institutions/agencies to understand pension policy issues. Nevertheless, the process strives at achieving high transparency, and extensive consultation with various stakeholders.

Finally, due to budget limitations of the central and local governments and ad hoc revisions of benefit formulas that underestimated the impact on future liabilities, the Uganda government has accumulated substantial arrears in the area of pensions that are estimated in the neighborhood of US\$ 150 to 200 million. These liabilities are mostly in UGS but around US\$ 24 million are also due in foreign currency. The following table reports outstanding claims grouped in the two currencies and in 8 major categories. 
An Assessment Of Reform Options For The Public Service Pension Fund In Uganda

Table 4: Government pension arrears

\begin{tabular}{|c|c|c|}
\hline Cat. & $\begin{array}{l}\text { Estimated } \\
\text { Amount }\end{array}$ & Description \\
\hline \multicolumn{3}{|c|}{ Foreign currency liabilities } \\
\hline A & $\begin{array}{l}\text { US\$ } 12 \\
\text { mln. }\end{array}$ & $\begin{array}{l}\text { Since } 1977 \text { pensions to various categories of workers of the East } \\
\text { African Community have not been paid. As of } 2001 \text { these have been paid } \\
\text { but only pensions related to employees of the East African Airways are } \\
\text { currently being paid. The due amount was estimated in June 2006at } \\
\text { US } \$ 12 \text { million earning a } 7 \% \text { annual interest. }\end{array}$ \\
\hline \multirow[t]{2}{*}{ B } & $\begin{array}{l}\text { US\$ } 2.3 \\
\text { mln. }\end{array}$ & $\begin{array}{l}\text { Residual category of East African Community pensions earning } 7 \% \\
\text { interest annually. Totally paid as of June } 2006 \text {. }\end{array}$ \\
\hline & $\begin{array}{l}\text { US\$ } 12 \\
\text { mIn. }\end{array}$ & Total estimate US\$ arrears as of June 2006. \\
\hline \multicolumn{3}{|c|}{ Local currency liabilities } \\
\hline $\mathbf{C}$ & $\begin{array}{l}\text { UGS } 19 \\
\text { bln. }\end{array}$ & $\begin{array}{l}\text { Gratuities to contractual workers, political leaders and commuted } \\
\text { pensions. There are some } 1,200 \text { people in this category }\end{array}$ \\
\hline D & $\begin{array}{l}\text { UGS } 79 \\
\text { bln. }\end{array}$ & $\begin{array}{l}\text { The high inflation since } 1987 \text { prompted legislator to amend the Pension } \\
\text { Act (CAP 286) and introduce wage indexation of pensions in } 1995 \text {. This } \\
\text { applied retroactively to all wage increases since } 1988 \text {. UGS } 79 \text { bln is } \\
\text { what is still unpaid of the liability increase created by the } \\
\text { introduction of wage indexation. }\end{array}$ \\
\hline $\mathbf{E}$ & $\begin{array}{l}\text { UGS } 107 \\
\text { bln. }\end{array}$ & Pensions to members of disbanded armies. \\
\hline $\mathbf{F}$ & $\begin{array}{l}\text { UGS } 20 \\
\text { bln. }\end{array}$ & Survivors' pensions of defense personnel \\
\hline G & $\begin{array}{l}\text { UGS } 17.5 \\
\text { bln. }\end{array}$ & $\begin{array}{l}\text { Local government pensions. Local governments are required to fund } \\
\text { their pension liabilities through local taxes. However, in } 2001 \text {, the } \\
\text { central government agreed to fund the liabilities accrued up to that } \\
\text { year. The agreement excluded liabilities associated to wage } \\
\text { indexation of pensions. The financial situation of local authorities } \\
\text { has not improved since } 2001 \text { and local authorities are accruing } \\
\text { liabilities as per provisions of CAP } 286 \text {. }\end{array}$ \\
\hline \multirow[t]{2}{*}{$\mathbf{H}$} & $\begin{array}{l}\text { UGS } 20 \\
\text { bln. }\end{array}$ & Gratuities of ISO/ESO (intelligence) personnel. \\
\hline & $\begin{array}{l}\text { UGS } 142 \\
\text { bln. }\end{array}$ & $\begin{array}{l}\text { Total estimate UGS arrears as of June } 2006 \text { using exchange rate as of } \\
06 / 30 / 2006 \text { of } 1 \text { US } \$=\text { UG } \$ 1,841 \text {. }\end{array}$ \\
\hline
\end{tabular}

Source: discussions with MPS officials.

The arrears listed above do not affect our projections. This is because the commuted pension is not paid to new retirees (category C), and the reduced pension, to both new (flow) and old (stock) of retirees, is paid in full. However, the arrears certainly need to be considered as part of the implicit pension debt calculated in the next sections, in order to estimate the total pension liabilities (implicit and explicit) that the government has accumulated.

The reform of the pension system, in general, has been pending with the government for a long time. During this period the Ugandan authorities have benefited from the advice of various parties. The content of large numbers of reports written so far on this matter is summarized in Callund (2004). A draft cabinet paper was submitted to cabinet at the end of the fiscal year 2004/05 detailing general principles for reforming the pension system. Four main issues were covered in the paper: 1) design of adequate regulatory and supervisory framework for all retirement benefit schemes; 2) liberalization of the pension system aimed at promoting choice among covered population and participation of private 
sector service providers; 3) reform of PSPF to reduce the fiscal pressure on the budget; and 4) reform of NSSF to improve governance and asset management, as well as reduce its monopoly in the management of mandatory contributions. At present, the document has yet to be discussed in the Cabinet.

Nevertheless, the Cabinet approved to reform the PSPF scheme from non-contributory to contributory. It is within this framework that this paper provides an analysis of options for reforming the scheme while transforming it into a contributory scheme.

The following section provides a more detailed description of the benefit and entitlement provisions contained in CAP 286.

\section{The Public Service Pension Scheme}

\section{II.A Coverage}

CAP 286 regulates the pension arrangements for traditional civil servants, civil servants in local authorities (districts, municipalities, town councils) and primary and secondary school teachers. Traditional civil servants include public employees in the central government, police officers, prison officers, doctors and public employees in the judiciary branch. In this paper we model pension liabilities for two sets of populations. On the one hand, we group primary and secondary school teachers. On the other hand, we group all other public civil servants covered by CAP 286. The former group is referred to in what follows as "Teachers" while the latter group is referred to as "Civil Servants".

The MPS is responsible for administering benefit payments to individuals covered by CAP 286. ${ }^{2}$ It is also responsible for record keeping of personnel data for active employers among traditional civil servants and teachers.

\section{II.B Old age pension}

CAP 286 provides for several pension benefits in the form of lump sums (called in Uganda "gratuities") or annuities.

Old age pension can be obtained in the form of annuity only (called in Uganda "full pension") or as a combination of lump sum (called in Uganda "commuted pension gratuity") and a reduced annuity (called in Uganda "reduced pension”) ${ }^{3}$. Old age pension can be obtained on completion of twenty years of continuous service in a pensionable appointment or on the attainment of the age of forty five years and on completion of ten years of continuous service in a pensionable appointment. The full pension is based on final gross salary with an accrual ${ }^{4}$ factor of $2.4 \%$ multiplied by the number of years in

\footnotetext{
${ }^{2}$ MPS also administers benefits for Armed Forces personnel as provided for by CAP 298. However, it does not administer the scheme.

${ }^{3}$ The term "reduced pension" does not imply that a benefit lower than what is due is paid. Indeed, the government of Uganda is still paying pension arrears as explained in section I and budget limitations do not allow MPS to fully pay commuted pension gratuities and other gratuities. Nevertheless, reduced pensions are paid in full. This observation will become important when we use actual data pension expenditure from the base year to project pension liabilities in sections IV and V.

${ }^{4}$ This is commonly known in Uganda as the fraction of $1 / 500$.
} 
service and capped at $87 \%$ of final gross salary. Compulsory retirement age is at 60 for both men and women.

The commuted pension gratuity (CPG) is an advance payment of old age pension to newly retirees. It is the equivalent to $1 / 3$ of full pension that a new retiree would obtain in the following 15 years after retirement assuming no indexation is applied.

The reduced pension is the monthly pension that the new retiree obtains when it opts for the CPG. The reduced pension is restored to the full pension after 15 years.

Both the full pension and the reduced pensions are indexed to wages. However, the way indexation is computed for the reduced pension implies that reduced pensions grow more quickly than wages during the 15 years before restoration to full pension. ${ }^{5}$

Beyond the basic entitlement rules described before, CAP 286 also provides for the following old age pension entitlement rules:

- On abolition of office

- On compulsory retirement for the purpose of facilitating improvement in the organization of the department to which the officer belongs, by which greater efficiency or economy may be affected.

- On medical grounds, to the satisfaction of the Pensions Authority, that an officer is incapable by reason or any infirmity of mind or body of discharging duties of his/her office and that such infirmity is likely to be permanent.

- When one retires from the Public Service with the written consent of the President acting on the advice of the Public/Judicial/Education Service Commission, as the case may be.

- Where an officer is removed from the Public Service in the public interest, irrespective of the age of the officer at the date of removal, provided the officer had completed 10 years' service on permanent and pensionable terms.

- For a women officer who resigns on, or retires with a view to marriage or is required to retire on account of her marriage if she has served for a continuous period of five years.

- In the case of Police and Prisons officers below the ranks of Assistant Inspector and Principal Officer respectively, they must have served for at least 12 years.

- A member of the Police Force shall retire on attainment of 55 years of age or, they may retire regardless of age on successful completion of 20 years continuous service.

\section{II.C Survivors' pensions}

Pension to survivors (orphans, widows and widowers) is equivalent to $100 \%$ of the pension entitlement of the deceased public officers. This could be $100 \%$ of the full pension for qualifying deceased public officers in active duty or $100 \%$ of the full or reduced pension (whatever elected) for the retirees deceased in the first 15 years of

\footnotetext{
${ }^{5}$ See later the details on indexation of reduced pensions and how this was modeled in our simulations.
} 
retirement. Survivors' pensions are paid only up to 15 years. This means that a survivor of a deceased public officer in active service will obtain a pension for 15 years.

However, a survivor of a deceased retired public officer during the first 15 years of retirement will only obtain a survivor pension for the remainder of such 15 years.

\section{II.D Other gratuities}

Beyond the CPG described before, CAP 286 provides for a long series of other gratuities.

- Contract gratuities are awarded for non-pensionable service of public officers serving on contract. These gratuities are contractually determined.

- Death gratuities are paid to deceased public officers’ representatives or surviving relatives. The gratuity amounts to three times the salary of deceased person at death or the deceased person's CPG if entitled to it, whichever is higher.

- Short term gratuities are awarded to public officers retired on medical grounds or when they are dismissed in the interest of the public with at least 10 years of pensionable service. The gratuity is equivalent to $24 \%$ of the last annual salary multiplied by the number of years in service.

- Marriage gratuities are awarded to women public officers retiring on marriage grounds. The marriage gratuity is equivalent to $12 \%$ of the last salary multiplied by the number of years in service.

- Gratuities for Police officers are awarded when officers retire with a rank below the rank of assistant inspector with at least 13 years of pensionable service. Gratuities for Prison officers are awarded when officers retire with a rank below the rank of principal officer with at least 13 years of pensionable service. The gratuity for police and prisons officers is capped at 25\% of total emoluments.

The following table provides a summary of benefits and entitlement provisions contained in CAP 286. 
An Assessment Of Reform Options For The Public Service Pension Fund In Uganda

Table 5: Benefit Types under CAP 286

\begin{tabular}{|c|c|c|}
\hline Type of Benefit & Requirement/s & Formula \\
\hline $\begin{array}{r}\text { (a) 0ld age pensions } \\
\text { Full monthly pension } \\
\text { (if no CPG) } \\
\text { Commuted Pension } \\
\text { Gratuity (CPG) } \\
\text { Reduced Monthly Pension } \\
\text { (if CPG) }\end{array}$ & $\begin{array}{l}\text { Length of service } 20 \text { years, } \\
\text { or } 45 \text { years of age and } 10 \\
\text { years of service. Mandatory } \\
\text { retirement age: } 60 \\
\text { Length of service } 20 \text { years, } \\
\text { or } 45 \text { years of age and } 10 \\
\text { years of service. Mandatory } \\
\text { retirement age: } 60 \\
\text { Length of service } 20 \text { years, } \\
\text { or } 45 \text { years of age and } 10 \\
\text { years of service. Mandatory } \\
\text { retirement age: } 60\end{array}$ & $\begin{array}{c}\text { ( }(1 / 500 \text { th of the annual } \\
\text { salary before retirement } \\
\text { total number of months of } \\
\text { service }) / 12 \\
(1 / 500 \text { th of the annual } \\
\text { salary before retirement * } \\
\text { total number of months of } \\
\text { service }) \text { * }(1 / 3){ }^{*} 15 \\
(1 / 500 \text { th of the annual } \\
\text { salary before retirement * } \\
\text { total number of months of } \\
\text { service }) *(2 / 3) / 12\end{array}$ \\
\hline (b) Survivors' Benefits & $\begin{array}{l}\text { Paid to spouse and children } \\
\text { when pensioner/active member } \\
\text { dies before the expiry of } \\
\text { fifteen years after the date } \\
\text { of his/her retirement (for } \\
\text { full } 15 \text { years in case of } \\
\text { active member }\end{array}$ & $\begin{array}{l}\text { Pensioner/active member } \\
\text { monthly pension paid for up } \\
\text { to } 15 \text { years }\end{array}$ \\
\hline $\begin{array}{l}\text { (c) Pension on abolition of } \\
\text { office }\end{array}$ & Abolition of office & $\begin{array}{l}\text { Normal pension }+25 \% \text { of the } \\
\text { pension }+ \text { severance pay }+ \\
\text { repatriation expenses }+6 \\
\text { months pay in lieu of notice } \\
+ \text { payment in lieu of } \\
\text { approved earned leave }\end{array}$ \\
\hline $\begin{array}{l}\text { (d) Contract Gratuity for } \\
\text { Public officers serving on } \\
\text { contract }\end{array}$ & Contract agreement & $\begin{array}{l}\text { Gratuity computed according } \\
\text { to the terms of the contract } \\
\text { agreement. Usually a } \\
\text { prescribed percentage of the } \\
\text { annual gross salary }\end{array}$ \\
\hline (e) Death Gratuity & $\begin{array}{c}\text { Representative of a deceased } \\
\text { public officer }\end{array}$ & $\begin{array}{l}\text { Deceased public officers' } \\
\text { annual salary at the time of } \\
\text { death by three, or the } \\
\text { deceased officer's would- } \\
\text { have-been CPG, which ever is } \\
\text { greater }\end{array}$ \\
\hline (f) Short Service Gratuity & $\begin{array}{l}\text { Public officers retired in } \\
\text { the public interest or on } \\
\text { medical grounds provided } \\
\text { they had completed } 10 \text { years } \\
\text { of pensionable service }\end{array}$ & $\begin{array}{c}\text { (1/500th of the annual } \\
\text { salary before retirement } \\
\text { total number of months of } \\
\text { service) }{ }^{*} 10\end{array}$ \\
\hline (g) Marriage Gratuity & $\begin{array}{l}\text { Payable to women public } \\
\text { officers who retire on } \\
\text { marriage grounds }\end{array}$ & $\begin{array}{l}\text { (Total number of months * } \\
\text { annual salary) }{ }^{*} 5 / 500\end{array}$ \\
\hline $\begin{array}{l}\text { (h) Gratuity for Police and } \\
\text { Prisons officers }\end{array}$ & $\begin{array}{c}\text { Police office who retires } \\
\text { below the rank of assistant } \\
\text { inspector, or in case the } \\
\text { prisons service below the } \\
\text { rank of principal officer } \\
\text { and has served for } 12 \text { years, } \\
\text { or more }\end{array}$ & $\begin{array}{c}25 \% \text { of total emoluments or } \\
\text { less }\end{array}$ \\
\hline
\end{tabular}

Source: CAP 286. 


\section{INFORMATION ON COVERED POPULATIONS}

\section{III.A Data availability}

We have decided to divide (and simulate separately) teachers from other covered populations (central government civil servants, judiciary, doctors, local authority civil servants, prisons and police). Their different characteristics such as wages, age composition of the covered population, system dependency ratio, etcetera, play an important role in modeling. Consequently, two sets of data, one for teachers and one for civil servants, were collected as described below.

Pensioner data was provided by MPS, active member data was provided by MPS and MOFPED. Individual records of selected fields (age, gender, income, length of service) were provided for both active employees and beneficiaries, among traditional civil servants, local authorities and teachers. The following, is a complete list of data received directly and derived from the provided database for the base year of 2003/04:

a) Total number, as well as age (by single year age groups) and gender composition of public servants. Initially, these data included contractors and other nonpensionable categories of workers. Therefore, an additional dataset of individual records was provided. This allowed us to separate employees who are under pensionable and non-pensionable categories. As this dataset contained serious deficiencies (particularly on birth dates), several approximations were used. For instance, we ignored information on active employees younger than 14 years old. According to the dataset, only less than 3 percent of all active employees are nonpensionable: i.e., they do not accrue pension rights.

b) Wage distribution of active members by income brackets and gender. These data also included contractors and other non-pensionable categories of workers and had to be adjusted accordingly.

c) Age and gender distribution of wages (average wage for each single year age and gender group). As for a) and b) above, the dataset of individual records had to be adjusted to separate the non-pensionable from the pensionable categories of civil servants.

d) Age and gender distribution of new active members, recruited in 2003-2004.

e) Total number as well as age (by single year age groups) and gender composition for the stock of pensioners. The complete pensioner individual database was only available for all pensioners - old-age pensioners and survivors - together and did not contain fields indicating the beneficiary category. In addition, a representative sample of pensioner individual records (8,609 records) containing beneficiary category indicators was provided, though these data were not segregated by gender. The sample was used as a basis for separating survivors from old-age pensioners in the total beneficiary population.

f) Income distribution for the stock of pensioners. These data were also lumped together for all beneficiary categories, however - since survivors receive $100 \%$ of old age pensions of the deceased individuals - it was assumed that this distribution applies also to the stock of old age pensioners. 
An Assessment Of Reform Options For The Public Service Pension Fund In Uganda

g) Age and gender distribution of pensions (average pension for each single year age and gender group) for the stock of pensioners. Same as in f), this distribution was used for the stock of old age pensioners.

h) Flow of pensioners by age and gender retired in 2003/2004.

i) Length of service at retirement by single age and gender.

No data was available on the value of benefits due and actually paid, including a break down by categories of benefits. Estimates for the value of benefits relevant for our simulations (a) and (b) in Table 5 and actually due were derived from individual data. Estimates for the value of benefits (c) to (h) ${ }^{6}$ in Table 5 and actually due were provided by MPS. For civil servants and teachers the share of "other expenses" in the total was estimated to be about $15 \%$ and $8 \%$, respectively.

The following section summarizes the data available for projections.

\section{III.B Information on the stock of active employees}

Table 6 reports summary data on the stock of civil servants and teachers for the base year of 2003/04. Civil servants amounted to a total of 69,704 individuals with an average age of 39 and an average annual wage of UGS 2,817 thousands. Male civil servants amounted to 50,212 individuals with an average age of 40 and an average annual wage of UGS 2,862 thousands. Female employees are fewer (less than 30\%) and tend to be slightly younger, therefore earning a lower average wage than male employees despite very similar age distribution of wages.

The total number of teachers holding pensionable positions is 141,432, with an average age of 35 and an average annual wage of UGS 2,068 thousands. Like civil servants, female teachers are on average younger than their male counterparts and receive lower wages. It is interesting to note that in Uganda male teachers represent $67 \%$ of the teaching population while in most countries the gender distribution is generally reversed.

Table 6: Summary of data on the stock of employees, 2003/04

\begin{tabular}{|c|c|c|c|}
\hline & $2003 / 04$ & Civil servant employees & Teacher employees \\
\hline \multirow{3}{*}{ 흥 } & Men & 50.212 & 94.211 \\
\hline & Women & 19.492 & 47.221 \\
\hline & Total & 69.704 & 141.432 \\
\hline \multirow{3}{*}{ 安 } & Men & 39.66 & 36.03 \\
\hline & Women & 37.80 & 33.03 \\
\hline & Total & 39.14 & 35.03 \\
\hline \multirow{3}{*}{ 宅 } & Men & $2,862.3$ & $2,176.3$ \\
\hline & Women & $2,701.2$ & $1,851.4$ \\
\hline & Total & $2,817.4$ & $2,067.9$ \\
\hline
\end{tabular}

Source: MOFPED.

Figure 1 reports the age distribution of the 69,704 civil servants as of 2003/04 while the age distribution of the 141,432 teachers is presented in Figure 2.

\footnotetext{
${ }^{6}$ Categories (c) to (h) were modeled and will be referred to as "other expenses".
} 
Figure 1: More than $50 \%$ of civil servants are men between the ages of 30 and $50 *$

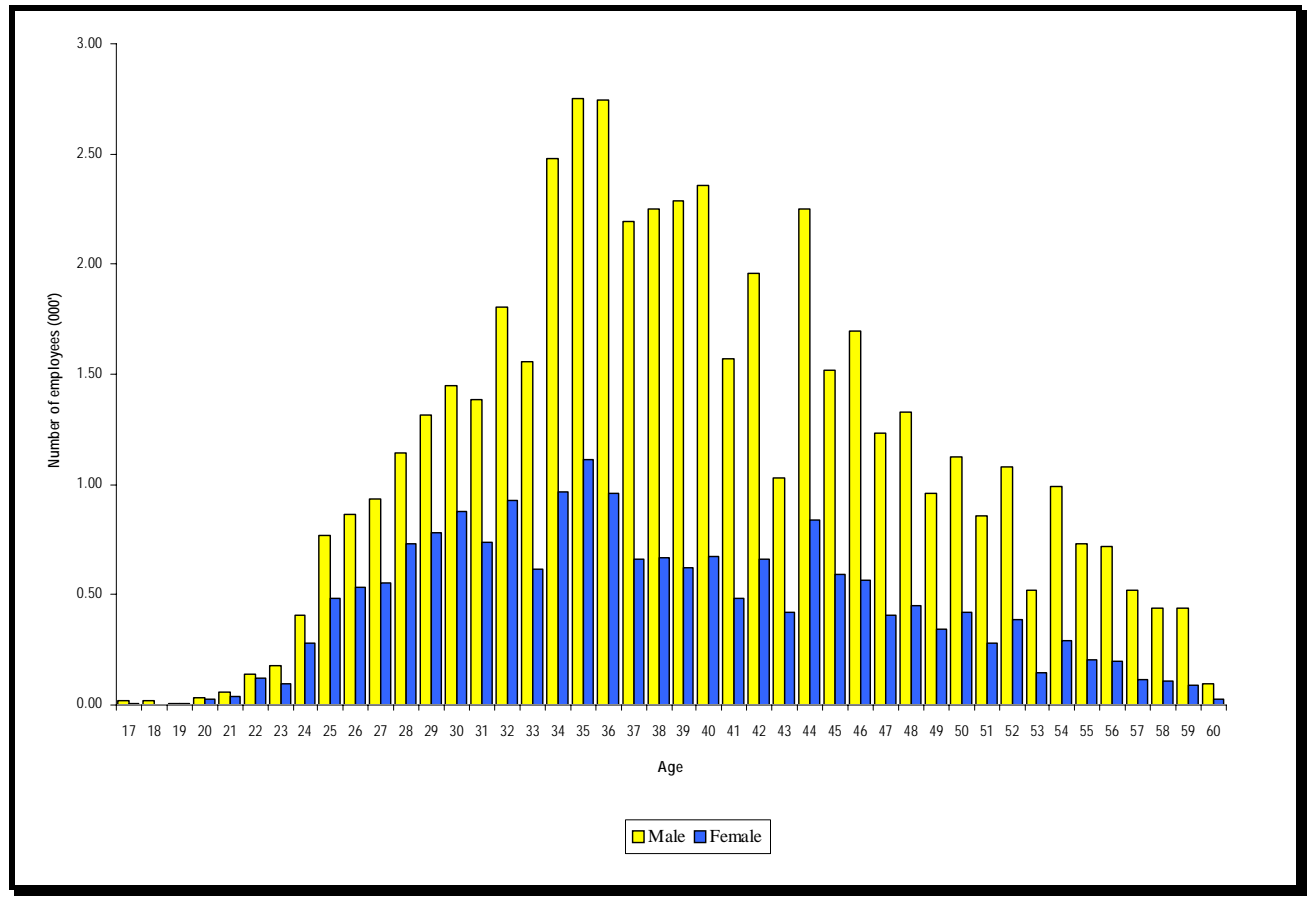

Notes: * Age distribution of civil servants (2003/2004)

Source: MOFPED

Figure 2: More than $30 \%$ of all teachers are women between the ages of 17 and $60 *$

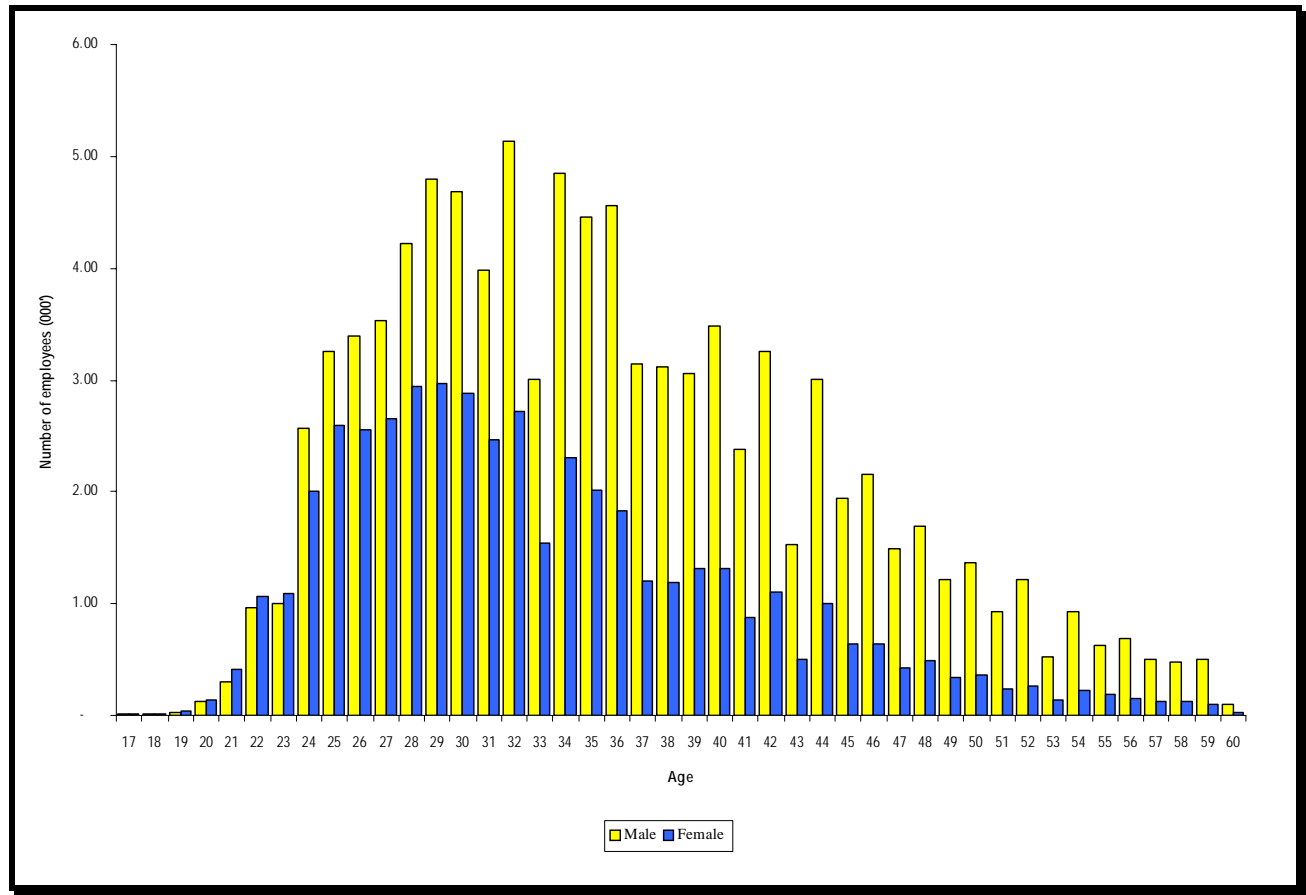

Notes: * Age distribution of teachers (2003/04).

Source: MOFPED. 
The age distribution of teachers is more skewed to the left hand side than the age distribution for civil servants for both genders telling us that on average teachers are younger than civil servants. The average age of teachers is 35 years (36 men and 33 women) while the average age for civil servants is 39 years (40 men and 38 women).

The age distributions of wages (Figure 3) for men and women in each of the two subschemes are very similar. However, on average civil servants tend to have higher wages than teachers in the same age and gender group. For modeling purposes the distributions were smoothed and assumed to be the same for both genders.

Figure 3: On average civil servants wages increase with age for both men and women *

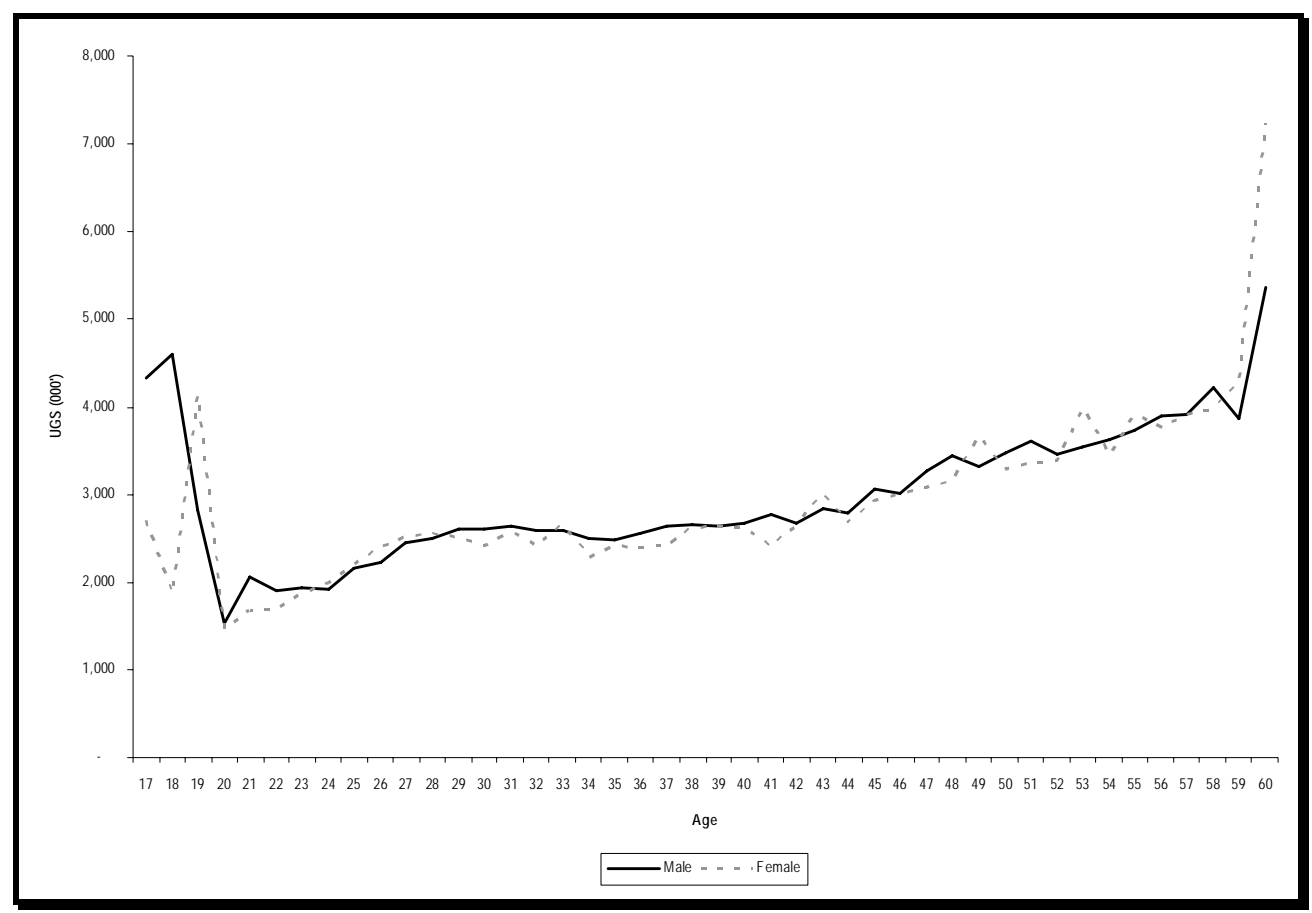

Notes: * Age and wage distribution for civil servants (2003/04).

Source: MOFPED. 
Figure 4: On average teacher wages slightly increase with age for both men and women

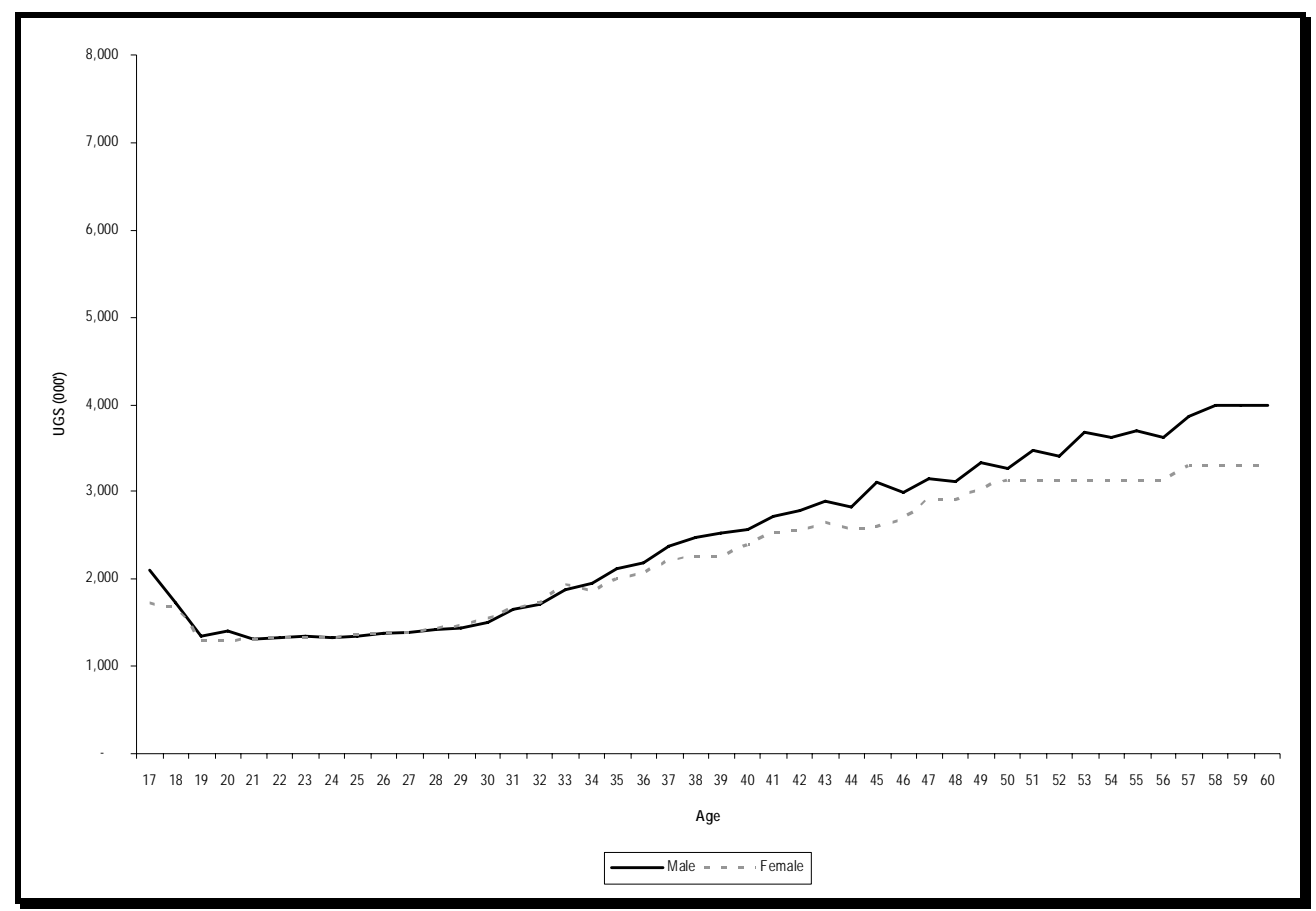

Notes: * Age and wage distribution for teachers (2003/04).

Source: MOFPED.

\section{III.C Information on the stock of retirees}

The total number of beneficiaries in all categories is 15,813 and 11,567 for civil servants and teachers respectively. As previously mentioned, the individual records of the stock of beneficiaries did not specify who old-age pensioners were or who survivors were. An additional sample was used to separate pensioners by benefit category. The sample data were not segregated by gender and the age indicated in the records related to recipients of survivorship benefit referred to the age of the deceased employee/old age pensioner (not the survivor her/himself). All pensioners 45 years of age were assumed to be survivors. For pensioners older than 45 years, the share of survivors in each age cohort - derived from the sample - was assumed to be the same for men and women.

The number of survivors was estimated to be 2,292 among civil servants and 505 among teachers. Table 7 summarizes the estimated numbers of the stock of old age pensioners, their average age and pension for the base year of 2003/04. The number of active teachers is twice as large as the number of civil servants. However, the number of teacher retirees is somewhat smaller. This is due to the fact that the teachers sub-scheme is significantly younger following a recently introduced expansion in hiring policy. Teacher retirees are also on average slightly older than government retirees, and receive lower pensions due to their lower average wages. 
Table 7: Summary of data on the stock of old age pensioners (2003/04)

\begin{tabular}{|c|c|c|c|}
\hline & $2003 / 04$ & Civil Servant retirees & Teacher retirees \\
\hline \multirow{3}{*}{ ㅎㅇㅇ } & Men & 12.155 & 8.297 \\
\hline & Women & 1.367 & 2.765 \\
\hline & Total & 13.521 & 11.062 \\
\hline \multirow{3}{*}{ ¿ัष } & Men & 64.5 & 70.1 \\
\hline & Women & 62.6 & 68.0 \\
\hline & Total & 64.3 & 69.6 \\
\hline \multirow{3}{*}{ 宅 } & Men & $2,301.7$ & $1,945.3$ \\
\hline & Women & $1,801.1$ & $1,198.3$ \\
\hline & Total & $2,248.5$ & $1,758.6$ \\
\hline
\end{tabular}

Notes: /1 this includes only annuities from reduced and full pensions.

Source: MPS.

Age distributions for the stock of old age pensioners derived for the base year of 2003/04 are plotted in Figure 5 and Figure 6.

Figure 5: Almost $90 \%$ of government retirees are men between the ages of 42 and 90

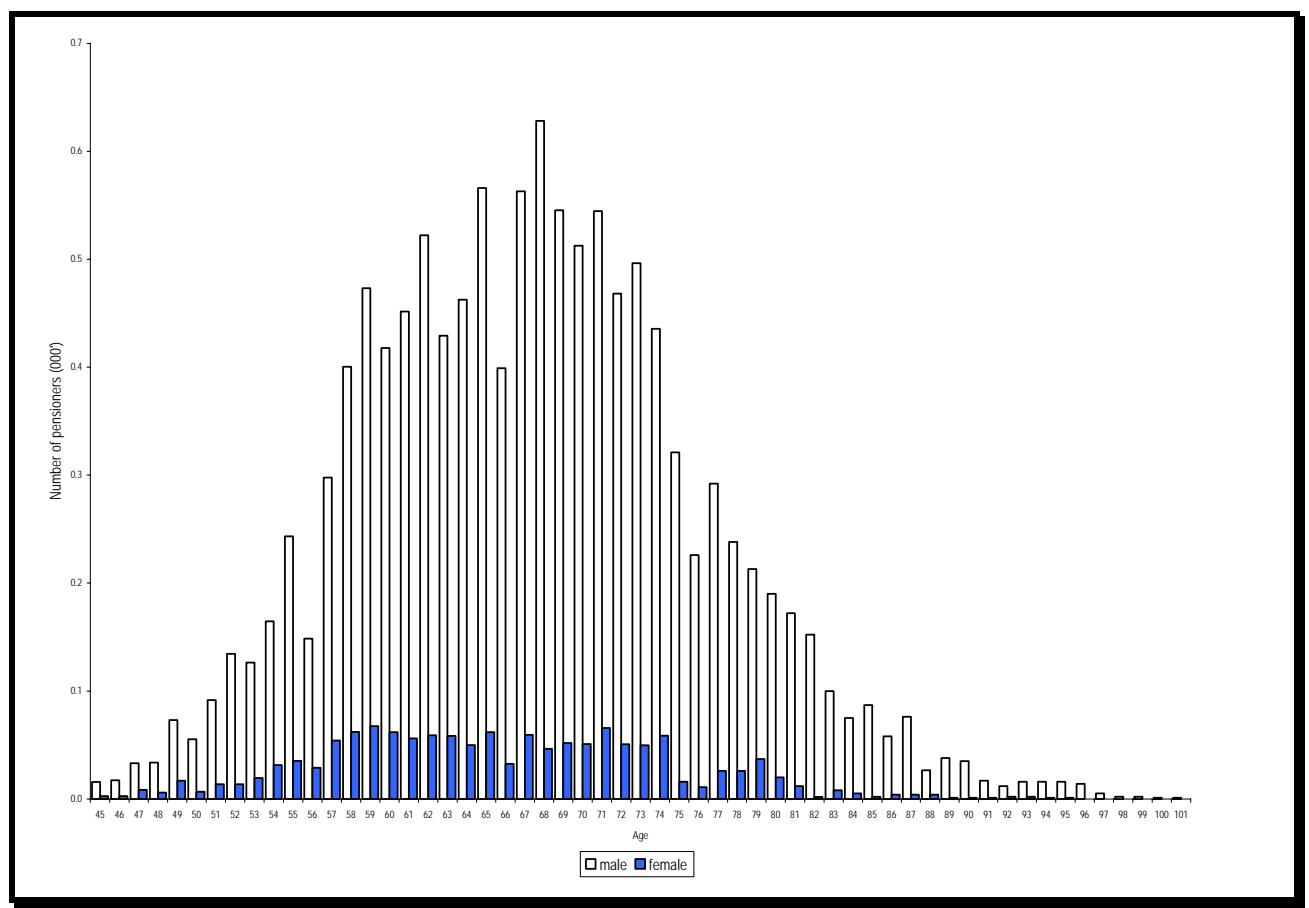

Notes: * Age distribution of civil servant retirees (2003/04).

Source: MPS. 
Figure 6: $72 \%$ of teacher retirees are men between the ages of 42 and 90*

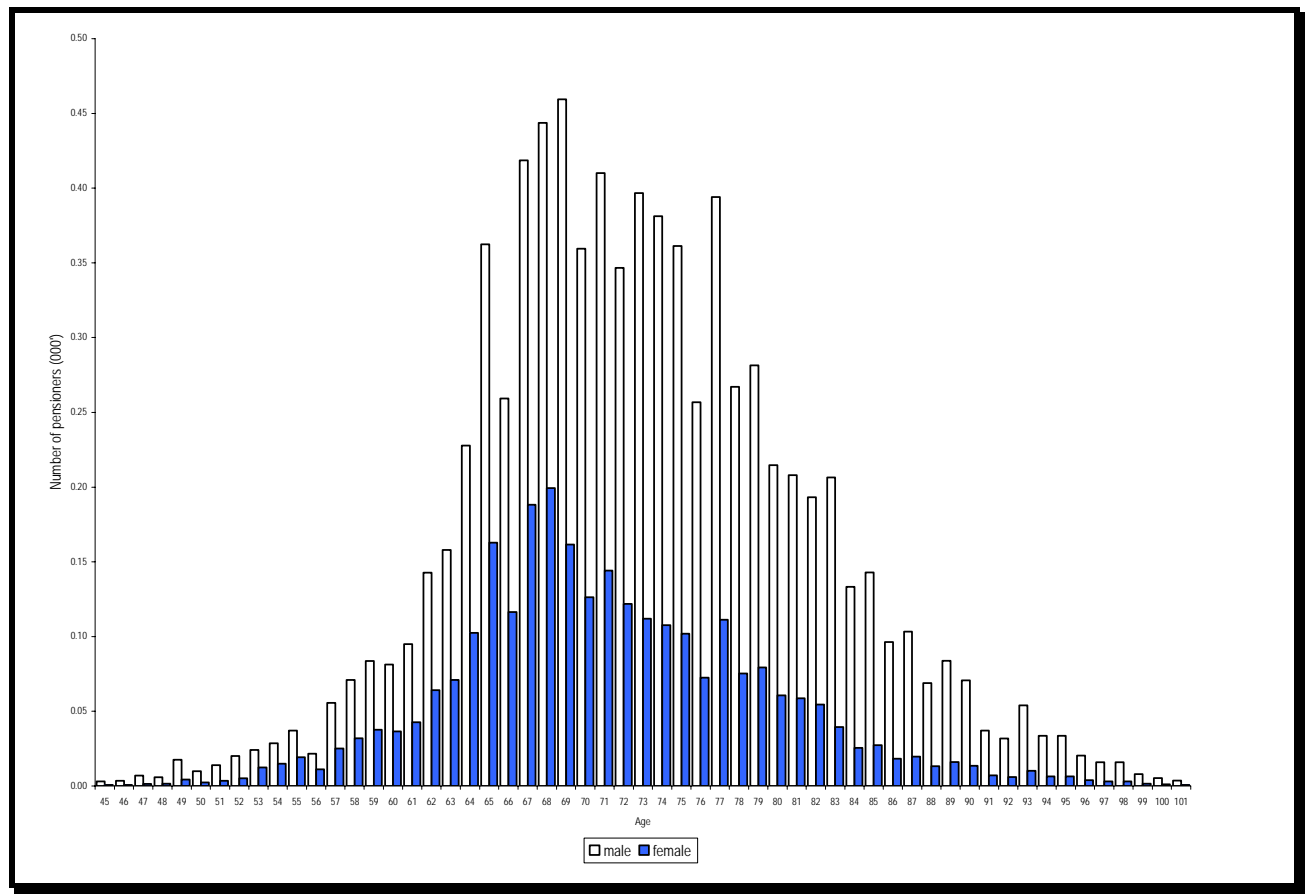

Notes: * Age distribution of teacher retirees (2003/04).

Source: MPS.

The gender distribution of both government and teacher retirees is more skewed than the gender distribution of respective active workers. The gender ratio is 2.6 men for every woman for active civil servants and 2 for teachers. The same ratios are 9 and 3 for government retirees and teachers, respectively. The skewed gender distribution is easily explained by the fact that, generally women do not accrue pensionable rights as they exit the labor market early for various reasons including marriage and household care. In Uganda, the marriage gratuity provided under CAP 286 contributes to explaining this gender skewness as, ceteris paribus, it promotes marriages. To some extent, this may also stem from growing labor force participation rates for women which is also widely observed in many developing countries.

Figure 7 shows the age and gender distributions of old age pensions for the stock of retirees derived from the database for the base year of 2003/2004. 
Figure 7: Age and gender distribution of the stock of civil servant retirees (2003/04, thous. persons)

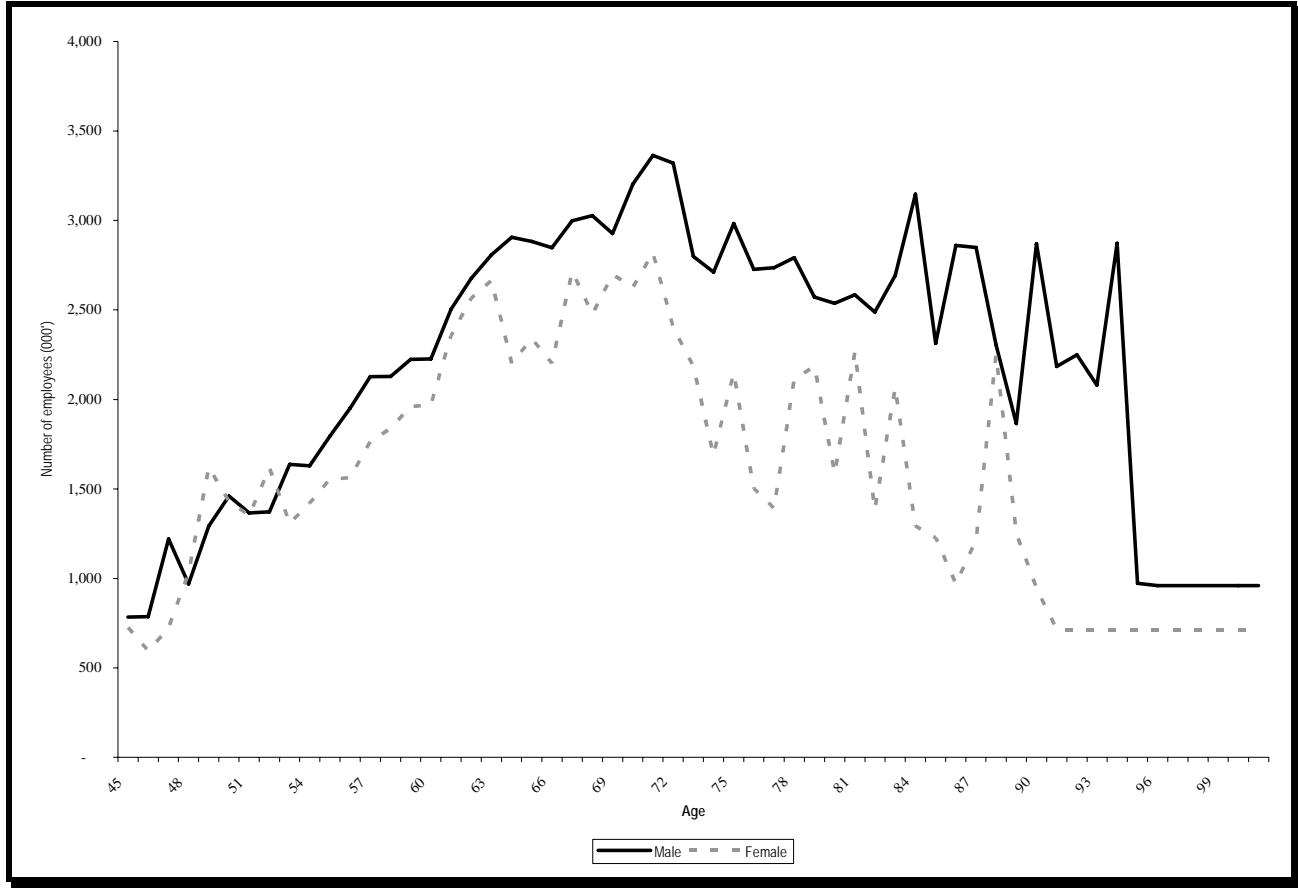

Source: MPS.

Figure 8: Age and gender distribution of the stock of teacher retirees (2003/04, thous. persons)

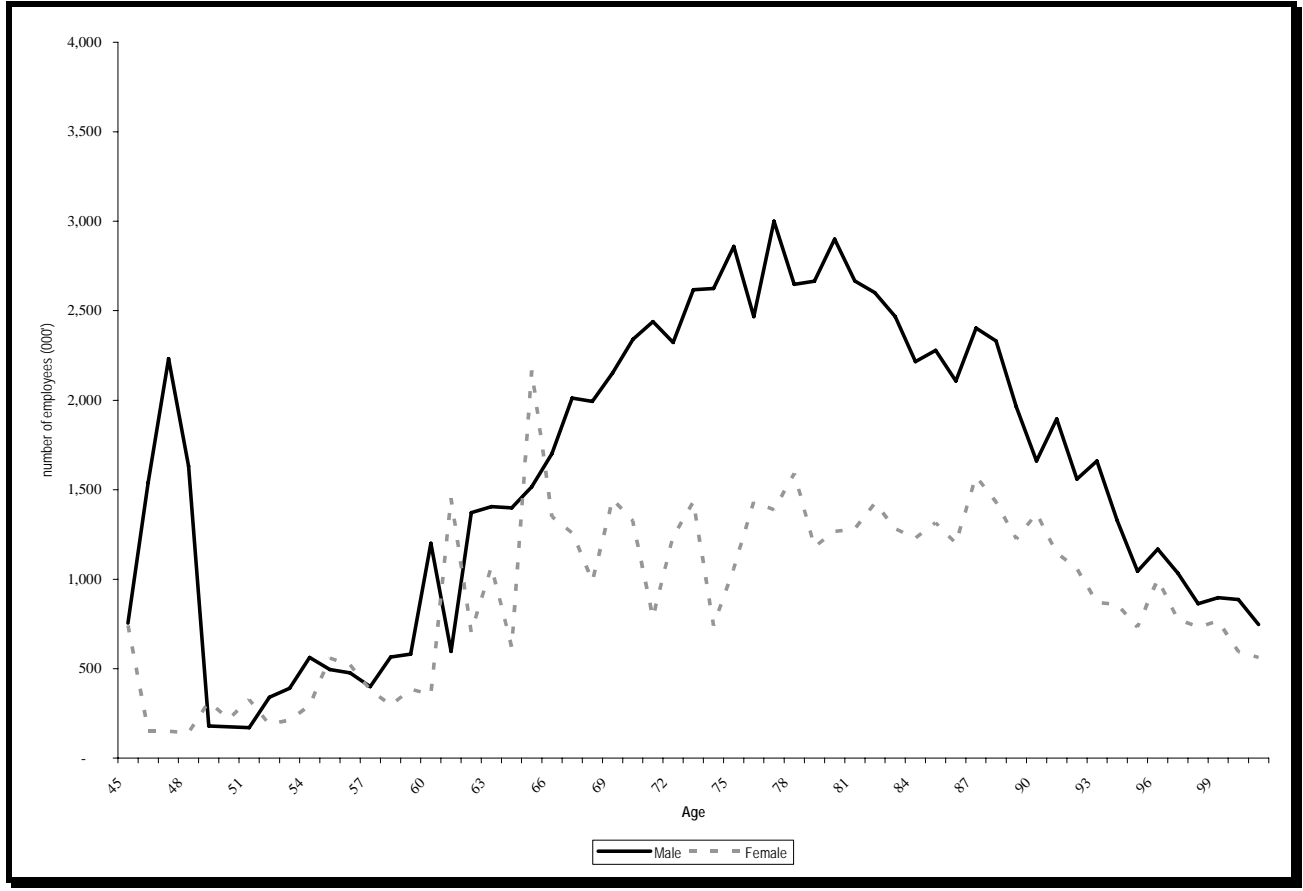

Source: MPS. 


\section{III.D Estimated key indicators for 2003/2004}

Table 8 reports the main pension indicators estimated for the base year 2003/2004. The indicators are derived from the data provided by our Ugandan counterparts. The total expenditure is calculated as what was due to system participants during the base year, without considering past arrears. ${ }^{7}$

Table 8: Main pension system indicators (2003/04)

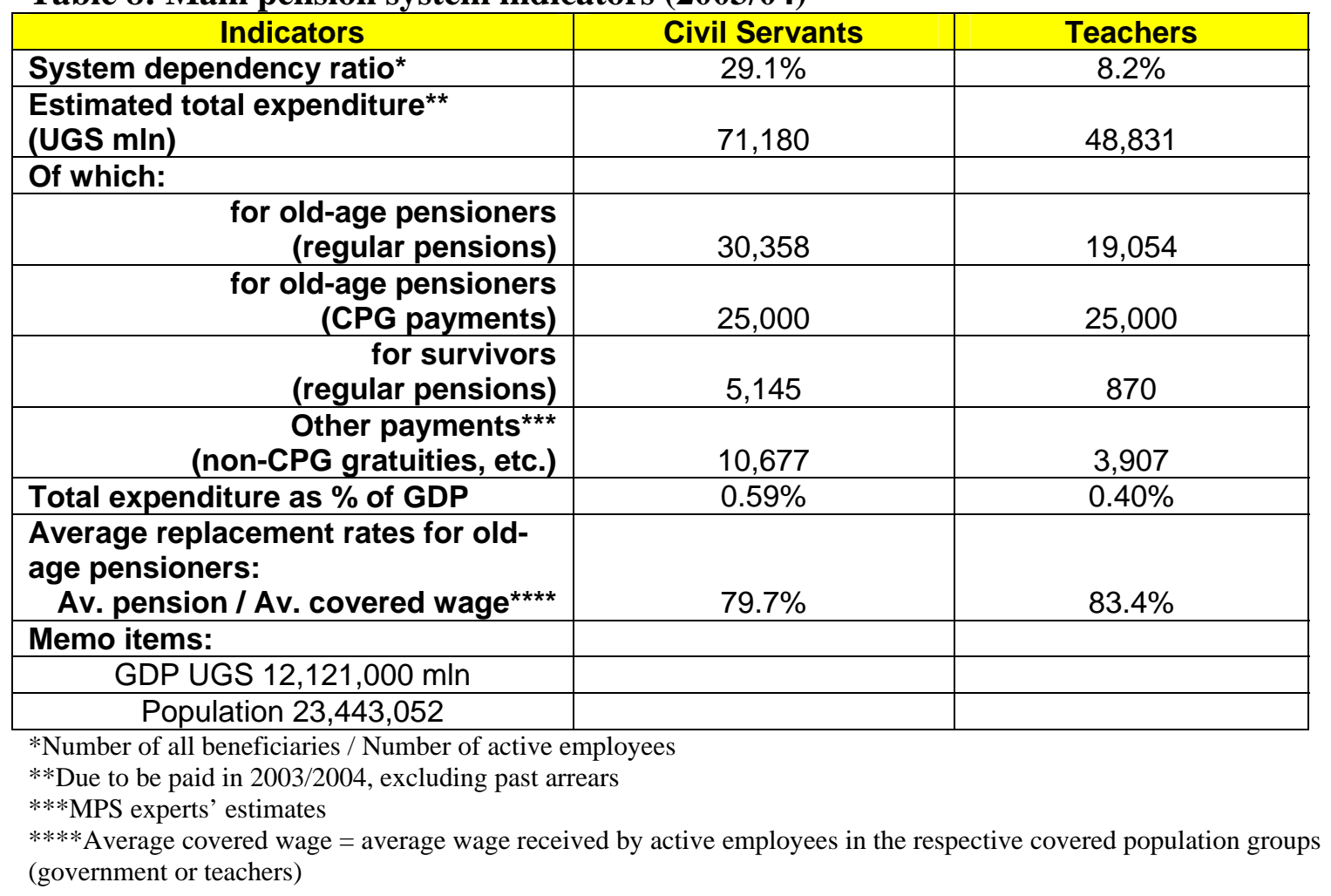

\section{THE BASELINE PROJECTIONS}

The analysis of the long term sustainability of a pension system involves assessing the adequacy of the pension promise defined in legal provisions and the cost associated with these pension promises. As far as adequacy of benefits is concerned, replacement rates in terms of average wage provide a useful measure of what individuals may expect to receive when they retire. As far as system costs are concerned, key benchmarks would be the time path of system expenditure, the contribution rate required to balance the system if the system were contributory, the financing gap (as an overall measure of system future liabilities), and the implicit pension debt (liabilities accrued by the system at a given point in time).

Apart from the generosity of benefits, the cost of the system is largely driven by the system demographics summarized in the system dependency rate.

\footnotetext{
${ }^{7}$ We have previously mentioned, but it is worth repeating it, that pension arrears do not affect our projections as the totality of new retirees elects to receive the reduced pension which is paid in full.
} 


\section{IV.AProjected system dependency rate}

The system dependency rate - a ratio of the total number of beneficiaries to the total number of active members - is largely determined by assumptions on coverage, retirement rates and mortality rates outlined in APPENDIX A. We argue that the use of country population mortality assumptions for civil servants may not be appropriate given the fact that in many countries, civil servants live on average longer than the general population. However, we could not confirm this with Ugandan demographers due to the lack of population specific mortality tables in the country. In order to allow for such assumption of higher longevity among civil servants, we constructed two baseline scenarios and called them "variant 1" and "variant 2". Essentially, "variant 2" makes allowance for longer life expectancy of civil servant populations while "variant 1 " uses the population mortality table.

Figure 9 compares the system dependency rates projected using general population civil servant mortality assumptions. In "variant 2", longer life expectancy for system participants in retirement causes an increase in dependency ratios by increasing the number of beneficiaries in each year.

Figure 9: Projections of civil servant dependency rates* under two alternative mortality assumptions

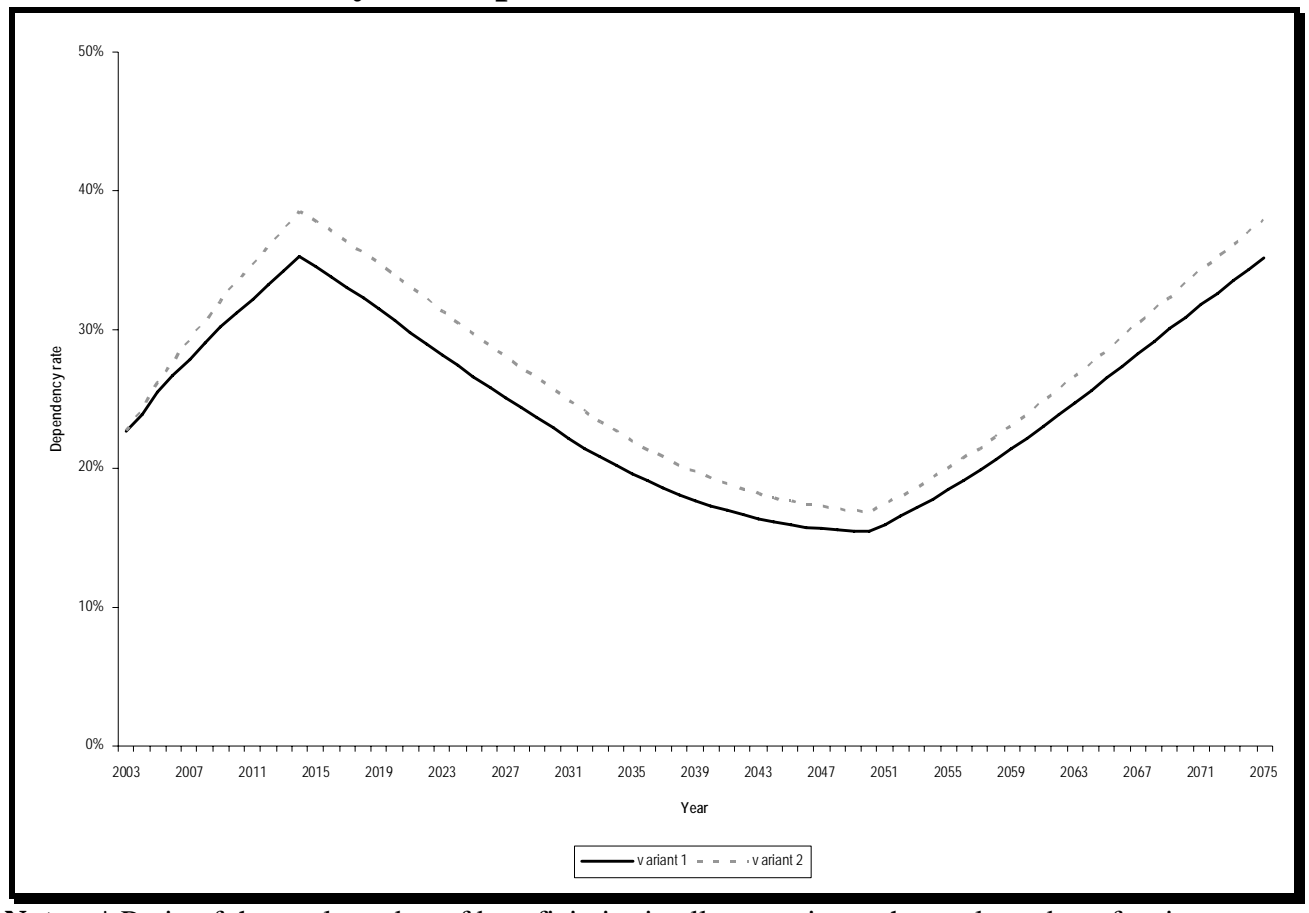

Notes: * Ratio of the total number of beneficiaries in all categories to the total number of active employees.

Source: WB calculations based on PROST 
Figure 10: Projections of teacher dependency rates* under two alternative mortality assumptions show an increase, particularly starting in 2050

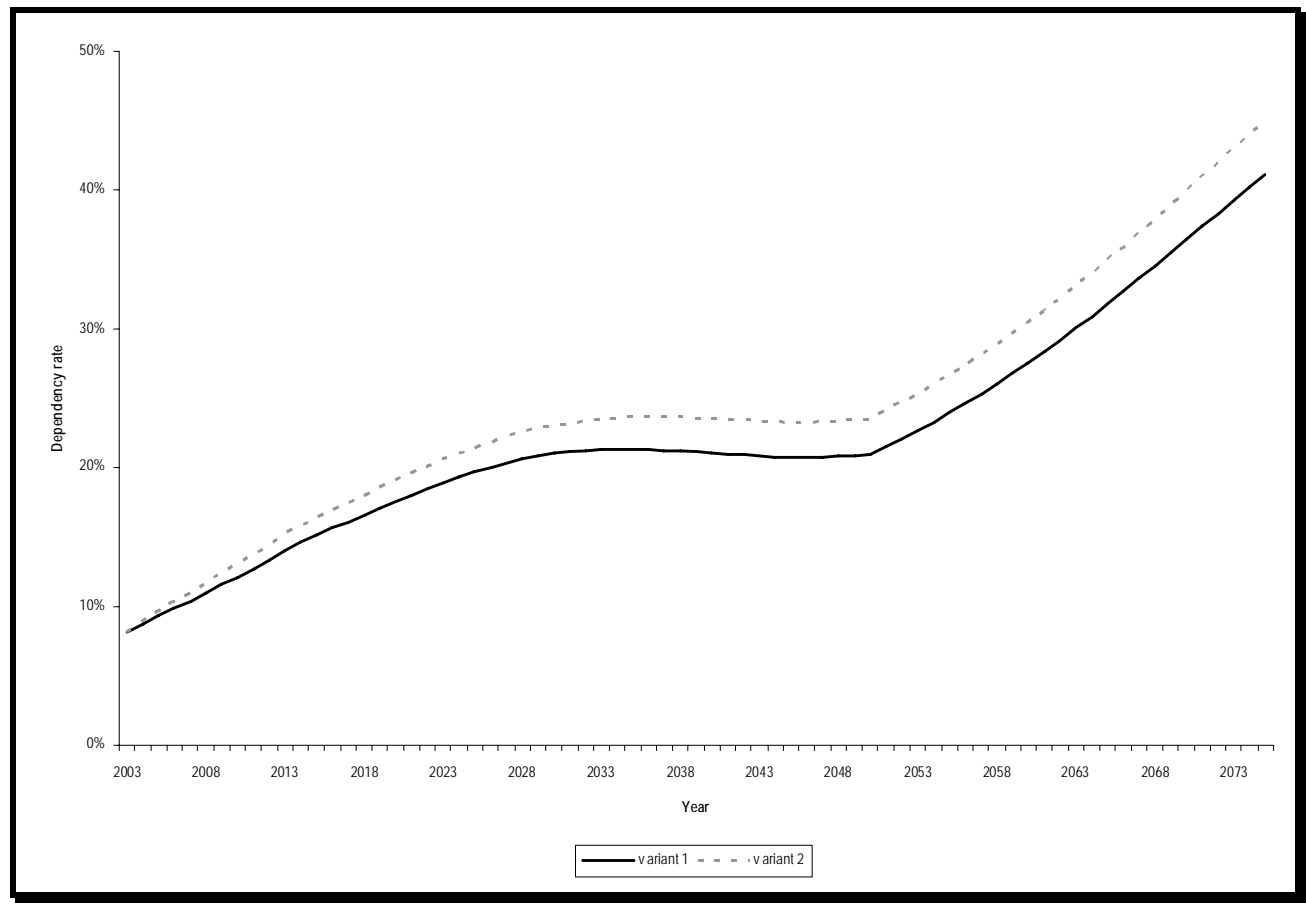

Notes: * Ratio of the total number of beneficiaries in all categories to the total number of active employees.

Source: WB calculations based on PROST

The current dependency rate for teachers is $8 \%$ and much lower than the $23 \%$ rate for civil servants. This stems from the fact that the teachers' sub-scheme is a much younger scheme. In the future, three main periods can be clearly distinguished:

- 2004-2014 - very low growth rates in the number of employed under the Pay Reform Policy proposal;

- 2015-2050 - period of faster coverage expansion to reach $1 \%$ of population in each of the two sub-schemes;

- 2050-2075 - period of slowing down coverage growth to match general population growth rates.

During the first period the dependency rates in both sub-schemes increase as the growth of the number of active members is too slow (especially for civil servants) to offset the impact of ageing.

During the second period of accelerated growth the dependency rate decreases for civil servants and stabilizes for teachers. The difference between the two sub-schemes can be explained by the fact that the number of teachers is higher than the number of active civil servants and therefore, teachers require a lower rate of growth to reach the target $1 \%$ of 
general population. ${ }^{8}$ In addition, the younger sub-scheme for teachers ages more quickly than the more mature sub-scheme for civil servants.

Finally, the third period reverses to growing dependency ratios in both groups as coverage expansion substantially slows down.

Towards the end of the simulation period the dependency rates for civil servants reach $35 \%$ and $38 \%$ while for teachers they reach $41 \%$ and $45 \%$, under the two mortality assumption variants. If the simulation horizon were extended further, the system dependency rates would continue growing as cohorts joined the system during the period of accelerated growth retire in full.

\section{IV.B Projected benefits}

The eligibility conditions and benefits offered by the system are quite generous by international standards ${ }^{9}$ : people can retire early, starting from age 45 ; the vesting period is only 10 years; the annual accrual rate for a full pension is $2.4 \%$, and the individual's last wage (which is normally the highest wage) is used as a reference wage for benefit calculation (see Table 5 for details). For example, a full career male government employee retiring at age 60 with an average 35 years of service can expect a full pension of about $130 \%$ of the average group wage. Even under the assumption that everybody chooses a reduced pension (2/3 of full pension) and the CPG, the average pension for the stock of retirees remains quite high relative to the average group wage - at about $80 \%$ for civil servants and even above $80 \%$ for teachers. ${ }^{10}$

When looking at civil service pension schemes in middle and low income countries, the average annual accrual rate for a full pension is also around 2.4\%, particularly in East and South Asia, and most countries in North Africa and the Middle East. However, when looking at other African countries such as Benin, Burkina Faso, Burundi, Ivory Coast, Gabon, Madagascar, Mali, Mauritius, Nigeria, Senegal, and Togo, the accrual rate is certainly lower than $2.4 \%$, being in most cases $2 \%$ or less than $2 \%$. In fact, the only African country that might have a more generous civil service pension scheme than Uganda might be Cape Verde (Palacios, Whitehouse 2006).

The projected replacement rates for the stock of retirees are shown in Figure 11. These are relatively stable over time due to wage indexation. Notice that the replacement rates shown in Figure 11 are based only on the reduced ${ }^{11}$ pension since we assume everybody elects to receive the CPG at the time of retirement and a reduced pension as a regular payment. The CPG is modeled separately as a lump sum that old age pensioners receive at the moment of retirement.

\footnotetext{
${ }^{8}$ These rates are 3.2\% and 5.7\% for teachers and civil servants, respectively until 2050.

${ }^{9}$ See next paragraph, and Palacios, and Whitehouse, 2006.

${ }^{10}$ In each case the replacement rate is expressed in terms of the average wage for this particular group. Though replacement rates for teachers are normally higher, their pensions in money terms are on average lower than those of civil servants due to teachers' lower average wages.

${ }^{11}$ Restoration to full pension after 15 years in retirement is also modeled and taken into account in the projected replacement rates.
} 
Figure 11: Projected average replacement rates* for the stock of retirees (reduced pension only) are decreasing over time

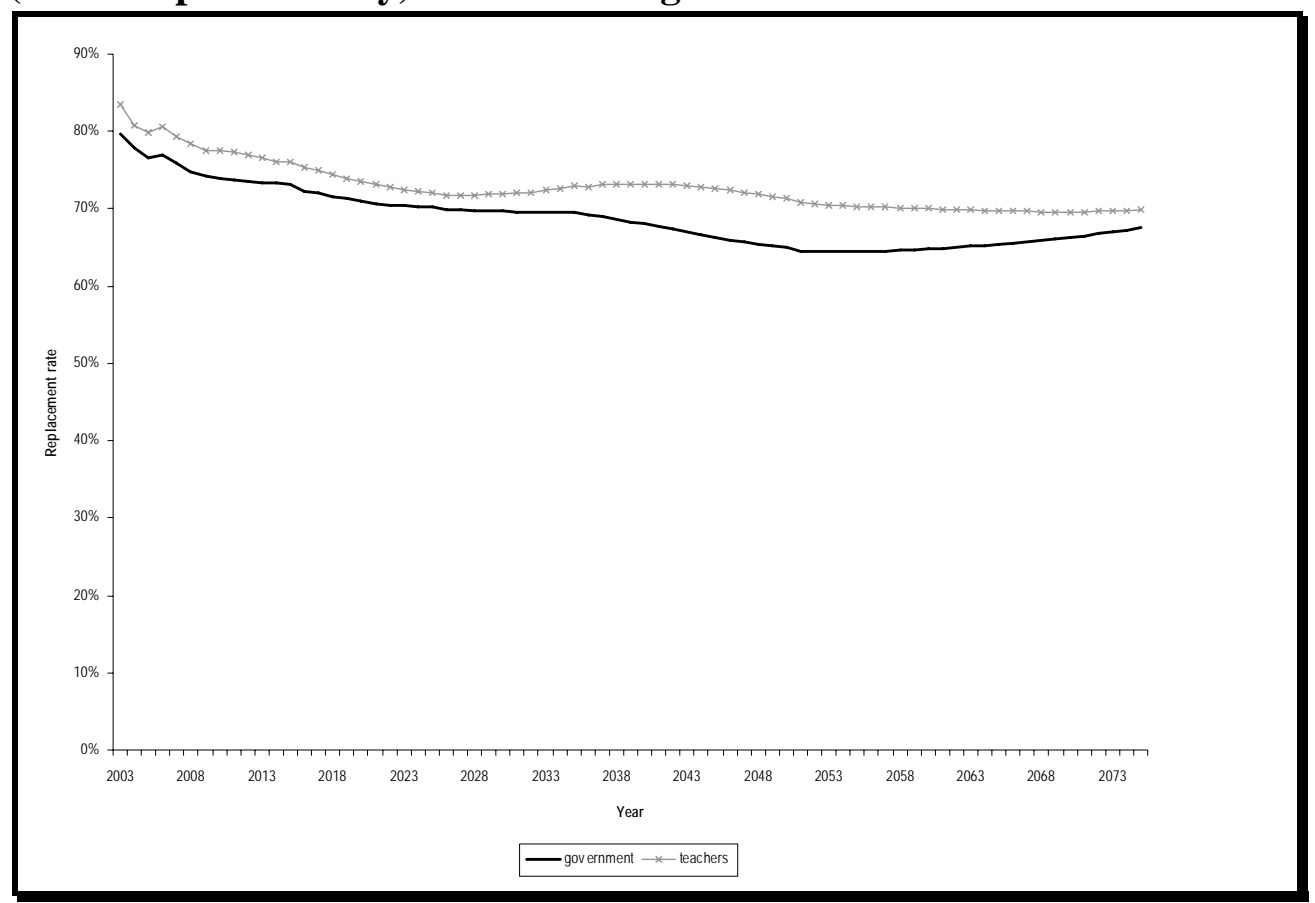

Notes: Average pension as \% of the group average wage. These replacement rates relate to reduced pension only. If CPG is included, replacement rates are higher than full pension replacement rates due to the fact that CPG calculations are more than actuarially fair. A 40 year career individual would retire with almost $100 \%$ of his/her final salary as full pension. Total replacement rates based on average salary exceed $100 \%$.

Source: WB calculations based on PROST

\section{IV.CProjected system expenditure}

For the projections, pension expenditure is estimated on the basis of the provisions contained in CAP 286, irrespectively of potential delays in payment due to administrative or budgetary issues. ${ }^{12}$ The projected pension expenditure in the future (under the assumption of no reform) is illustrated in Figure 12.

Under the assumption that life expectancy for the covered group is not different from the general population (variant 1 of the baseline scenario), total pension expenditure ${ }^{13}$ for both sub-schemes is expected to increase from the current 1\% of GDP to $1.9 \%$ around the year 2050, and further to $4.5 \%$ by the end of the simulation period. The steady growth of system pension expenditure relative to GDP is driven by several factors including assumed coverage expansion, wages growing more quickly than GDP per capita, and growing dependency rates.

If mortality rates for civil servant retirees are substantially lower (variant 2), clearly pension expenditure increases more quickly as the number of old age pensioners receiving benefits in each year increases. Under variant 2 , the total system expenditure is projected to grow to $2.1 \%$ by 2050 and further $4.8 \%$ by 2075 .

\footnotetext{
${ }^{12}$ Again, ignoring arrears does not have an impact on our projections. These are based on the reduced pension in the base year that is fully paid.

${ }^{13}$ Including pensions to all beneficiaries, lump-sum payments to all beneficiaries, gratuities, etc.
} 
Figure 12: Projected pension expenditure for civil servants (\% of GDP) is quite constant but exponentially increasing starting around 2040

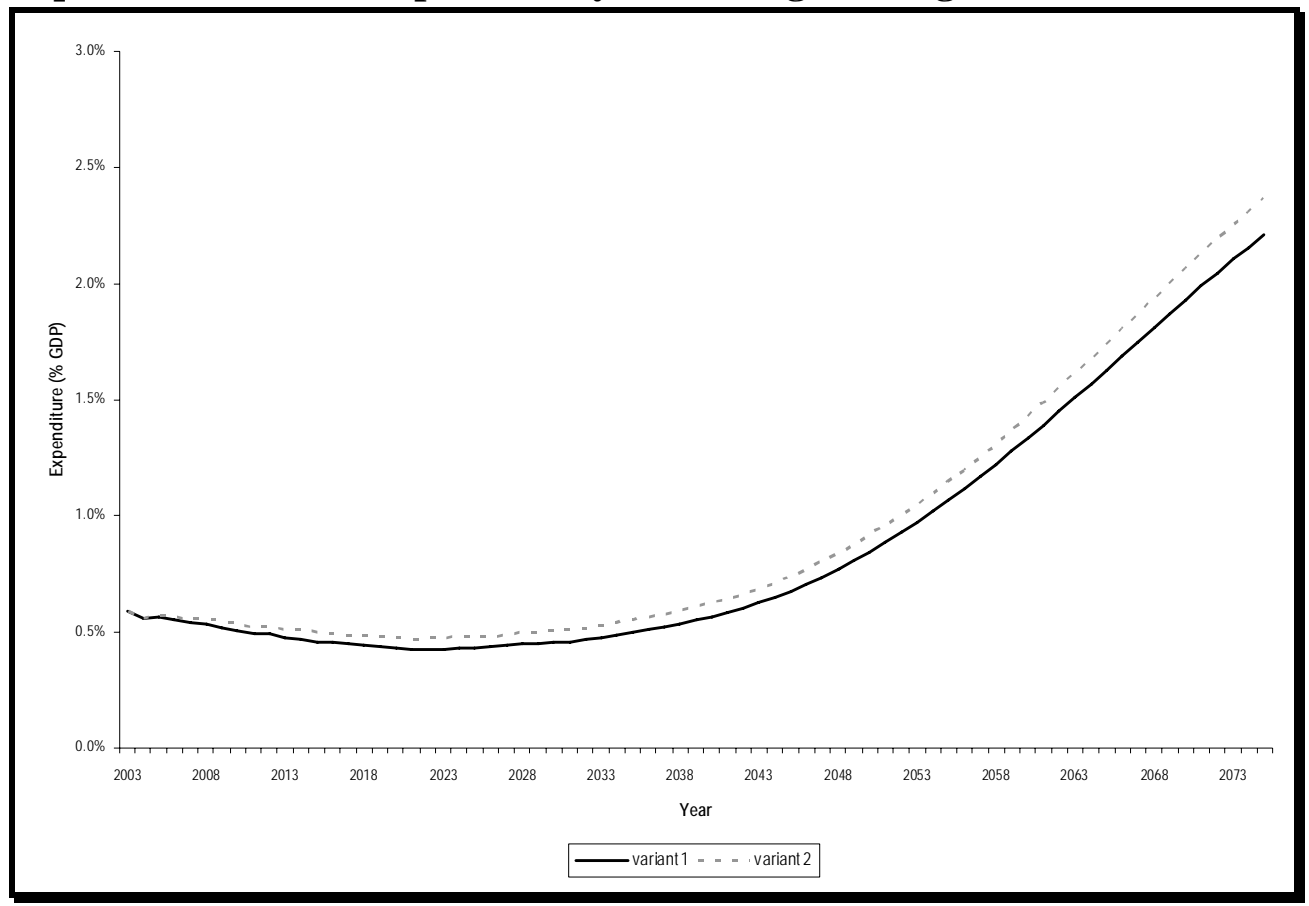

Source: WB calculations based on PROST

Figure 13: Projected pension expenditure for teachers (\% of GDP) is only increasing during the entire simulation period

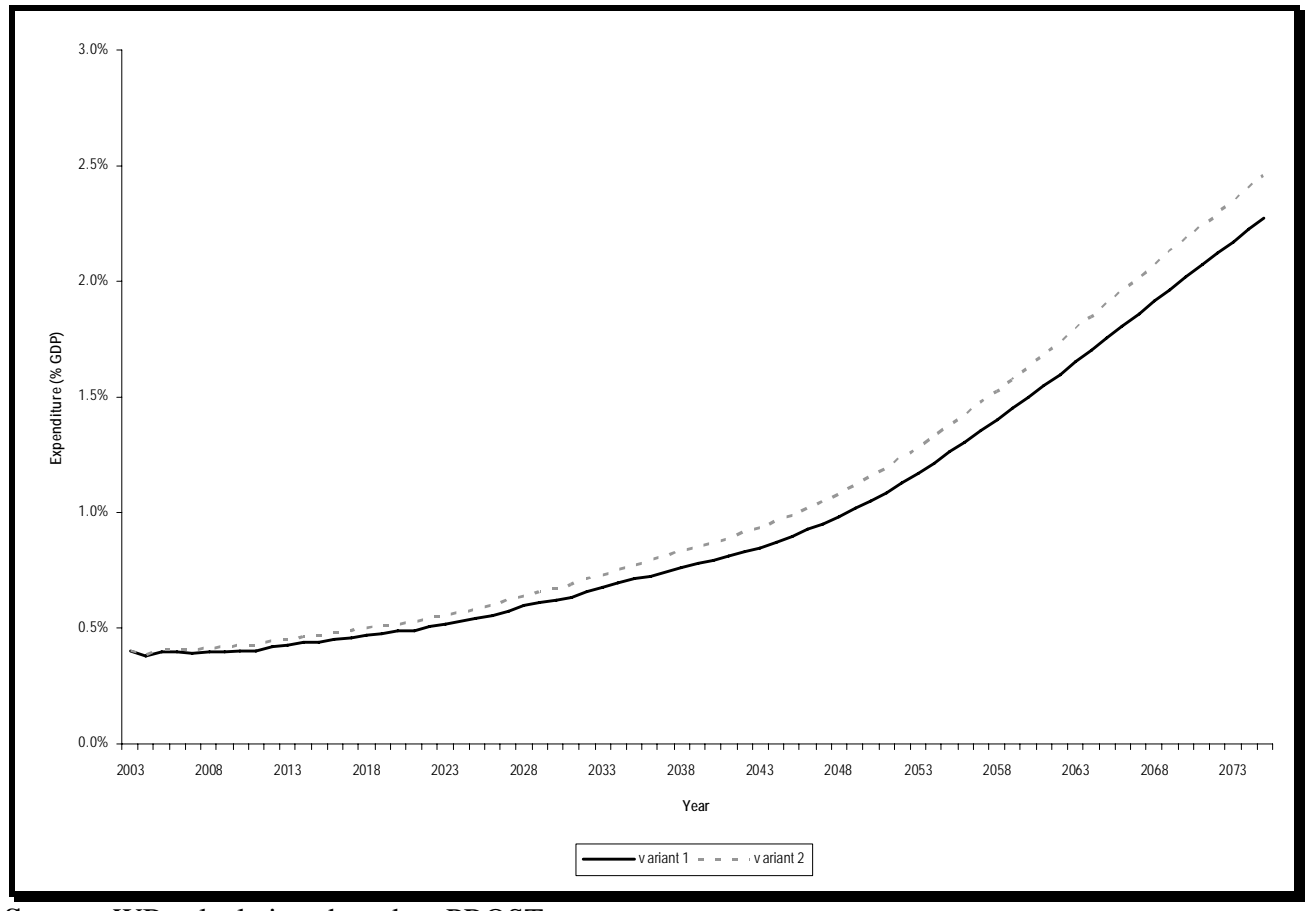

Source: WB calculations based on PROST 
Table 9 below provides a break down of the projected expenditure by major cost categories for the main baseline variant 1 (assuming general population mortality rates apply to the covered population).

Table 9: Projected total pension expenditure (baseline: variant 1)

\begin{tabular}{|c|c|c|c|c|c|c|}
\hline Year & $2003 / 04$ & $2004 / 05$ & $2005 / 06$ & $2020 / 21$ & $2050 / 51$ & $2075 / 76$ \\
\hline \multicolumn{7}{|l|}{ (In Million Shs, nominal) } \\
\hline Total pension expenditures & 126,026 & 133,089 & 149,552 & 575,191 & $10,638,752$ & $137,492,853$ \\
\hline \multicolumn{7}{|l|}{ Teachers } \\
\hline Regular pensions & 19,924 & 22,905 & 26,791 & 165,623 & $3,386,972$ & $43,950,374$ \\
\hline of which old age & 19,055 & 21,964 & 25,754 & 161,967 & $3,322,487$ & $43,452,673$ \\
\hline survivors & 870 & 941 & 1,037 & 3,656 & 64,485 & 497,701 \\
\hline Lump-sum payments (CPGs) & 25,000 & 24,443 & 27,534 & 103,990 & $1,730,532$ & $17,963,356$ \\
\hline Other expenditures & 4,776 & 5,058 & 5,761 & 27,101 & 509,485 & $5,881,504$ \\
\hline \multicolumn{7}{|l|}{ Traditional Civil Servants and Local G.S. } \\
\hline Regular pensions & 35,503 & 39,488 & 44,051 & 157,492 & $2,592,485$ & $40,692,922$ \\
\hline of which old age & 30,358 & 34,000 & 38,237 & 139,513 & $2,072,755$ & $36,500,046$ \\
\hline survivors & 5,145 & 5,488 & 5,814 & 17,979 & 519,730 & $4,192,877$ \\
\hline Lump-sum payments (CPGs) & 25,000 & 24,429 & 27,053 & 63,932 & $1,225,743$ & $14,986,110$ \\
\hline Other expenditures & 15,822 & 16,767 & 18,362 & 57,054 & $1,193,535$ & $14,018,588$ \\
\hline GDP & $12,121,000$ & $13,529,291$ & $14,870,991$ & $60,443,332$ & $530,418,048$ & $2,962,347,008$ \\
\hline \multicolumn{7}{|l|}{ (As $\%$ of GDP) } \\
\hline Total pension expenditures & $1.04 \%$ & $0.98 \%$ & $1.01 \%$ & $0.95 \%$ & $2.01 \%$ & $4.64 \%$ \\
\hline \multicolumn{7}{|l|}{ Teachers } \\
\hline Regular pensions & $0.16 \%$ & $0.17 \%$ & $0.18 \%$ & $0.27 \%$ & $0.64 \%$ & $1.48 \%$ \\
\hline of which old age & $0.16 \%$ & $0.16 \%$ & $0.17 \%$ & $0.27 \%$ & $0.63 \%$ & $1.47 \%$ \\
\hline survivors & $0.01 \%$ & $0.01 \%$ & $0.01 \%$ & $0.01 \%$ & $0.01 \%$ & $0.02 \%$ \\
\hline Lump-sum payments (CPGs) & $0.21 \%$ & $0.18 \%$ & $0.19 \%$ & $0.17 \%$ & $0.33 \%$ & $0.61 \%$ \\
\hline Other expenditures & $0.04 \%$ & $0.04 \%$ & $0.04 \%$ & $0.04 \%$ & $0.10 \%$ & $0.20 \%$ \\
\hline \multicolumn{7}{|l|}{ Traditional Civil Servants and Local G.S. } \\
\hline Regular pensions & $0.29 \%$ & $0.29 \%$ & $0.30 \%$ & $0.26 \%$ & $0.49 \%$ & $1.37 \%$ \\
\hline of which old age & $0.25 \%$ & $0.25 \%$ & $0.26 \%$ & $0.23 \%$ & $0.39 \%$ & $1.23 \%$ \\
\hline survivors & $0.04 \%$ & $0.04 \%$ & $0.04 \%$ & $0.03 \%$ & $0.10 \%$ & $0.14 \%$ \\
\hline Lump-sum payments (CPGs) & $0.21 \%$ & $0.18 \%$ & $0.18 \%$ & $0.11 \%$ & $0.23 \%$ & $0.51 \%$ \\
\hline Other expenditures & $0.13 \%$ & $0.12 \%$ & $0.12 \%$ & $0.09 \%$ & $0.23 \%$ & $0.47 \%$ \\
\hline
\end{tabular}

Source: PROST output files

\section{IV.DRequired contribution rate}

The required contribution rate is an analytical indicator measuring the rate that contributors should pay on their covered wages (regardless of whether it is levied against the employee or employer - in this case the government) to balance the system, assuming the system expenditure is solely financed through contributions. It can be calculated for each year or as a sustainable contribution rate balancing the system over the whole simulation period. This is a useful measure of what the system would cost to contributors if it were contributory. 
In a defined benefit system, one of the key factors determining the required contribution rate is the system dependency rate so the projected time path for the required contribution rate (Figure 14) is consistent with that of the dependency rate (compare with Figure 9).

Figure 14: Required contribution rate needed to balance the scheme under two alternative mortality assumptions for civil servants

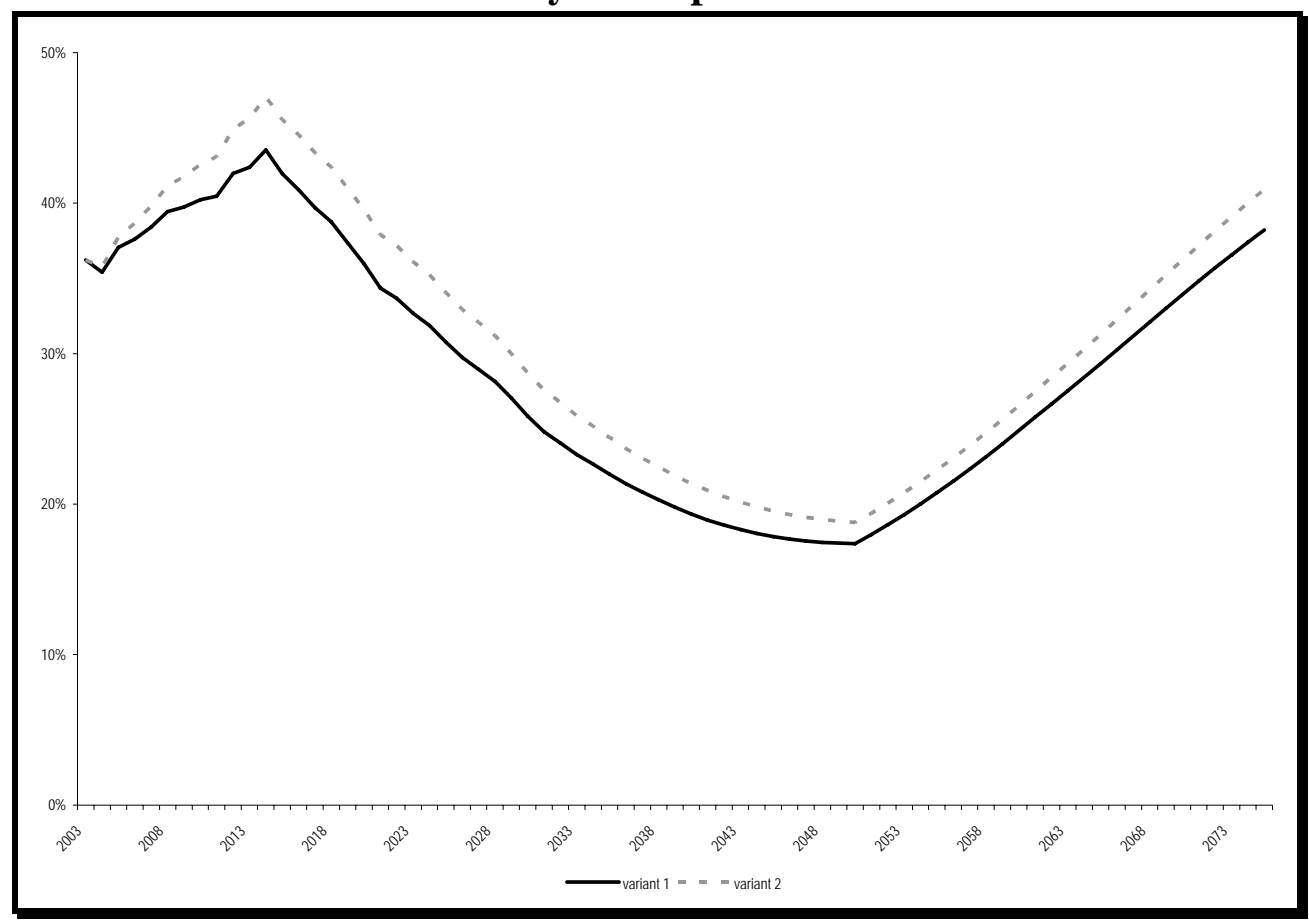

Source: WB calculations based on PROST 
Figure 15: Required contribution rate needed to balance the scheme under two alternative mortality assumptions for teachers

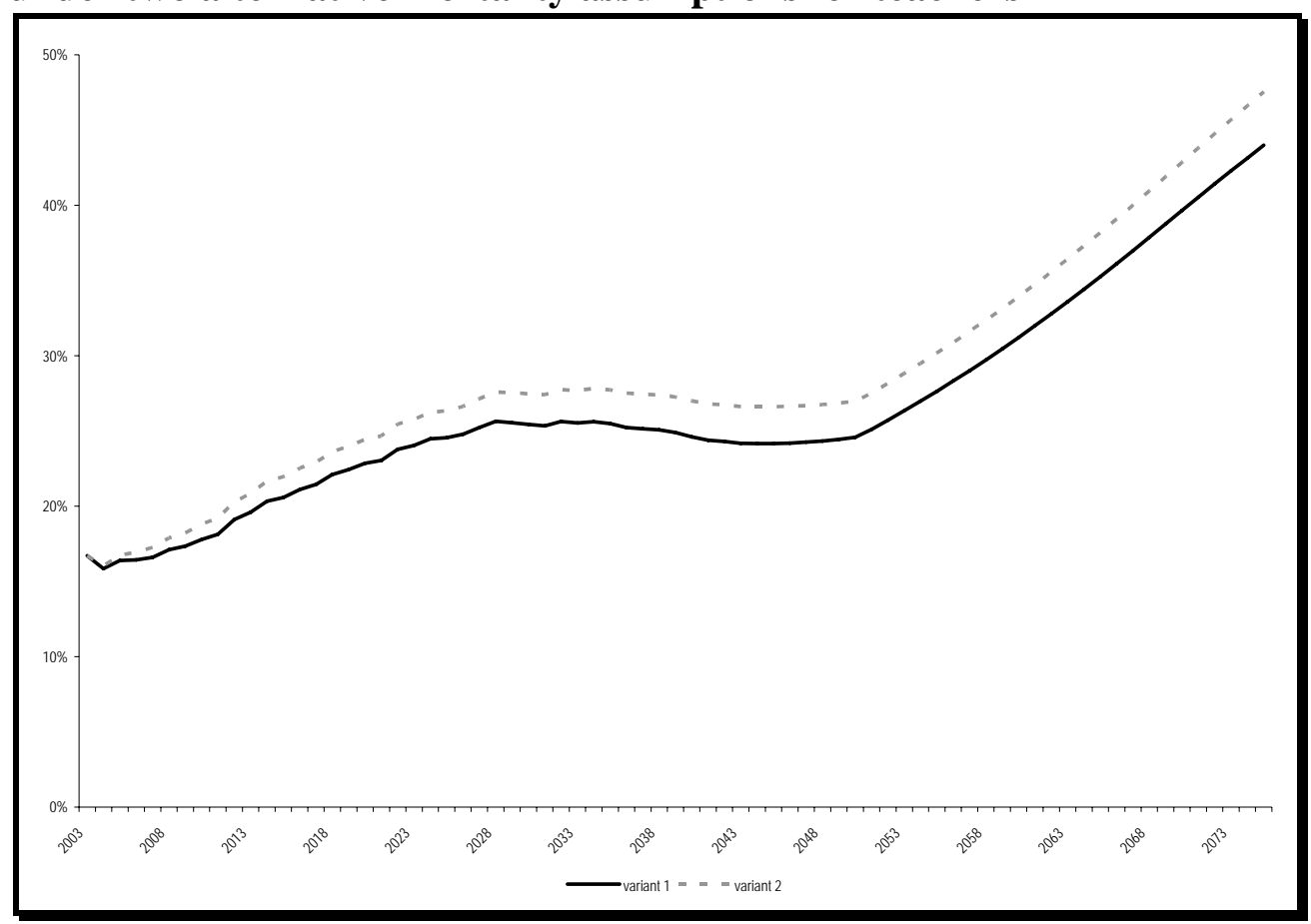

Source: WB calculations based on PROST

The required contribution rate for the civil servants sub-scheme starts from already a very high level of 36\% which would not be sustainable even in a developed economy. Over time, it increases, then down and then up again driven by the changes in the system dependency rate. It reaches its lowest level of $17 \%$ and $19 \%$ respectively, depending on the two mortality variants, by the end of the period of accelerated coverage expansion but only for few years. After 2050 the coverage expansion slows down, the dependency rate increases and as a result the required contribution rate also increases. Due to increasing system dependency rates over time, the required contribution rate for civil servants would be even higher than what is reported in the graph if the simulation period were extended.

In the teachers sub-scheme, the required contribution rate is initially much lower than for civil servants due to a much lower starting dependency rate. By the end of the simulation period the contribution rate required to balance the teachers sub-scheme exceeds the one projected for civil servants. For both civil servants and teachers, future changes in the required contribution rates mimic projected changes in the dependency rate.

An alternative indicator to the required contribution rate is the "sustainable contribution rate". This is an indicator conceptually very similar to the required contribution rate but it is defined as the fixed contribution rate that would balance the system over the whole simulation period. The sustainable contribution rate for civil servants is estimated at $30 \%$ and $31 \%$, depending on the two mortality variants. The sustainable contribution rate for teachers is estimated at $36 \%$ and $39 \%$, depending on the two mortality variants. 


\section{IV.E Implicit pension debt and financing gap}

In this study the implicit pension debt (IPD) is defined as the accrued-to-date liabilities and is calculated for each particular year as the present value of the benefits the pension system will have to pay to its current participants (active member and retirees) and their survivors on the basis of their pension rights accrued prior to this particular year. New pension rights earned after the year for which the IPD is calculated are not considered so this measure shows how much it would cost to discontinue the pension scheme and pay out all up to date obligations. ${ }^{14}$

This is a common indicator used by the international community and fiscal affairs experts when comparing the maturation and fiscal burden of different pension systems. It is important to note that this indicator is highly sensitive to the discount rate used in the calculation. The real discount rate used in the simulations for PSPF is quite high at 5\% which gives an estimate for the system IPD on a lower end. Varying the discount rate may be considered in further simulations.

Figure 16 illustrates the projected implicit pension debt for Uganda for both groups civil servants and teachers - under two sets of assumptions regarding life expectancy for the covered population (variants 1 and 2). For the base year, the total liabilities accrued by the system in both components are estimated at 23\% and 27\% of GDP respectively, depending on the variant. Liabilities are very large ${ }^{15}$ and they continue to build up over time reaching $100 \%$ and $110 \%$ of GDP towards the end of the simulation period. ${ }^{16}$ The population covered by PSPF increases from less than $1 \%$ to $2 \%$ of total population over the same period.

\footnotetext{
${ }^{14}$ The IPD calculated here is an approximation to the projected benefit obligation (PBO) concept used in the US literature.

${ }^{15}$ The discount rate used for IPD calculation is 5\% real. This is made to coincide with real rate of return on assets expected in the good state of the world in the reformed scheme. With a lower discount rate liabilities would be of course higher. The generous discount rate and the limited coverage of the scheme (less than $1 \%$ of Ugandan population) clearly indicate how liabilities are high by international standards.

${ }^{16}$ See APPENDIX C for IPD estimates conducted for some other countries.
} 
Figure 16: Projected implicit pension debt* for civil servants (\% of GDP) increases exponentially starting around 2030

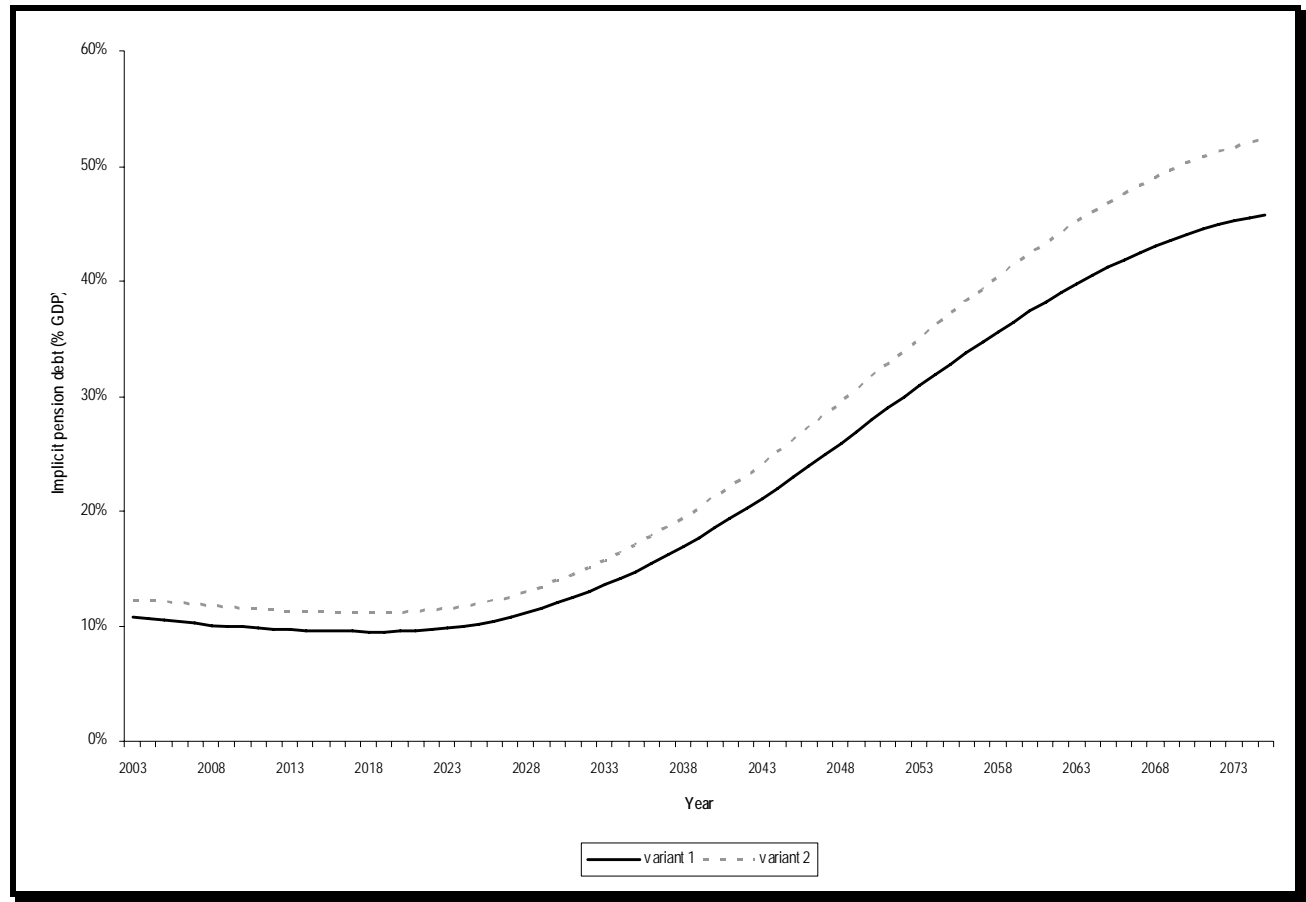

Notes: * liabilities accrued by the system at a given point in time

Source: WB calculations based on PROST

Figure 17: Projected implicit pension* debt for teachers (\% of GDP) only increases during the entire simulation period

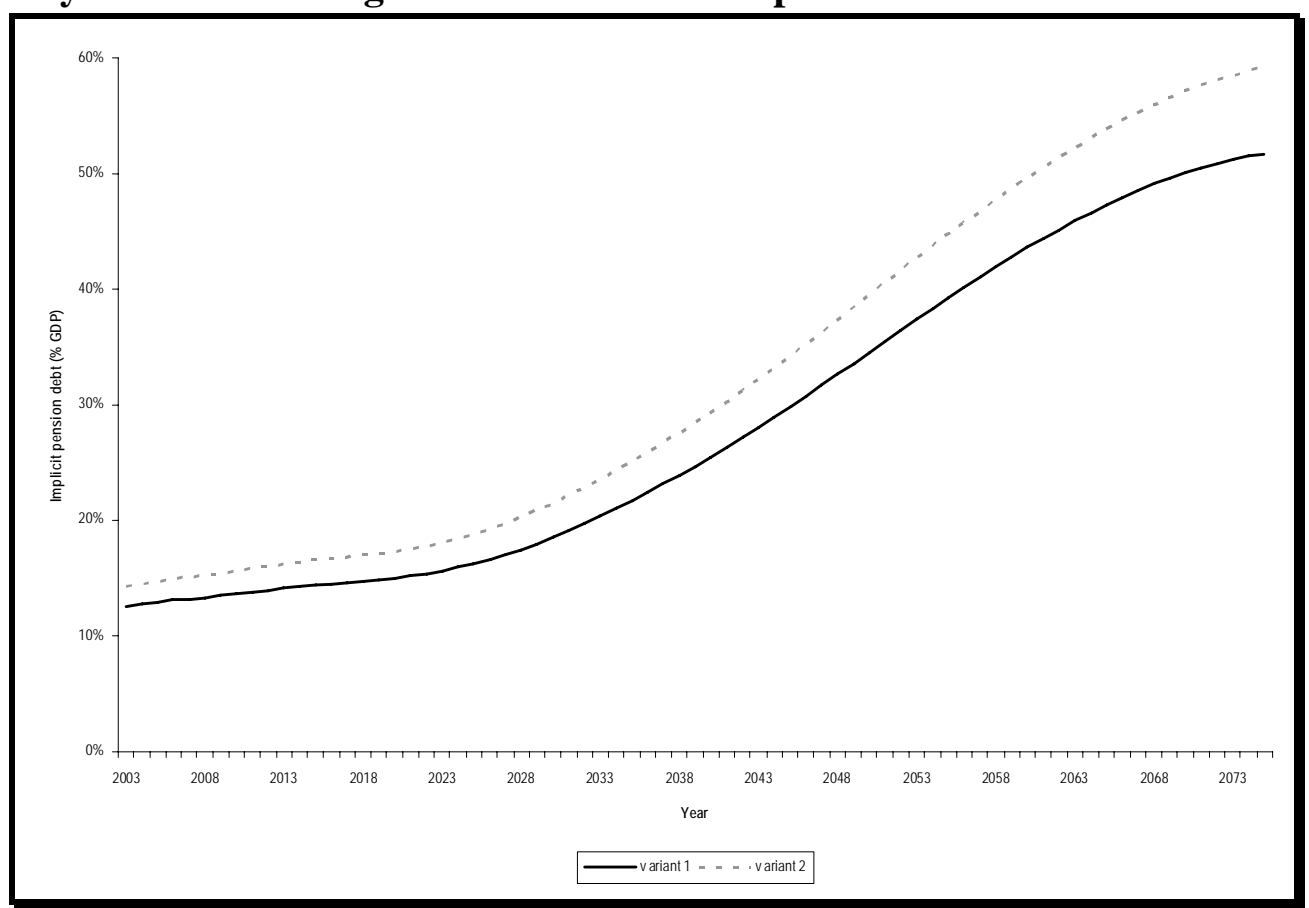

Notes: * liabilities accrued by the system at a given point in time Source: WB calculations based on PROST 
The financing gap is calculated as the present value of the projected system expenditure and measures the outstanding liabilities under the assumption that the system continues and all pension rights are taken into account - accrued-to-date as well as pension rights expected to be accrued by system participants in the future. Since the IPD, this measure is very sensitive to the assumed discount rate. As new pension rights are considered as well, normally the financing gap is larger than the IPD. For civil servants it is estimated at $53 \%$ and $57 \%$ of the base year GDP and for teachers at $60 \%$ and $65 \%$ for the two mortality variants, respectively. With the assumed accelerated coverage expansion throughout a substantial portion of the simulation period, these estimates do not capture the total payout period for those joining the system during this period and thus understate the liabilities. Also, the assumed relatively high 5\% real discount rate places these estimates on a lower end of the estimate range.

\section{IV.F The role of the recruitment assumptions in baseline projections}

The assumptions made regarding recruitments of new teachers and civil servants play a crucial role in driving many of the results obtained. Since recruitment assumptions are hard to predict over a long period of time, such as the one used for our simulations, it is worth discussing in brief the qualitative impact of alternative recruitment assumptions.

We have assumed that in the long run the populations of civil servants and teachers will reach $1 \%$ of the total population respectively. This specific assumption implies very favorable dependency rates over the medium to long term therefore, yielding acceptable required contribution rates, especially for civil servants. For instance, Figure 14 shows that the system for civil servants can remain unreformed and rebalanced by making it contributory with a $17 \%$ contribution rate. Once the $1 \%$ of the population target is reached and the recruitment policy slowed to match total population growth, the required contribution rate would start increasing rapidly underlying the maturity and generosity of the scheme.

It is straightforward to predict the qualitative changes in the results so far derived if we assume a lower growth in the covered population. For instance, we can compare the end of simulation period results in the main baseline described earlier in this section and the results of an alternative baseline. This is identical to the main baseline with the exception of a lower assumed growth rate in covered population. For this alternative baseline we have assumed the following:

1) From 2004/05 until 2014/15 recruitment policy is the same as in variant 1 (see Table 19).

2) From 2015/16 through the end of the simulation period teachers grow in line with the population growth and civil servants continue to grow at a constant $0.26 \%{ }^{17}$

Table 10 compares the end-of simulation period results of the main and alternative baseline scenarios. As one would expect, dependency rates in the alternative baseline are higher due to the faster aging of the covered population when fewer young workers enter the labor force every year. As one would expect, the replacement rates are about the

\footnotetext{
${ }^{17}$ As suggested by the medium-term active populations growth assumptions of Table 19.
} 
same. The pension expenditure as a percentage of GDP is lower in the alternative baseline as fewer workers would accrue pension benefits. However, due to the fact that fewer workers would pay for pension benefits, the required contribution rate would be higher in the alternative baseline. Finally, the implicit pension debt would be much lower in the alternative baseline reflecting smaller growth of covered population.

Table 10: The impact of lower covered population growth rates on end of simulation period results.

\begin{tabular}{|l|c|c|c|c|}
\hline \multirow{2}{*}{ Indicator } & \multicolumn{2}{|c|}{$\begin{array}{c}\text { Government } \\
\text { employees }\end{array}$} & \multicolumn{2}{c|}{ Teachers } \\
\hline & $\begin{array}{c}\text { Alternative } \\
\text { baseline }\end{array}$ & $\begin{array}{c}\text { Main } \\
\text { baseline }\end{array}$ & $\begin{array}{c}\text { Alternative } \\
\text { baseline }\end{array}$ & $\begin{array}{c}\text { Main } \\
\text { baseline }\end{array}$ \\
\hline Dependency rate & $56 \%$ & $35 \%$ & $45 \%$ & $41 \%$ \\
\hline $\begin{array}{l}\text { Replacement rate (reduced } \\
\text { pension only) }\end{array}$ & $69 \%$ & $68 \%$ & $72 \%$ & $70 \%$ \\
\hline Expenditure as \% of GDP & $0.5 \%$ & $2.2 \%$ & $1.5 \%$ & $2.3 \%$ \\
\hline Required contribution rate & $62 \%$ & $38 \%$ & $56 \%$ & $44 \%$ \\
\hline $\begin{array}{l}\text { Implicit pension debt as \% of } \\
\text { GDP }\end{array}$ & $8 \%$ & $46 \%$ & $29 \%$ & $52 \%$ \\
\hline
\end{tabular}

Source: WB calculations based on PROST.

\section{OPTIONS FOR REFORM}

Two reform options have been modeled as part of the study, with some variations within each reform scenario. In the first option the PSPF scheme is transformed into a provident fund (a scenario now being considered by the Government). We will further refer to this option as "Reform I". The second option entails transforming the PSPF scheme into a hybrid scheme with a small defined benefit component and a complementary mandatory defined contribution component. We will further refer to this reform option as "Reform II”. Both reforms substitute wage indexation of benefits with price indexation for switchers ${ }^{18}$.

A number of variations for each of each reform scenario have been modeled. The first pair of variations relates to the switching pattern of workers with accrued pension rights: we consider the two polar cases of immediate switching of all current workers to the reformed scheme and grandfathering of all workers with accrued rights in the unreformed scheme. In addition, in the provident fund reform option (reform I), we consider two cases of benefit indexation for non switchers: maintaining wage indexation or changing it to prices. In the case of the hybrid reform option we do not explore price indexation for non-switchers.

Another pair of meaningful variations involves assumptions regarding the interest rate earned on individual accounts. For each reform I and II we model two cases where assets are well managed or mismanaged.

Hence, seven cases will be analyzed in this section and they are labeled as follows:

\footnotetext{
${ }^{18}$ Here and further in the text switchers mean those individuals who switch to the reformed scheme and non switchers - those who stay in the unreformed scheme.
} 
An Assessment Of Reform Options For The Public Service Pension Fund In Uganda

Table 11: Alternative scenarios under the pure DC and hybrid reform options

\begin{tabular}{|c|c|c|}
\hline & & Scenarios \\
\hline & Baseline & Existing DB scheme \\
\hline \multirow{3}{*}{ 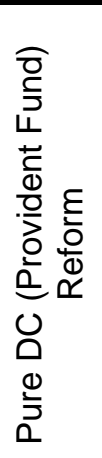 } & Reform I.1 & $\begin{array}{l}\text { Pure DC reform with immediate switching. Price indexation for switchers and } \\
\text { current retirees. } \\
\text { Variant I.1.A: high rate of return on assets } \\
\text { Variant I.1.B: low rate of return on assets }\end{array}$ \\
\hline & Reform I.2 & $\begin{array}{l}\text { Pure DC reform for only new entrants with wage indexation for grandfathered } \\
\text { employees and current retirees. Price indexation for switchers. Assumed } \\
\text { high rate of return on assets. }\end{array}$ \\
\hline & Reform I.3 & $\begin{array}{l}\text { Pure DC reform for only new entrants with price indexation for grandfathered } \\
\text { employees and current retirees. Price indexation for switchers. Assumed } \\
\text { high rate of return on assets. }\end{array}$ \\
\hline \multirow{2}{*}{ 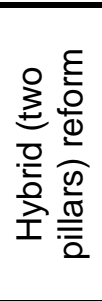 } & Reform II.1 & $\begin{array}{l}\text { Hybrid reform with immediate switching. Price indexation for switchers and } \\
\text { current retirees. Assumed high rate of return on assets. } \\
\text { Variant II.1.A: high rate of return on assets } \\
\text { Variant II.1.B: low rate of return on assets }\end{array}$ \\
\hline & Reform II.2 & $\begin{array}{l}\text { Hybrid reform for only new entrants with wage indexation for grandfathered } \\
\text { employees and current retirees. Price indexation for switchers. Assumed } \\
\text { high rate of return on assets. }\end{array}$ \\
\hline
\end{tabular}

Notice that in the hybrid reform (reform II) we do not model alternative benefit indexation for non switchers. The reason for this relates that non-switchers remain in the current unreformed system and are not affected by any reform scenario. Therefore, the impact of changing benefit indexation to non-switchers under reform I is identical to the impact under reform II as the basic DB scheme for non switchers is unchanged under the two reforms. In other words, the analysis of reforms I.2 and I.3 makes the same analysis in the hybrid reform redundant. We are of course interested in how replacement rates and expenditure are impacted by the hybrid reform. But the difference in results for reforms I and II will stem from new entrants only. Hence, in the hybrid option we simply model a reform scenario with wage indexation of benefits for non-switchers.

Given the complex nature of the analysis that follows we will re-define the reform options in turn as needed to facilitate the reader.

\section{V.A Transforming PSPF into provident fund (Reform I)}

Realizing the urgent need for reforming the PSPF, the Government is currently considering a drastic move to a public fully funded defined contribution scheme (provident fund) with an outsourced fund management. Based on our discussions with MPS, three options for this reform scenario were modeled:

Reform I.1 - everybody switches to the new system;

Reform I.2 - the new system is open only for new entrants with active members as of 2007 remaining in the old scheme; non switcher benefits are indexed to wages. 
Reform I.3 - the new system is open only for new entrants with active members as of 2007 remaining in the old scheme; non switcher benefits are indexed to prices.

Reform I.1, on the one hand, and Reforms I.2 and I.3, on the other hand, are two extreme cases with respect to how fast the fully funded defined contribution system is introduced to estimate the impact of the transition path on the system costs and benefits.

\section{V.A.1 Reform I.1}

Reform I.1 scenario was modeled as follows:

$>$ Reform starts in 2007.

Everybody switches to the new system.

$>$ Pension rights accrued under the old system are fully honored. The accrued rights are calculated based on individual's wage and years of service at the moment of reform and paid out when the person retires. Price indexation is applied to the calculated benefits between the year of reform and the year of retirement. The following rules are applied for accrued rights calculations: (1) with less than 20 years of service the person obtains a lump sum calculated using the short-service gratuity formula; (2) with 20 years and more the person obtains the CPG and a reduced pension calculated using the CPG and reduced pension formulae.

$>$ Contribution rate is 15\%: $5 \%$ paid by employee, $10 \%$ by employer. It is calibrated to achieve a target replacement rate of about $60 \%$ for the flow of new retirees.

$>$ Eligibility criteria related to retirement age remain the same. However, it is assumed that fewer people will retire early as the new scheme strengthens the link between benefits and contributions and, consequently, provides incentives to work longer. ${ }^{19}$

$>$ Benefits from the new system are paid out in the form of scheduled (programmed) withdrawals; no lump sum withdrawals are allowed; all types of gratuities offered by the old system are abolished. ${ }^{20}$

Administration/asset management fees start with a high $7 \%$ of assets to cover the start-up costs which then gradually go down to $1 \%$ by around 2020 . In a practically non-competitive environment, $1 \%$ is what major fund management companies currently operating in Uganda charge. In the long run, the fees are

\footnotetext{
${ }^{19}$ Other possible changes in behavior due to changes in incentives should be considered in further simulations.

${ }^{20}$ The non-practical suggestion of allowing for life annuities provided by insurance companies was discarded given the absence of fixed income assets required to immunize the fixed income liabilities, typical of the simplest forms annuity products. Allowing for annuity products with embedded options (say, with return of principal at death or other forms of guarantees) would obviously be even less practical. Nevertheless, should the Ugandan debt market develop with standardized issues of long term (ideally CPI indexed) bonds, a revision of the menu of retirement benefits would be justified.
} 
An Assessment Of Reform Options For The Public Service Pension Fund In Uganda

assumed to further decrease to a level of $0.7 \%$ due to a modest increase in asset management competition. ${ }^{21}$

$>$ No types of guarantees are provided.

$>$ Two variants are modeled for the assumed real interest rate earned on individual accounts (gross of administrative costs): 5\% (Reform I.1A) and 3\% (Reform I.1B). The two variants reflect the need to assess the probability that accumulated funds will be mismanaged. ${ }^{22}$

The impact of Reform I.1 on government expenditure ${ }^{23}$ is shown in Figure 18 and Figure 19. In the current non-contributory scheme all pension system payments are financed from the state budget. After the reform the government will have to cover the payment of the pension rights accrued under the old system and pay contributions to the new scheme as an employer (10\% of the wages).

\footnotetext{
${ }^{21}$ The high ratio of total costs over assets is explained by the maturity (or lack of) the new system. The fast growth of assets under management would rapidly lower the ratio due to the mainly fixed costs involved in managing a pool of assets. The long-run estimate of $0.7 \%$ ratio of total administrative costs over assets compares with high cost mandatory systems (like Chile). The marketing cost component included in most Latin American systems does not obviously apply to the new civil servant scheme in Uganda. One would therefore expect a lower cost structure. However, even in the good state of the world, the small (in \$ terms) pool of assets that the reformed civil servant scheme will generate is not likely to attract highly competitive asset managers. This justifies the long run assumption of total costs over assets of $0.7 \%$.

${ }^{22}$ Here, the choice of $3 \%$ real rate of return yields a zero differential with real wage growth. In essence, we consider the new scheme "mismanaged" if it yields a rate of return equal to the rate of return that can be obtained in the unreformed scheme. The definition of the bad state of the world is at all effects subjective and one can easily imagine a state of the world where the real returns on assets are negative. It is straightforward to have a qualitative idea of how replacement rates will behave for lower rates of return.

${ }^{23}$ The two variants - with higher and lower rate of return - have obviously no differential impact on government expenditure.
} 
Figure 18: Pure DC reform with immediate switching decreases considerably Government expenditure for civil servants, particularly in the medium and long term

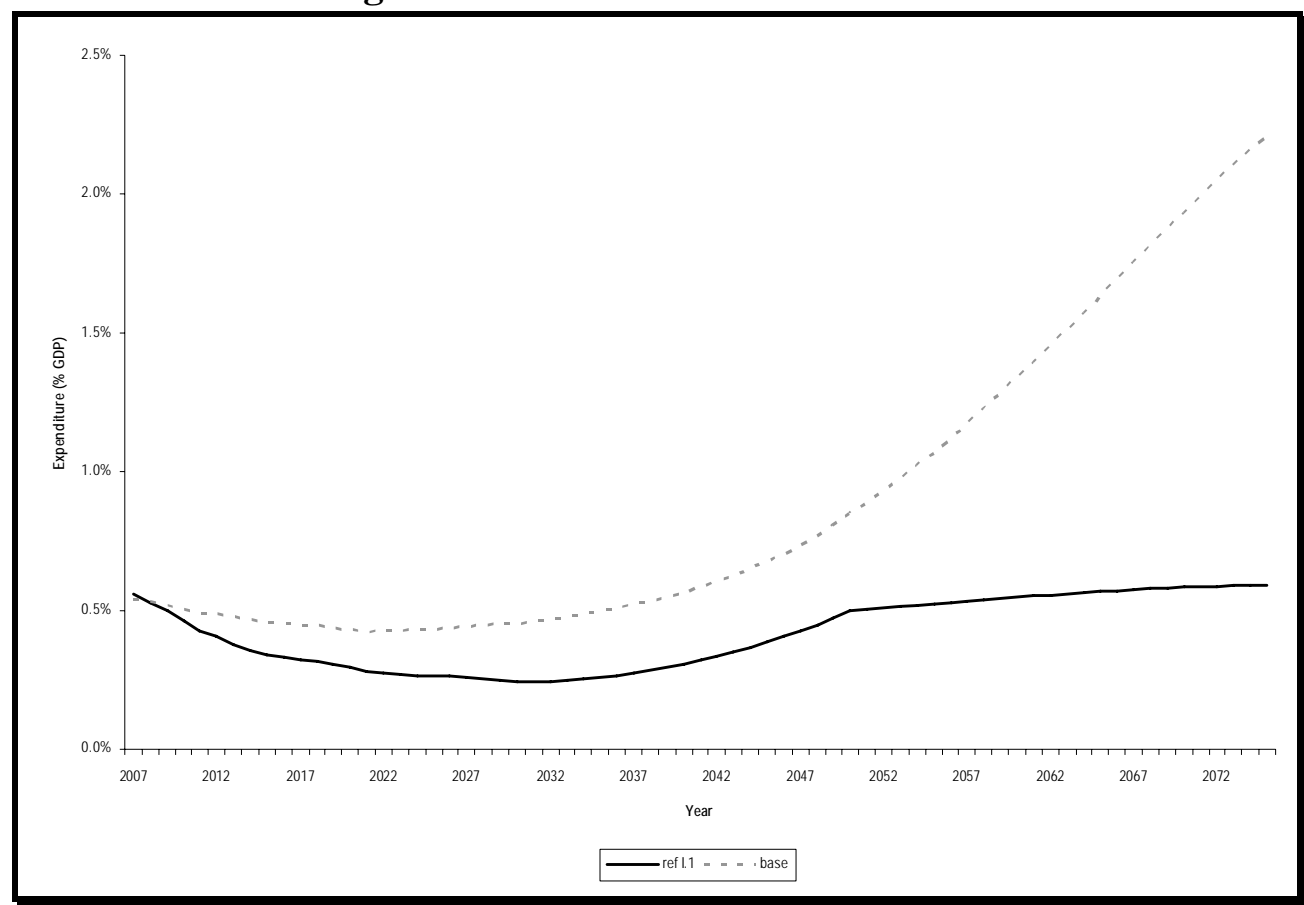

Source: WB calculations based on PROST

Figure 19: Pure DC reform with immediate switching decreases considerably government expenditure for teachers, except for the very few first years of the simulation period*

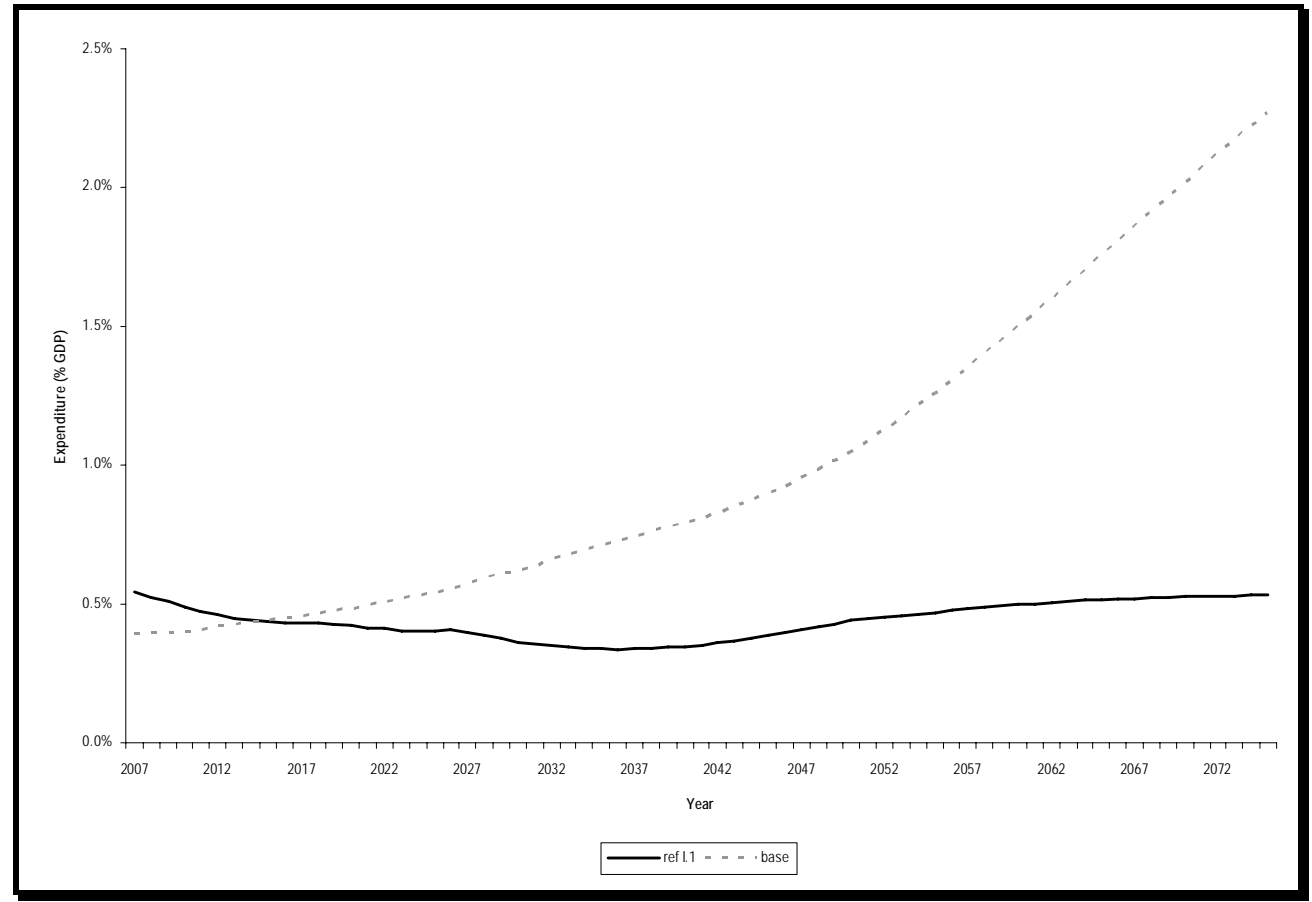

Notes: Comparisons of government expenditure for teachers - baseline with Reform I.1A (\% of GDP). Source: WB calculations based on PROST. 
In the short run, the cost to the government of the reformed system will slightly exceed the projected costs under a no-reform scenario. The decline in pension payments is not significant enough to offset the contribution payments to the provident fund which under the Reform I.1 variant will have to be paid for all active members. In the medium term, saving on the decreasing payments of the accrued rights more than compensates for the contribution payments that increase in line with the increasing wage bill. In the long run, after the accrued right have been practically paid out in full, government expenditure changes in line with the covered wage bill stabilizing at around 1.1\% of GDP. The projected time path of the two components of government expenditure after the reform is plotted in Figure 20 and Figure 21.

Figure 20: Payment of accrued rights and contributions for civil servants - Reform I.1A (\% of GDP)

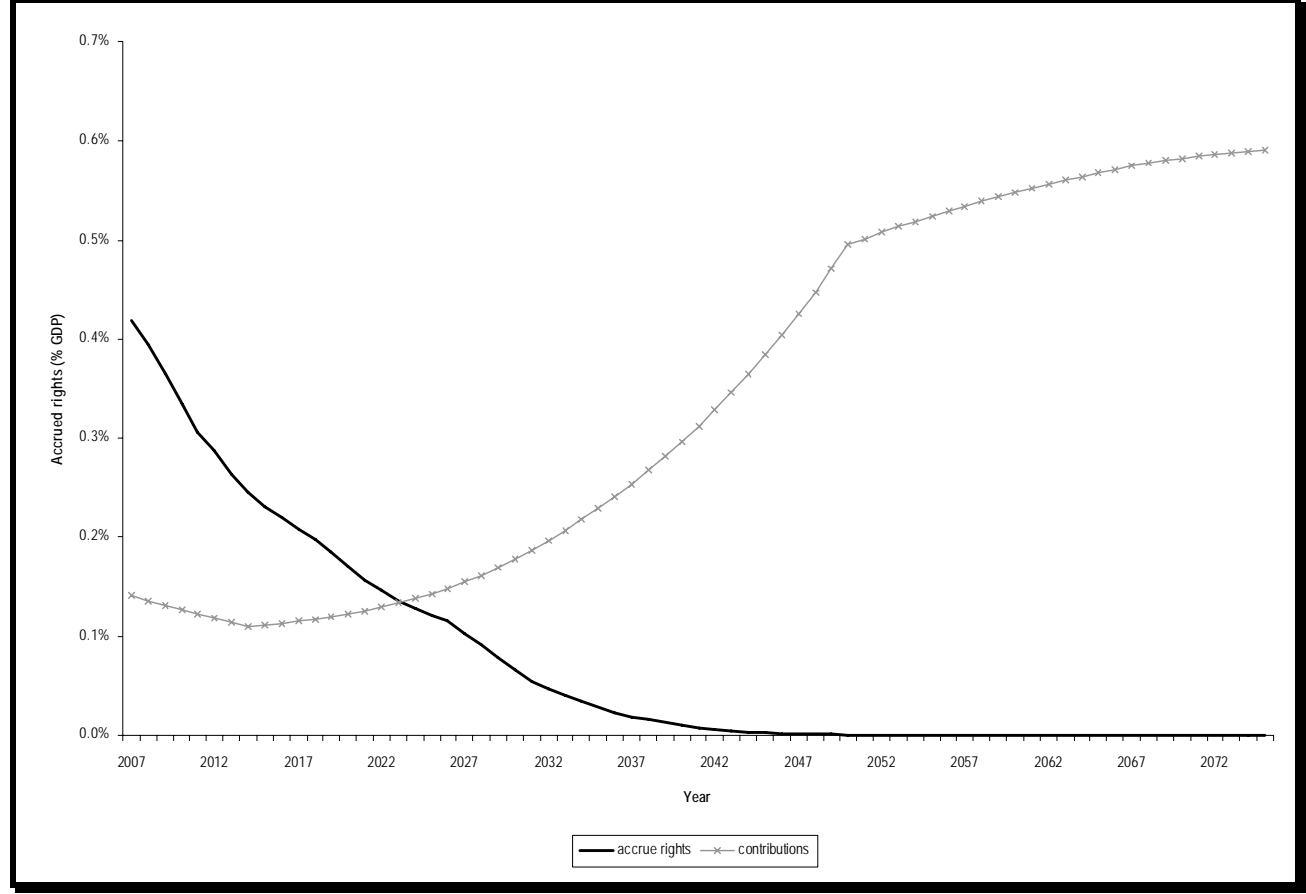

Source: WB calculations based on PROST 
Figure 21: Payment of accrued rights and contributions for teachers Reform I.1A (\% of GDP)

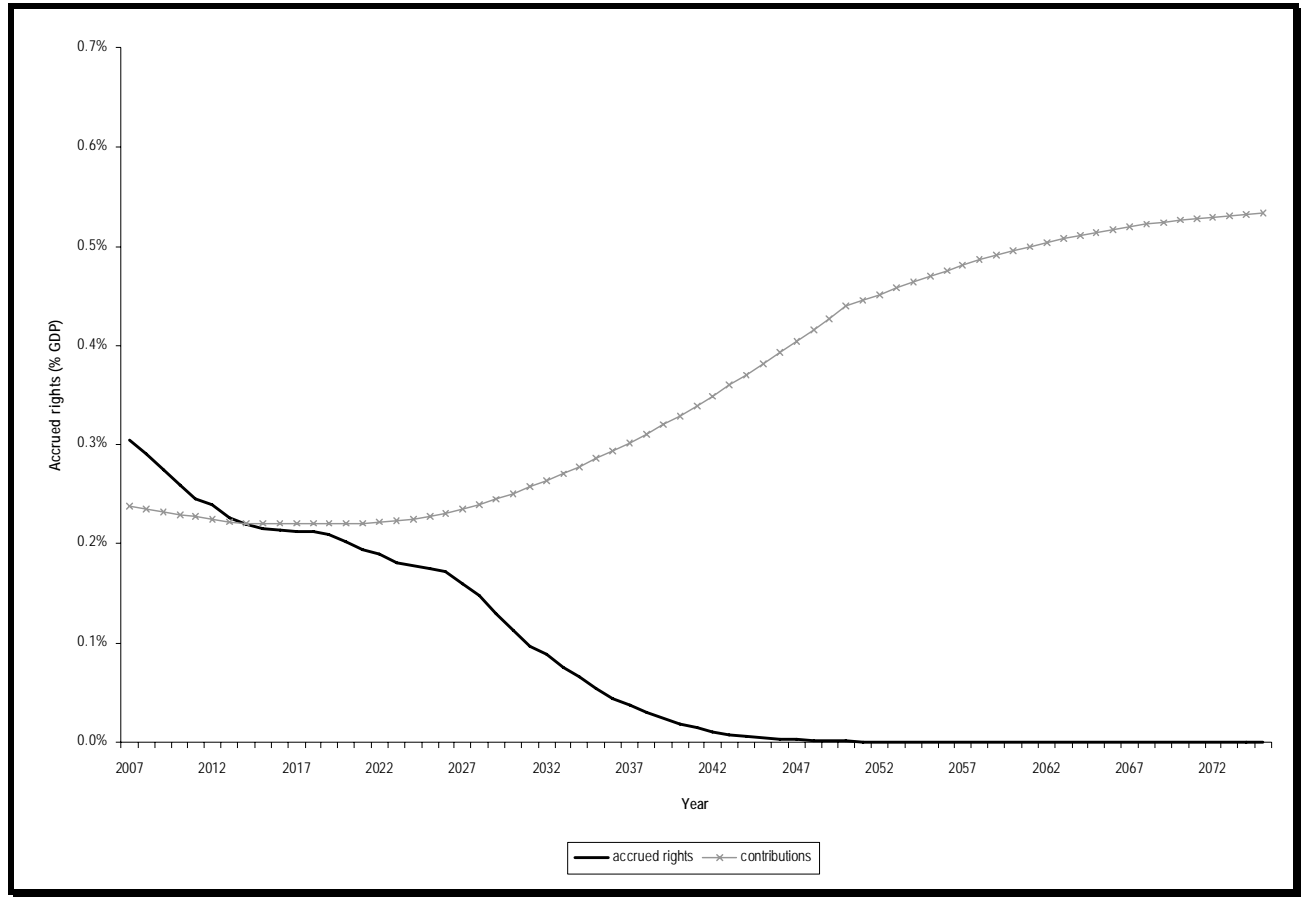

Source: WB calculations based on PROST

In the reformed system, benefits will be paid out of two sources: from the old defined benefit scheme in the form of accrued pension rights and from the new scheme as phased withdrawal based on the individual's accumulated balance. In the shorter run, while the value of benefits is dominated by the defined benefit component, replacement rates are higher. In the longer run, with the prevailing defined contribution component, the expected benefit becomes more modest compared to what is promised by the current system.

For example, under a quite optimistic assumption of 5\% rate of return, by the time the new system matures, the flow of retirees can expect replacement rates of about $60 \%$ for civil servants and 50\% for teachers. These are substantially lower compared to around $82 \%-85 \%$ that the same retirees would have obtained in the unreformed scheme. Pensions for the stock of retirees in the reformed scheme will decrease even more compared to the baseline due to the fact that price indexation increases the value of pensions by less than average wages. Replacement rates for the stock of old age pensioners projected for variant Reform I.1A (with 5\% real interest rate) are compared with the baseline (no-reform) scenario in Figure 22 and Figure 23. 
Figure 22: In a pure DC reform with immediate switching replacement rates* for stock of retirees for civil servants are lower than in the baseline scenario**

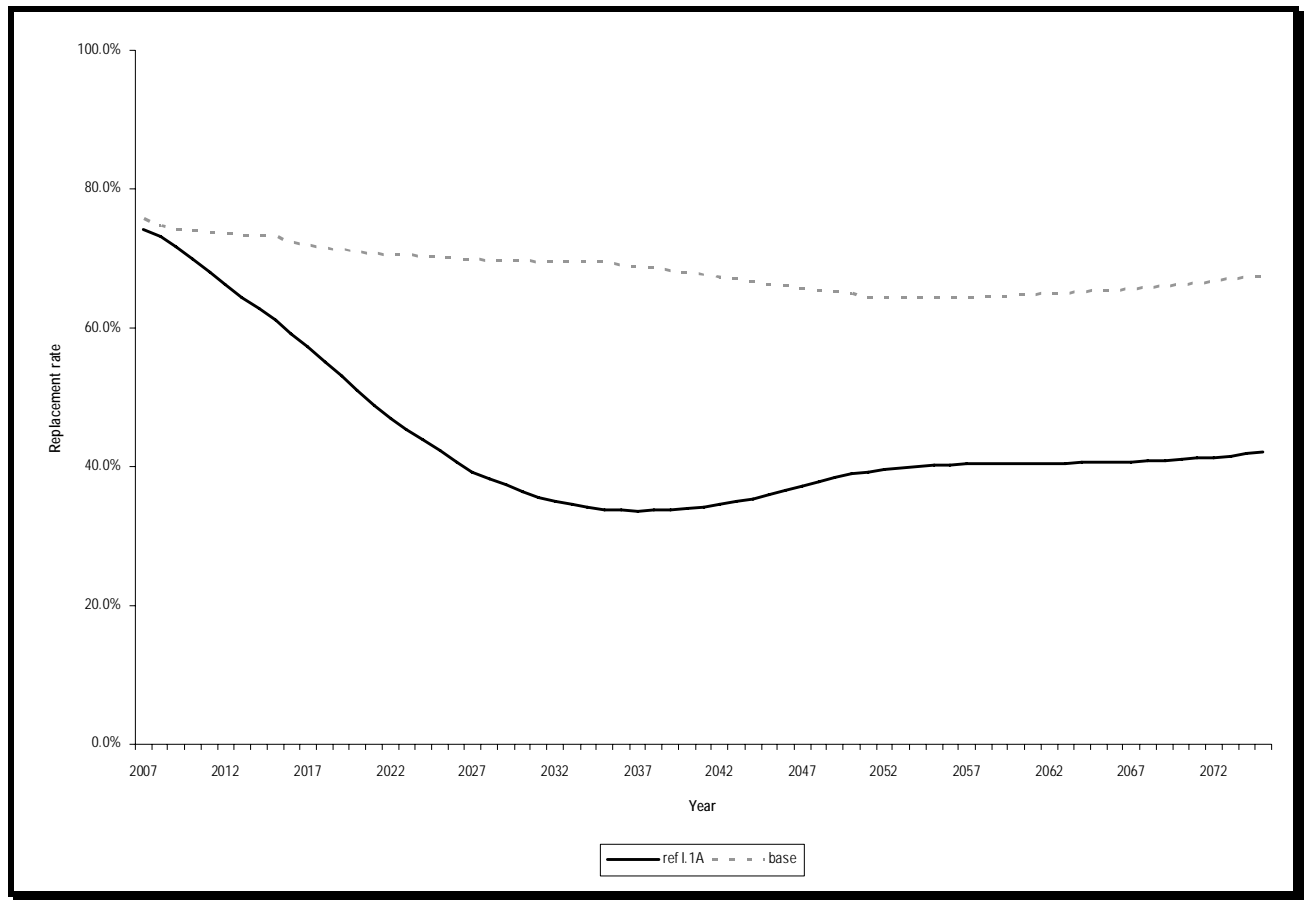

Notes: * Average pension as percentage of average group wage; ** Comparison of replacement rates* for stock of retirees for civil servants - baseline with Reform I.1A.

Source: WB calculations based on PROST. 
Figure 23: In a pure DC reform with immediate switching replacement rates* for stock of retirees for teachers will be lower than in the baseline scenario**

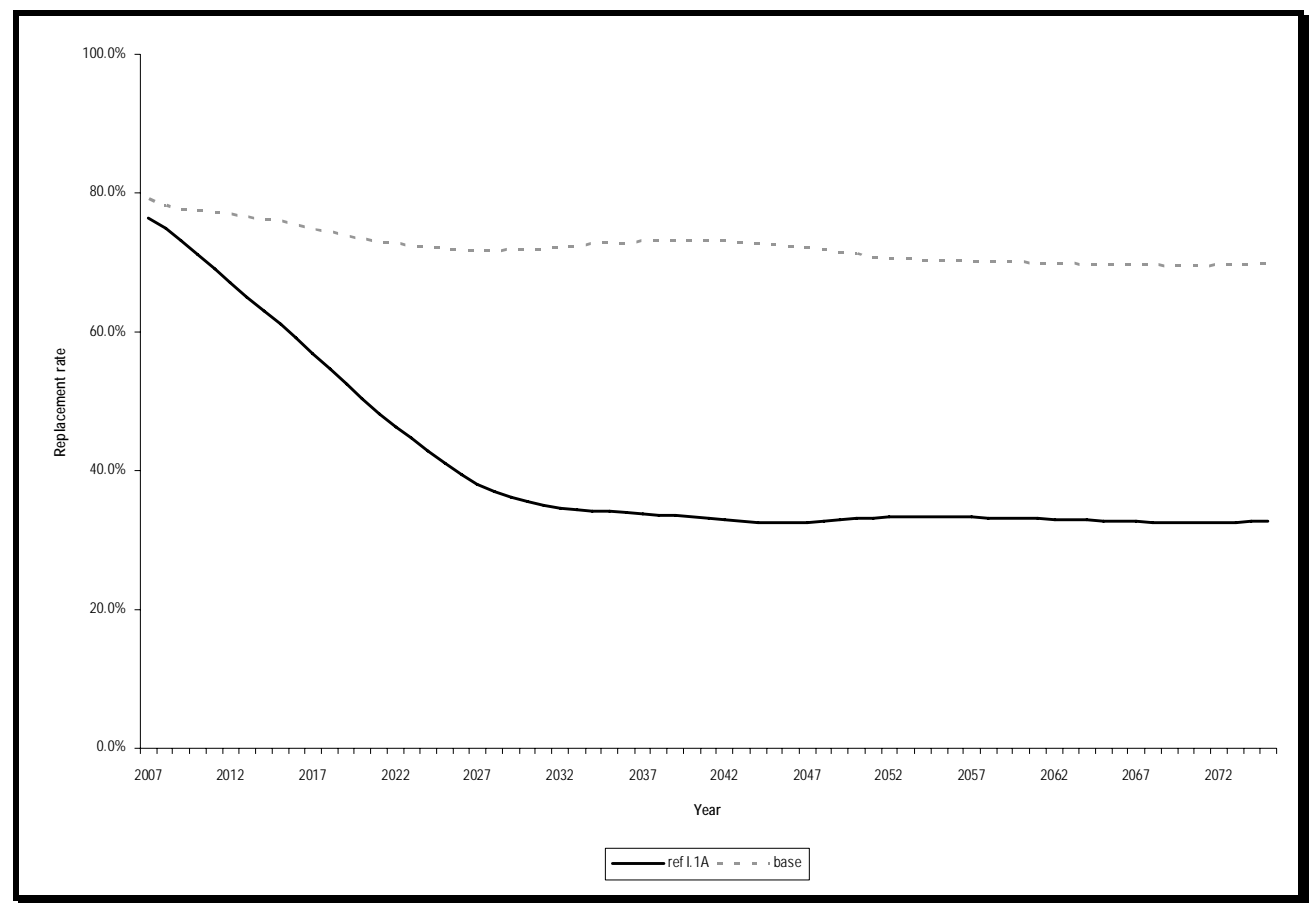

Notes: * Average pension as percentage of average group wage; ** Comparison of replacement rates for stock of retirees for teachers - baseline with Reform I.1A.

Source: WB calculations based on PROST.

Notice that we are comparing replacement rates produced by the reduced pension in the baseline with the replacement rates produced by the full pension in the reformed scheme. This would appear a rather drastic reduction in post-reform benefits relative to those projected with the generous benefit formula and indexation rules of the current scheme.

The interest rate earned on individual accounts is one of the key factors determining benefits in a defined contribution scheme. To illustrate how sensitive expected benefits are to financial market performance as well as the management of fund reserves, a less optimistic variant Reform I.1B is modeled. Under this scenario, assets accrue a 3\% real rate of return. Given the current international experiences in the management of public pension fund reserves, even 3\% real rate of return may turn out to be optimistic.

With real wage growth assumptions being the same, the difference between the real interest rate and real wage growth - one of the key determinants of the expected replacement rates - drops to zero in variant I.1B compared to about 2 percentage points in variant I.1A. The two percentage point difference in the assumed real rate of return has a substantial impact on benefits resulting in the replacement rates reduction of up to 12-15 percentage points in variant I.1.B compared to variant I.1.A. The impact of changes in the assumed rate of return on the defined contribution component of old age benefit is illustrated in Figure 24 and Figure 25. 
Figure 24: In a pure DC reform, rate of return on assets makes a big difference on the replacement rates* in the DC component for civil servants**

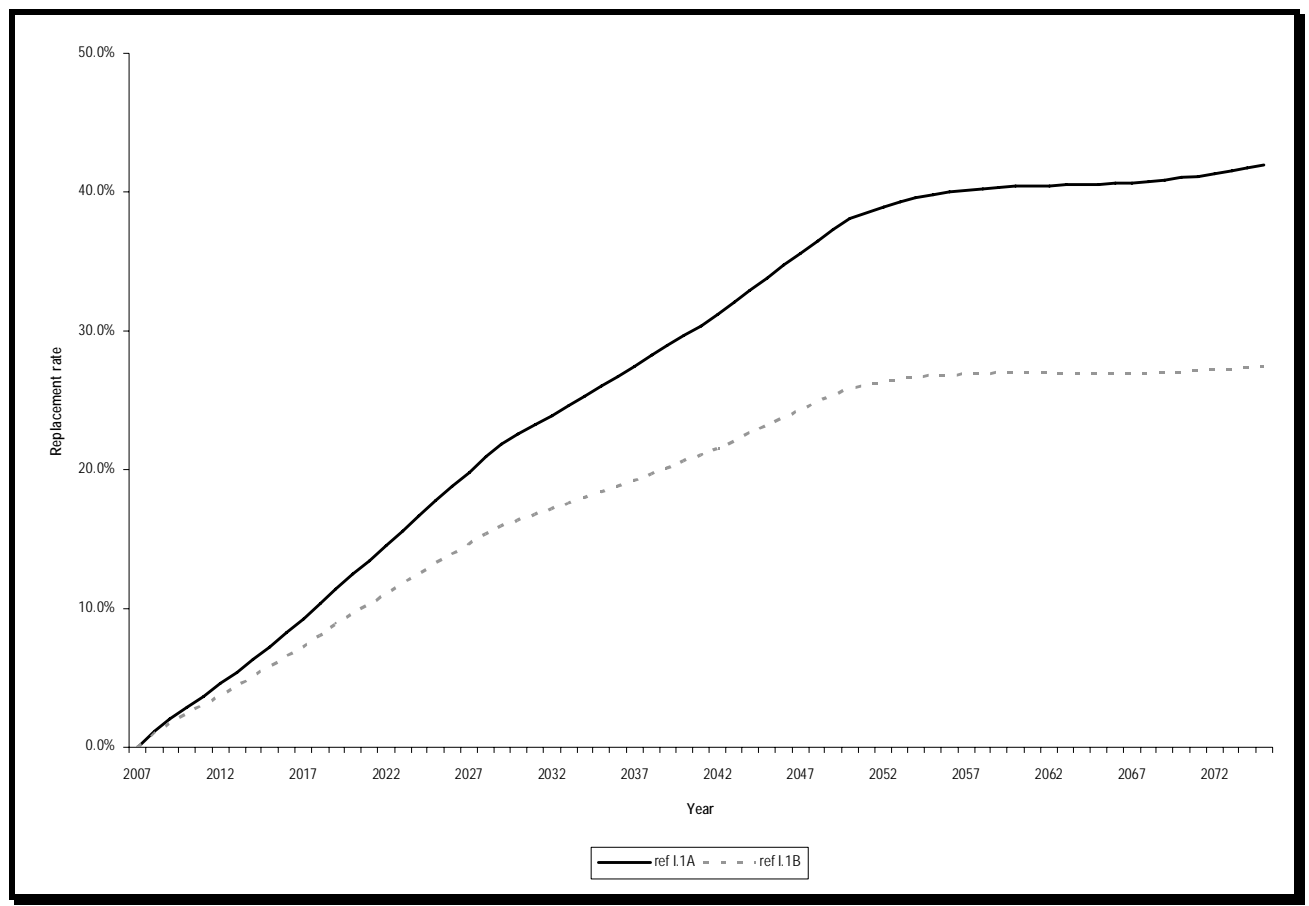

Notes: * Average pension as percentage of average group wage; Comparison of replacement rates in the DC component for civil servants - Reform I.1A with I.1B.

Source: WB calculations based on PROST. 
Figure 25: In a pure DC reform, rate of return on assets makes a big difference on the replacement rates* in the DC component for teachers**

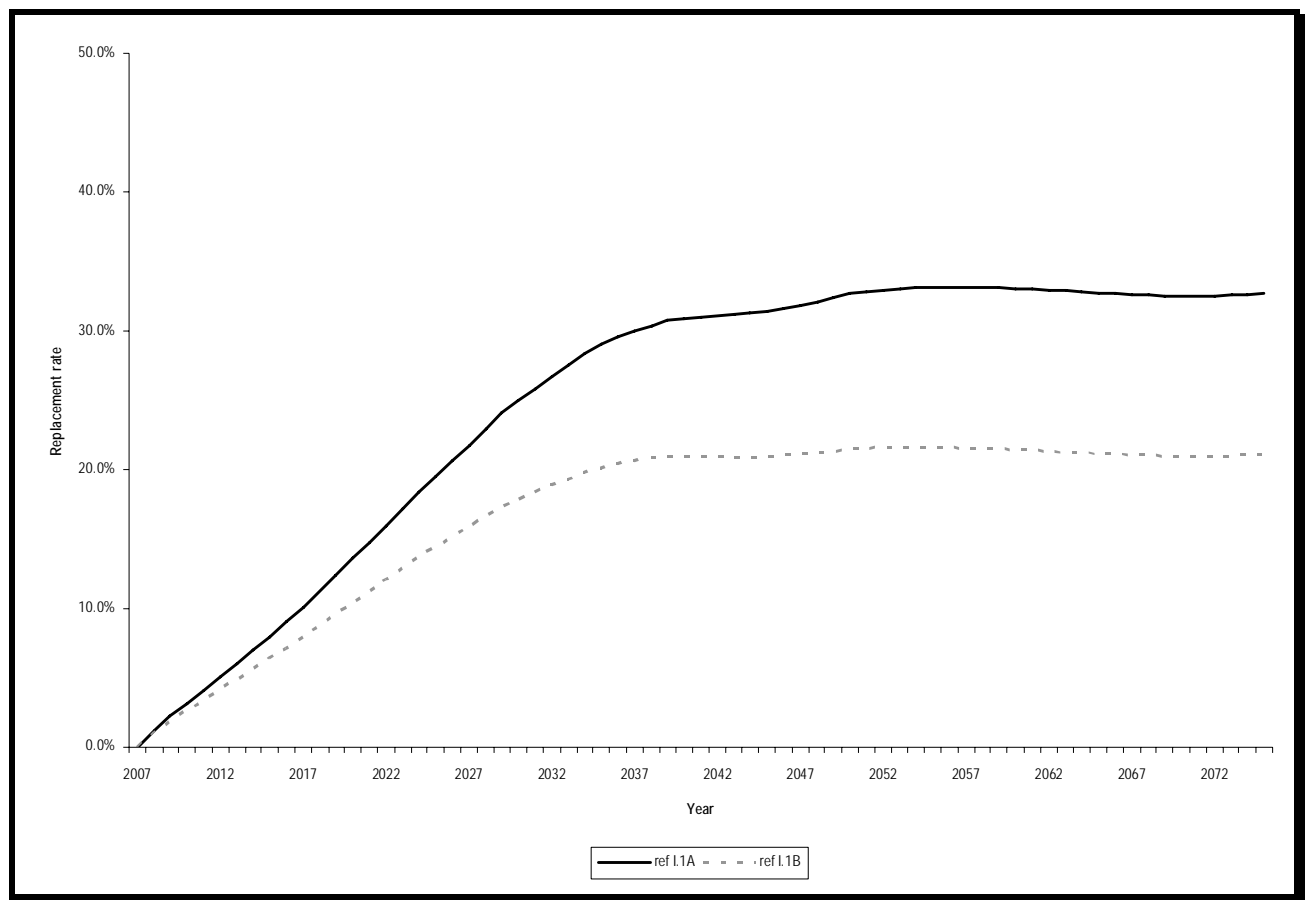

Notes: * Average pension as percentage of average group wage; ** Comparison of replacement rates* in the DC component for teachers - Reform I.1A with I.1B.

Source: WB calculations based on PROST.

\section{V.A.2 Reforms 1.2 and I.3}

Same shift to a pure provident fund but with a different transition path is modeled in the Reform I.2 and Reform I.3 scenarios:

$>$ Only new entrants join the new system.

$>$ Only one variant is modeled with respect to the assumed real interest rate earned on individual accounts (5\%). The qualitative impact previously discussed if assets are mismanagement obviously applies in this reform scenario as well.

All other design features assumed to be the same as in Reform I.1.

The only difference between the two scenarios is the indexation rules in the remaining old system:

Reform I.2: same indexation rules (wage indexation) as in the current system;

Reform I.3: price indexation applied to full pensions with no indexation applied to the commuted part

The impact of the transition path can be seen by comparing Reform I.2 and I.1A. In the first years, government obligations in the former are lower as with gradual transition contributions will have to be paid only for few new employees who join the system after the reform. However, later in the future the option with gradual transition becomes much more costly than the radical shift given that the contributions required to be paid to the 
new scheme pick up fast while pension payments decrease more slowly than in Reform I.1 (in fact, pension payments continue growing over the first three decades). The impact on government expenditure is presented in Figure 26 and Figure 27.

Figure 26: Pure DC reforms make Government expenditure for civil servants much lower than in baseline scenario*

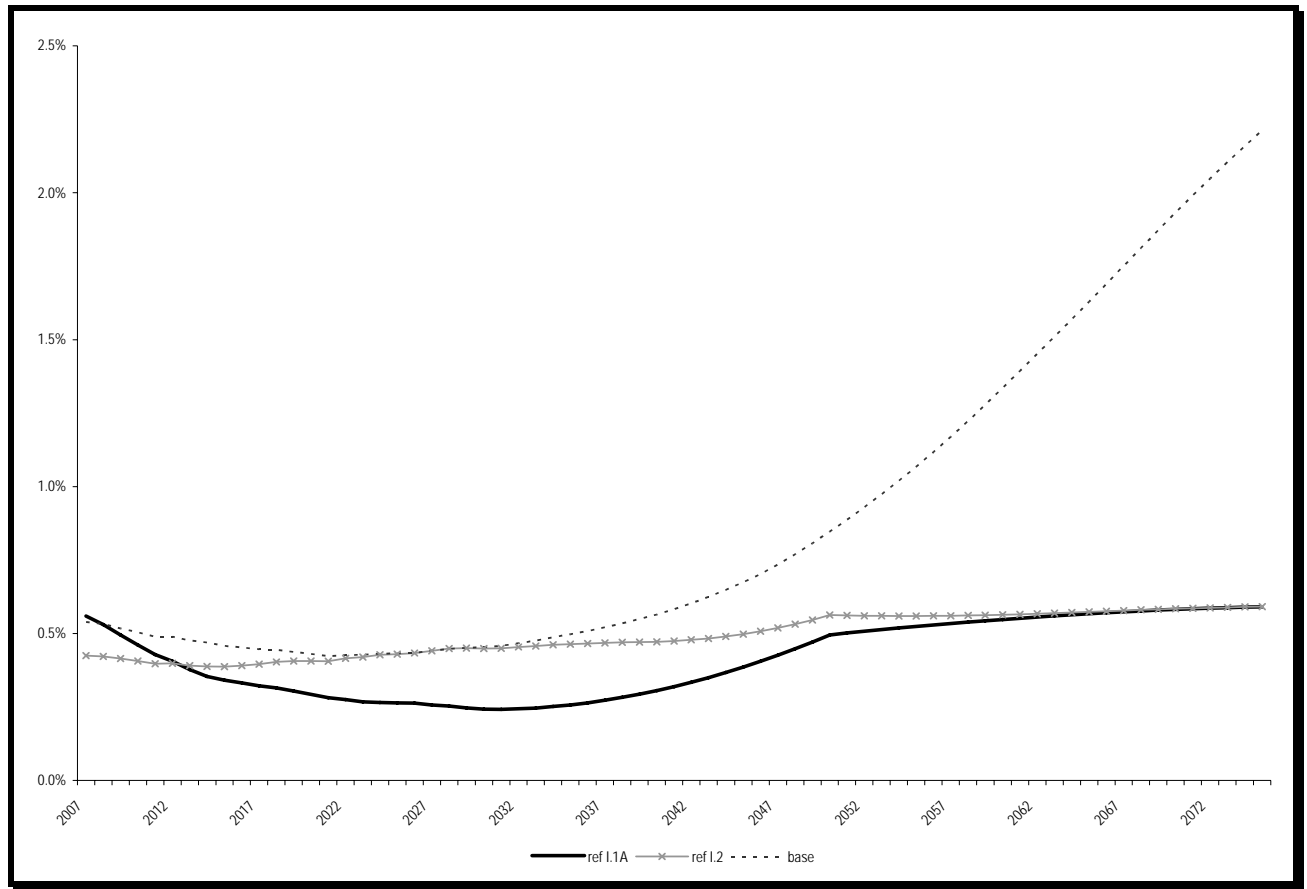

Notes: * Comparison of Government expenditure for civil servants - Reform I.1A, I.2 with baseline (\% of GDP).

Source: WB calculations based on PROST. 
Figure 27: Pure DC reforms make Government expenditure for teachers much lower than in the baseline scenario*

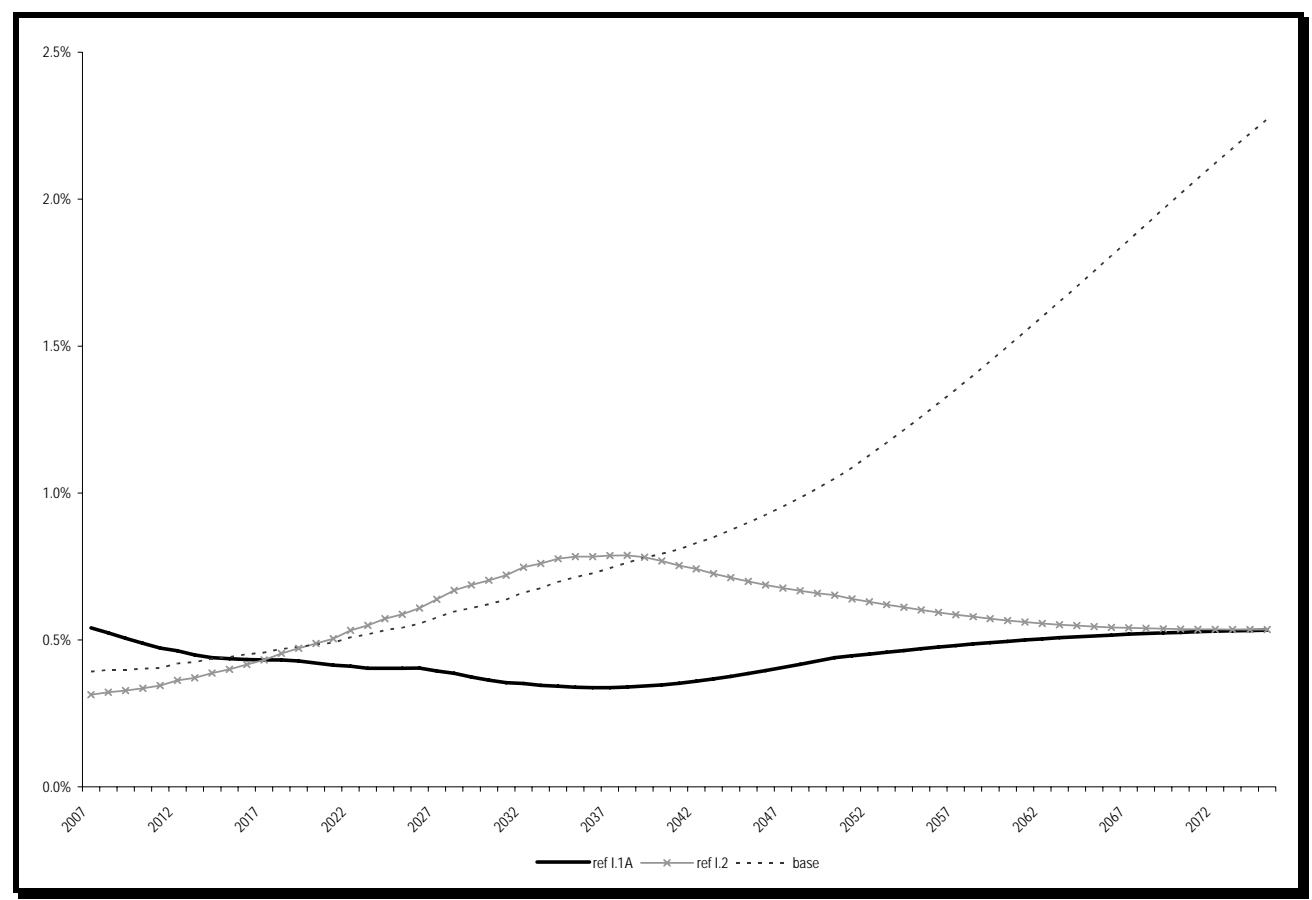

Notes: * Comparison of Government expenditure for teachers - Reform I.1A, I.2 with baseline (\% of GDP).

Source: WB calculations based on PROST.

From the expected benefit point of view, Reform I.2 may sound more appealing to current system members, but only assuming the government manages to cope with the fiscal pressure which may exceed even the baseline projections during some periods in the medium term.

Replacement rates for those staying in the old scheme are compared with replacement rates projected for funded scheme members in Figure 28 and Figure 29. Here, replacement rates are calculated as a percentage of the group average wage for the total covered population in both the old and the new scheme. One may notice that members of the defined benefit scheme obtain somewhat higher replacement rates compared to the baseline scenario. This can be explained by the assumed changes in behavior resulting in changes in the age distribution of new retirees: once the system is closed to new entrants, the average retirement age and hence the average wage and length of service of new retirees increase producing higher replacement rates in terms of the general group average wage. 
Figure 28: In a pure DC reform for only new entrants, replacement rates*, for non switchers are higher than for switchers**

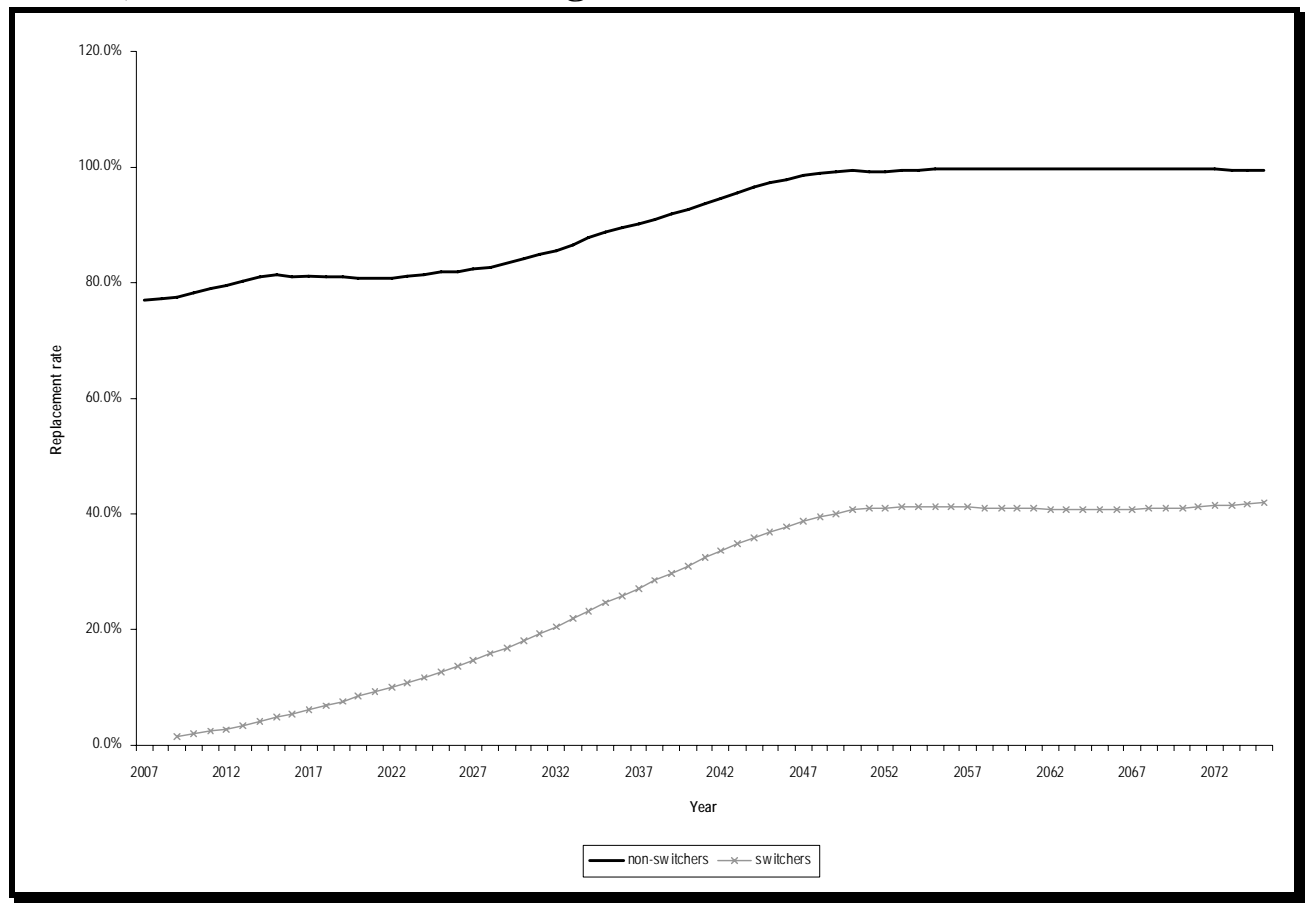

Notes: * Average pension as percentage of the group average wage; ** Comparison of replacement rates in Reform I.2 for civil servants - switchers with non-switchers.

Source: WB calculations based on PROST. 
Figure 29: In a pure DC reform for only new entrants' replacement rates* for non-switchers are higher than for switchers**

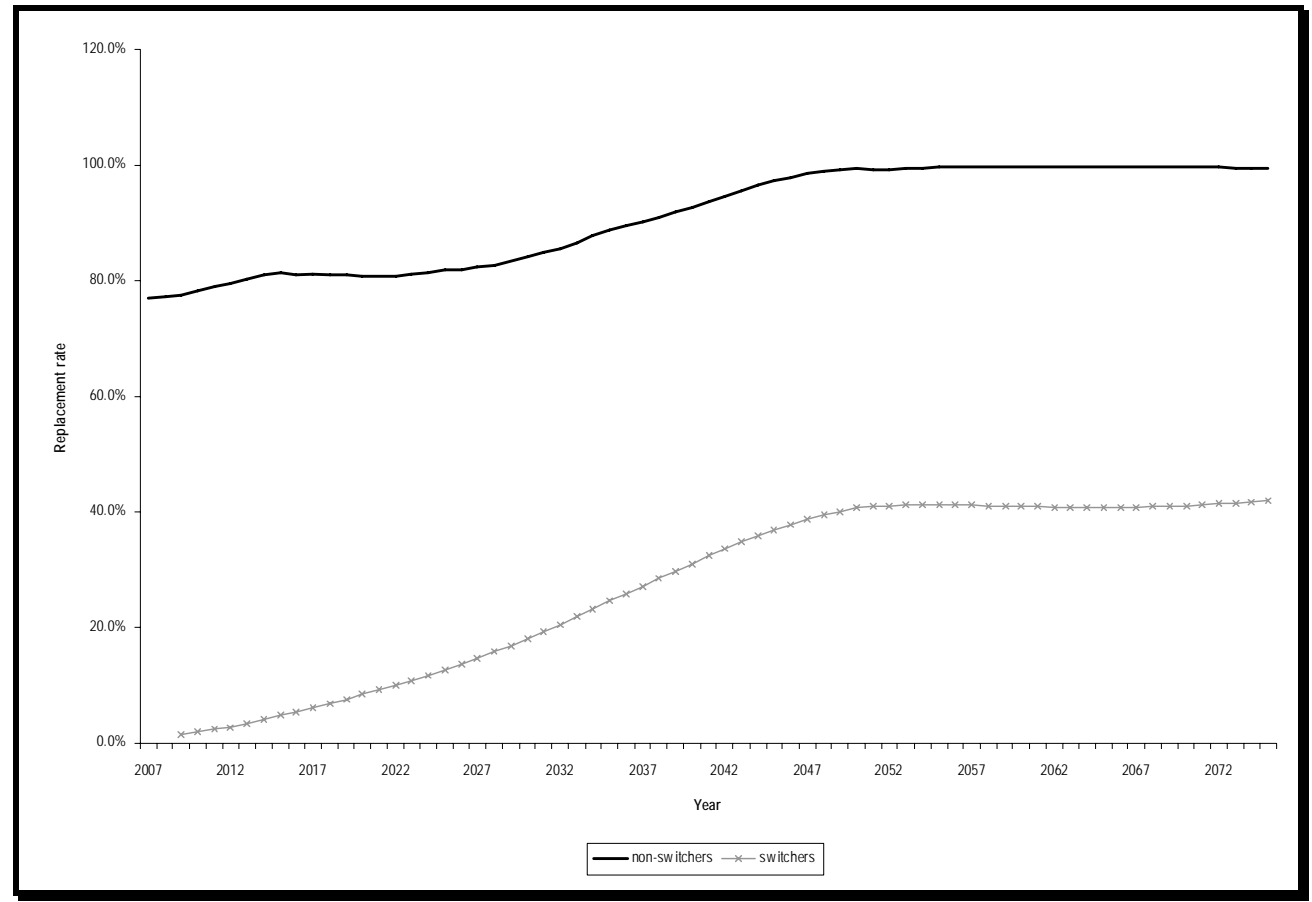

Notes: * Average pension as percentage of average group wage; ** Comparison of replacement rates in Reform I.2 for teachers - switchers with non-switchers.

Source: WB calculations based on PROST.

The cost of wage indexation in the remaining old scheme was estimated by comparing Reform I.2 and Reform I.3. With the real wage growth assumed to be positive throughout the simulation period, wage indexation may increase pension expenditure by up to $0.1 \%$ of GDP, as illustrated in Figure 30 and Figure 31. On the other hand, price indexation may drastically reduce average replacement rates for the stock of retirees remaining in the defined benefit scheme (Figure 32 and Figure 33). 
Figure 30: Price indexation lowers Government expenditure for civil servants more than wage indexation does**

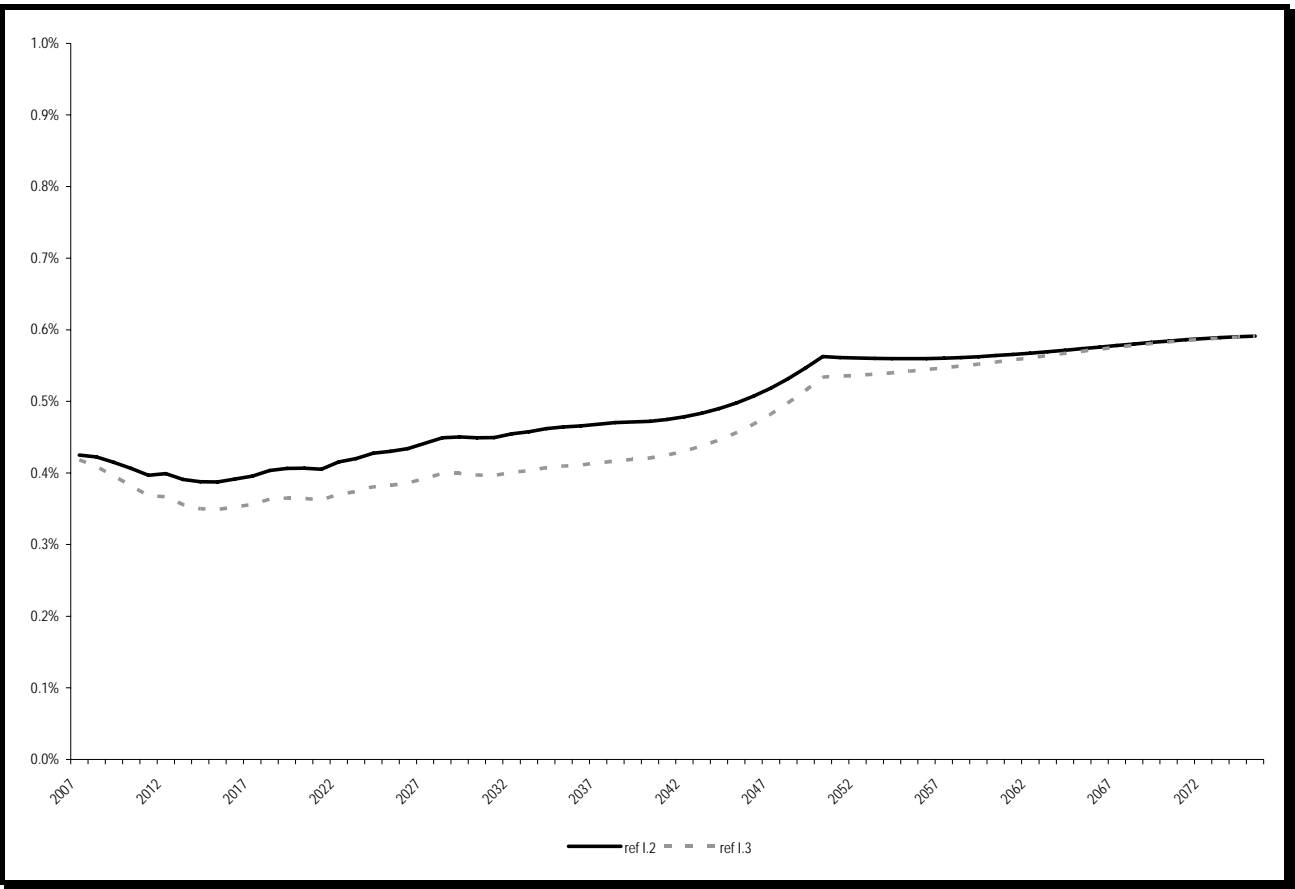

Notes: ** Comparison of Government expenditure for civil servants - Reform I.2 with I.3 (\% of GDP).

Source: WB calculations based on PROST.

Figure 31: Price indexation lowers Government expenditure for teachers more than wage indexation does

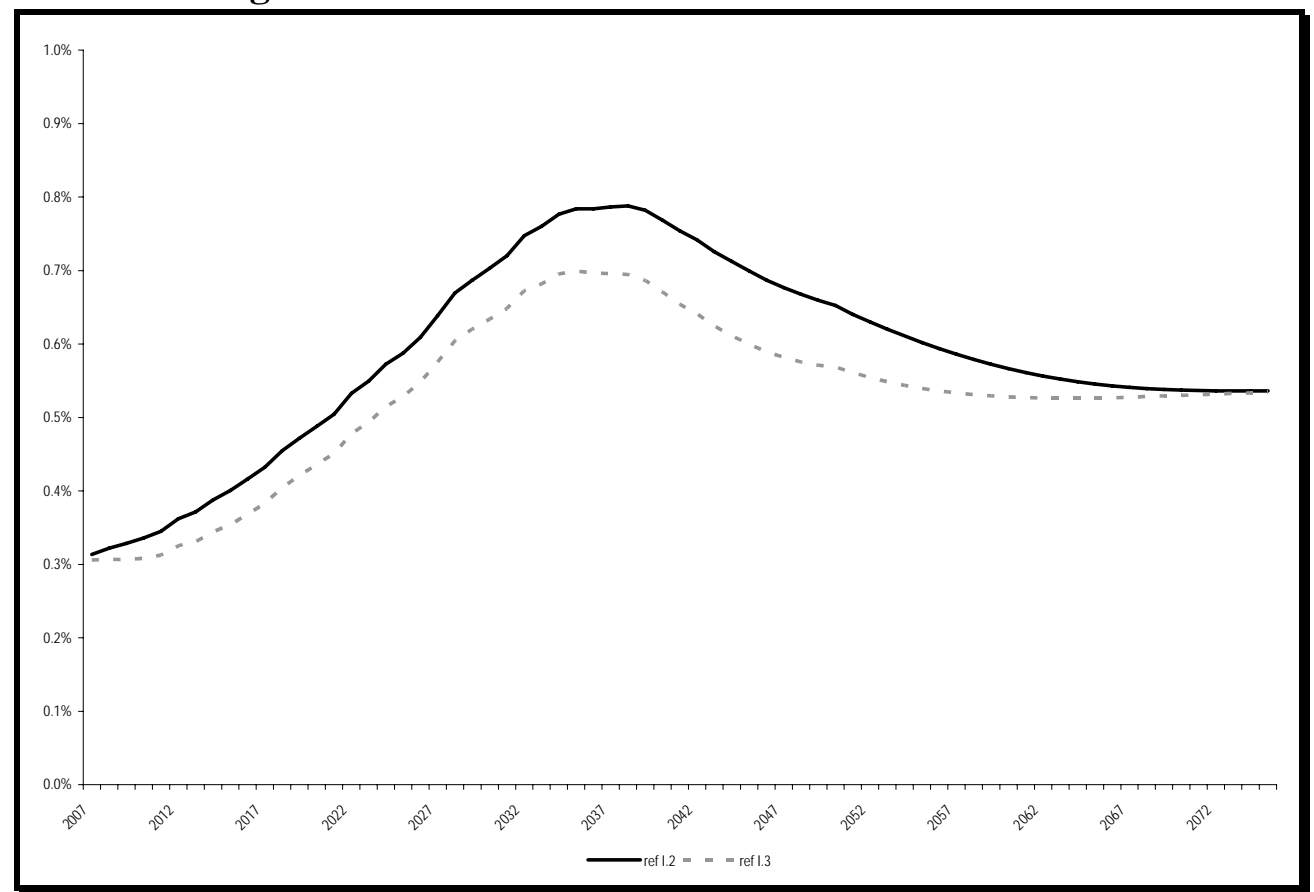

Notes: ** Comparison of Government expenditure for teachers - Reform I.2 with I.3 (\% of GDP).

Source: WB calculations based on PROST. 
Figure 32: Price indexation is another way to gradually decreasing replacement rates* for civil servants and reduce the fiscal impact of the current scheme**

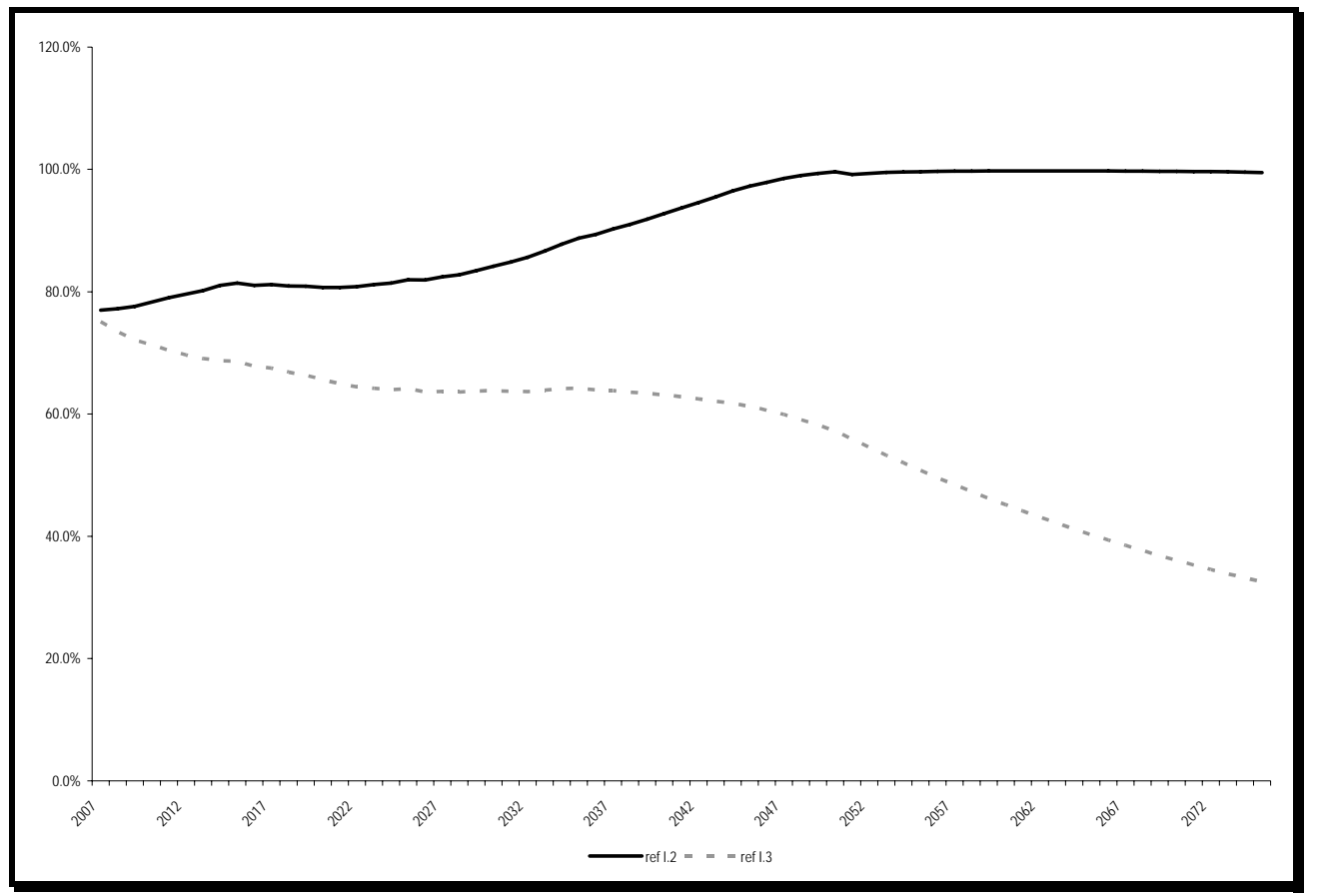

Notes: * Average pension as percentage of average group wage; ** Comparison of replacement rates for civil servants - Reform I.2 with I.3.

Source: WB calculations based on PROST. 
Figure 33: Price indexation is another way to gradually decreasing replacement rates* for teachers and reduce the fiscal impact of the current scheme**

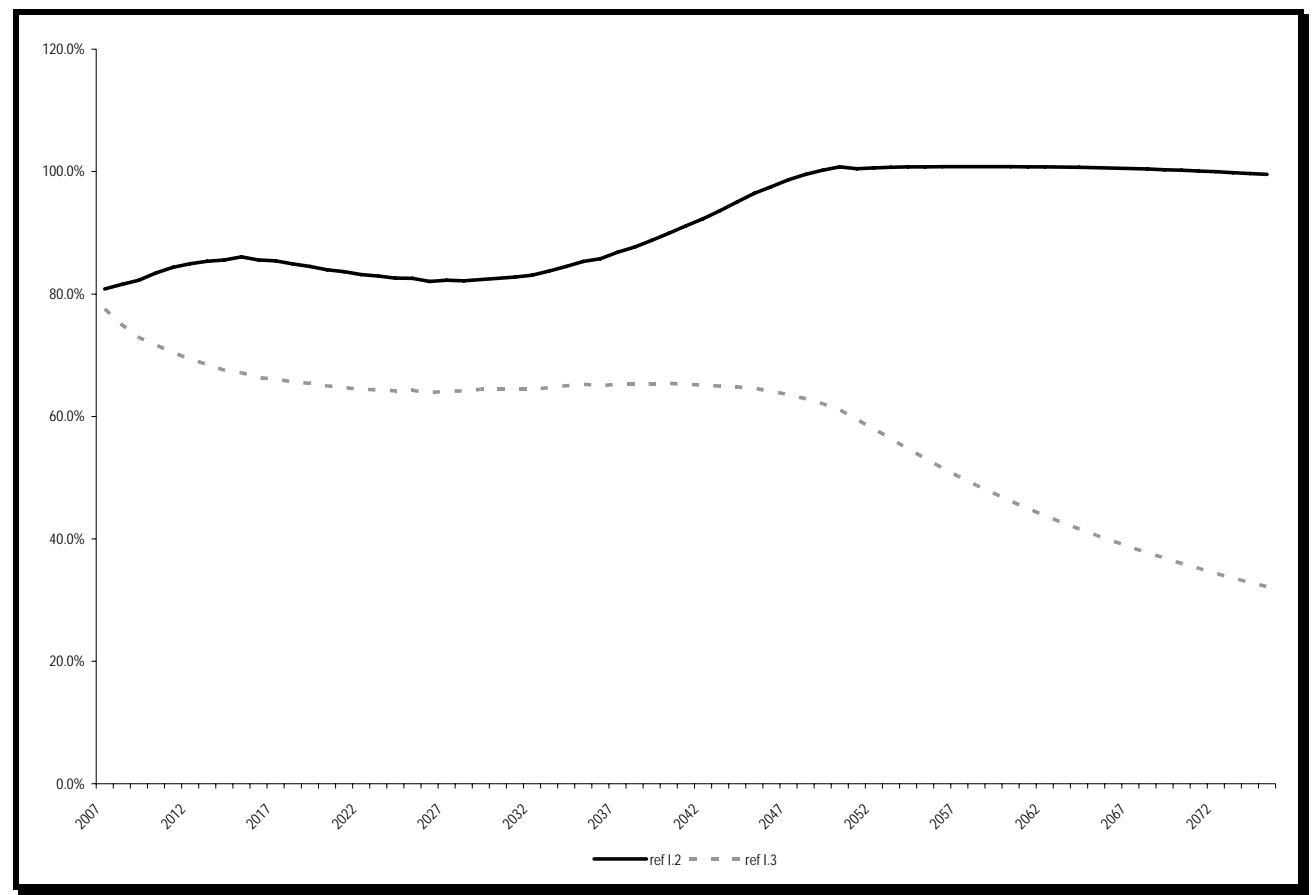

Notes: * Average pension as percentage of average group wage; ** Comparison of replacement rates for teachers - Reform I.2 with I.3.

Source: WB calculations based on PROST.

\section{V.B Transforming PSPF into a mixed scheme (Reform II)}

The reform from the current monopillar PAYG defined benefit scheme to a two-pillar scheme is modeled as one of the possible alternatives to a drastic shift to a pure fully funded defined contribution system. The first pillar in this provisional reform scenario is suggested to be a funded defined benefit component, the second - a fully funded defined contribution scheme similar to the previous reform scenario, though smaller in size.

Similar to the pure defined contribution reform scenario, simulations are done for two extreme cases of the transition path: 1) everybody moves to the new scheme in the year of reform (Reform II.1); and 2) only new entrants go to the new scheme with current (as of the year of the reform) active members staying in the old system (Reform II.2).

\section{V.B.1 Reform II.1}

The main design features of this hybrid reform scenario are as follows:

$>$ Reform starts in 2007.

$>$ Everybody switches to the new system.

$>$ Pension rights accrued under the old system are treated the same way as in Reform I.1.

The contribution rate is 15\%: $5 \%$ paid by employee, $10 \%$ by employer.

Contributions are split between two pillars: up to a specified ceiling they go to the 
first pillar ${ }^{24}$ and above the ceiling - to the second pillar, ${ }^{25}$ so the contribution ceiling in the first pillar equals the contribution floor in the second pillar.

$>$ The ceiling/floor is set at two times the average wage in the year of the reform with further indexation to prices until it reaches the minimum wage, ${ }^{26}$ remaining equal to the minimum wage thereafter.

First pillar:

- Vesting period 10 years;

- $2 \%$ annual accrual rate;

- Maximum replacement rate $=80 \%$ of the reference wage defined in next bullet;

- Reference wage for benefit calculation = individual's last wage subject to the ceiling;

- Pensions are indexed to prices;

- Pension commutation is not allowed;

- Pension fund reserves accumulated in the first pillar are invested at the same interest rate as in the funded component.

Second pillar:

- Except for the abovementioned contribution floor, the second pillar design is the same as in the pure DC scenario.

- Like for Reform I.1, two variants are modeled for the assumed real interest rate earned on individual accounts (gross): 5\% (variant II.1A) and 3\% (variant II.1B).

Retirement pattern is assumed to change the same way and for the same reasons as in the pure DC scenario.

The defined benefit pillar is more modest than the current scheme due to a less generous benefit formula as well as to the ceiling imposed on pensionable income. Over time, the ceiling indexation downsizes the defined benefit component even further and eventually transforms the initially earnings related benefit into a flat pension for everybody meeting the eligibility criteria. ${ }^{27}$ Towards the end of the simulation period an average new retiree

\footnotetext{
${ }^{24}$ Essentially a downsized DB contributory PSPF.

25 The two pillars could be managed by the same institution or be completely separate where civil servants are allowed to contribute to a national provident fund or a private sector DC plan. The important thing is that the first pillar is a DB scheme while the second pillar is a DC scheme.

${ }^{26}$ In the simulations, by minimum wage we understand the lowest wage received by the covered population. The ceiling/floor is projected to reach the minimum wage by 2059 in the civil servants subscheme and by 2053 in the teachers sub-scheme.

${ }^{27}$ Indexing the contribution ceiling to prices has the advantage of achieving a "pure defined contribution reform” in a very gradual fashion with the added bonus of introducing an earning-related flat benefit (flat benefit per year of service) for all members. With price indexation, the ceiling is expected to reach the minimum wage after 45 years from the reform.
} 
is projected to obtain from the first pillar around $13-15 \%$ of the unconstrained ${ }^{28}$ average wage regardless of his/her income. Notice that, by international standards, this is a low replacement rate for a first pillar DB pension. However, due to the design of the ceiling indexation the first pillar is being gradually phased out in a minimum pension affine to a sort of a flat benefit. $13-15 \%$ of the average wage may be a reasonable level for a guaranteed minimum pension.

If the new defined benefit component is not in deficit, the government expenditure in Reform II.1 will be exactly the same as in Reform I.1. This is due to the fact that the switching pattern is the same (everybody switches to the new scheme), accrued rights are calculated and paid out in the same way, and the contributions paid to the new scheme are the same (same number of active members with the same wages). In both variants II.1A (5\% real interest rate) and II.1B (3\% real interest rate) the defined benefit pillar is projected to be in surplus accumulating reserves throughout the simulation period comparable with the second pillar reserves. Even in the case of zero nominal rate of return on first pillar reserves investments, the current balance will remain positive almost until 2075. The main factor contributing to that is the accelerated coverage expansion assumed between 2015 and 2050 .

In summary, from the costs-to-the-government point of view Reform II may be equivalent to the pure DC reform scenario. However, for beneficiaries the outcomes may be different, especially for lower income groups. Table 12 compares average replacement rates projected for the last few years of the simulation period (when the new scheme matures) for the stock of old age pensioners under Reform I.1 and Reform II.1 with 5\% and 3\% assumed as the real interest rate earned on individual accounts.

Table 12: Projected average replacement rates* for the stock of retirees (average over 2070 - 2075)

\begin{tabular}{|c|c|c|c|c|}
\hline & \multicolumn{2}{|c|}{$\mathbf{5 \%}$ interest rate } & \multicolumn{2}{c|}{$3 \%$ interest rate } \\
\cline { 2 - 5 } & government & teachers & government & teachers \\
\hline Reform I.1 & $42 \%$ & $33 \%$ & $27 \%$ & $21 \%$ \\
\hline Reform II.1** & $42 \%$ & $40 \%$ & $34 \%$ & $35 \%$ \\
\hline
\end{tabular}

Notes: * Average pension as percentage of average group wage, **Combined replacement rate from two pillars Source: WB calculations based on PROST

Under a more favorable investment return assumption (5\% real), teachers - earning on average less than civil servants - would be better off in a two-pillar scheme rather than in a pure defined contribution, whereas for higher income groups the outcomes are likely to be similar. However, if invested funds can only earn 3\% real, all groups would fair better under the two-pillar scheme, with lower income groups gaining more than higher income groups. Thus, the first pillar will perform redistributive function providing some sort of a minimum pension guarantee which is not stipulated in Reform I. In addition, it provides some insurance against investment risk for system participants.

\section{V.B.2 Reform II.2}

Similar to Reform I, a gradual transition path is modeled for the two-pillar reform scenario assuming that the new two-pillar scheme is introduced only for employees

${ }^{28}$ Unconstrained wage=wage before the ceiling/floor is applied 
joining the system after the reform. Only one variant is modeled with respect to benefit indexation and rate of return: wage indexation in the remaining old scheme and 5\% real interest rate on investments.

Compared to the immediate switching for all, allowing only new entrants to join the new scheme will have the same impact on expenditure as discussed in the pure defined contribution reform scenario. The impact on government expenditure is presented in Figure 34 and Figure 35.

\section{Figure 34: Hybrid reforms lowers Government expenditure for civil} servants but expenditures patterns are identical to the pure DC reform*

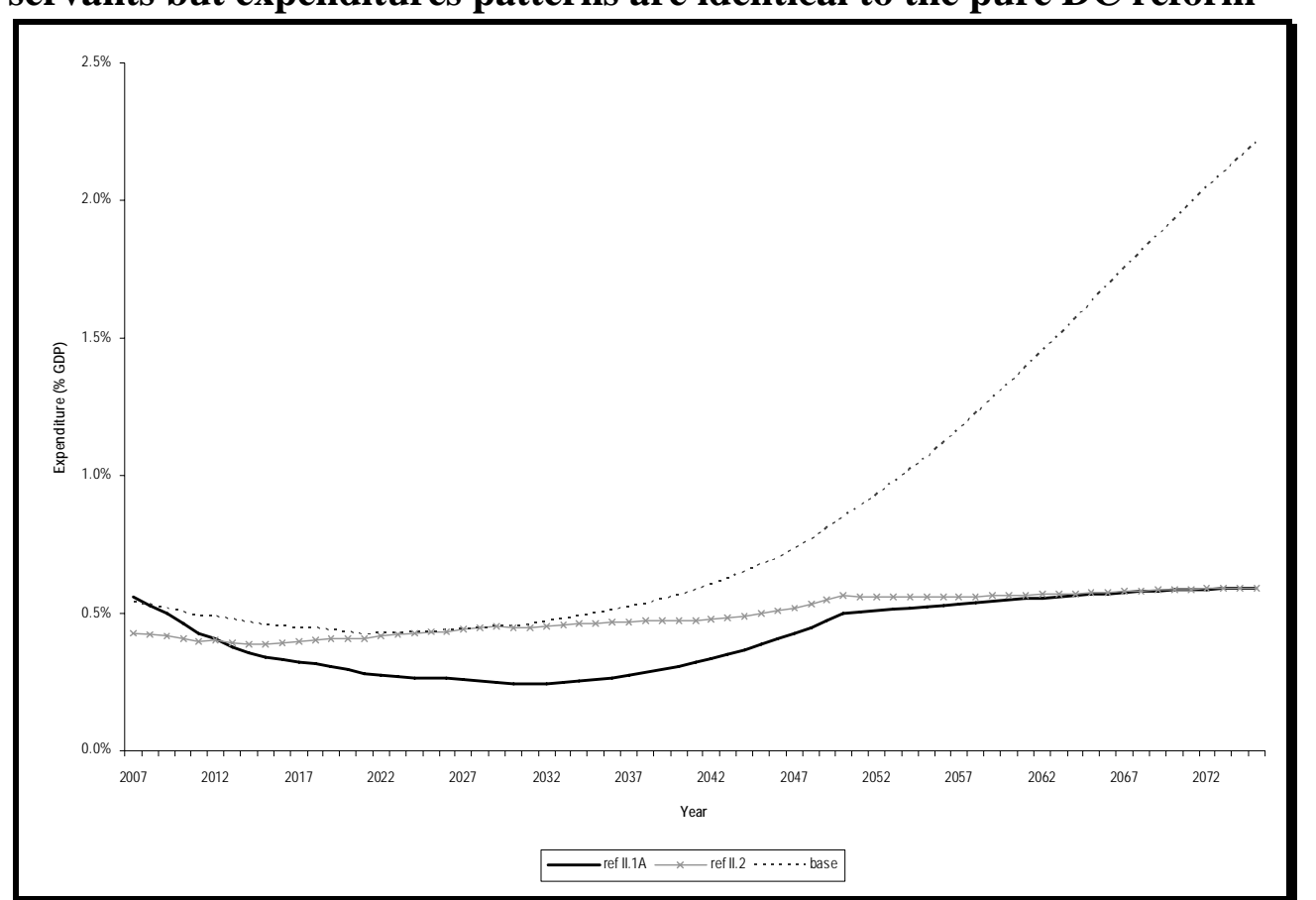

Source: * Comparison of Government expenditure for civil servants - Reform II.1A, II.2 with baseline (as \% of GDP).

Source: WB calculations based on PROST. 
Figure 35: Hybrid reforms lowers Government expenditure for teachers but expenditures patterns are identical to the pure DC reform*

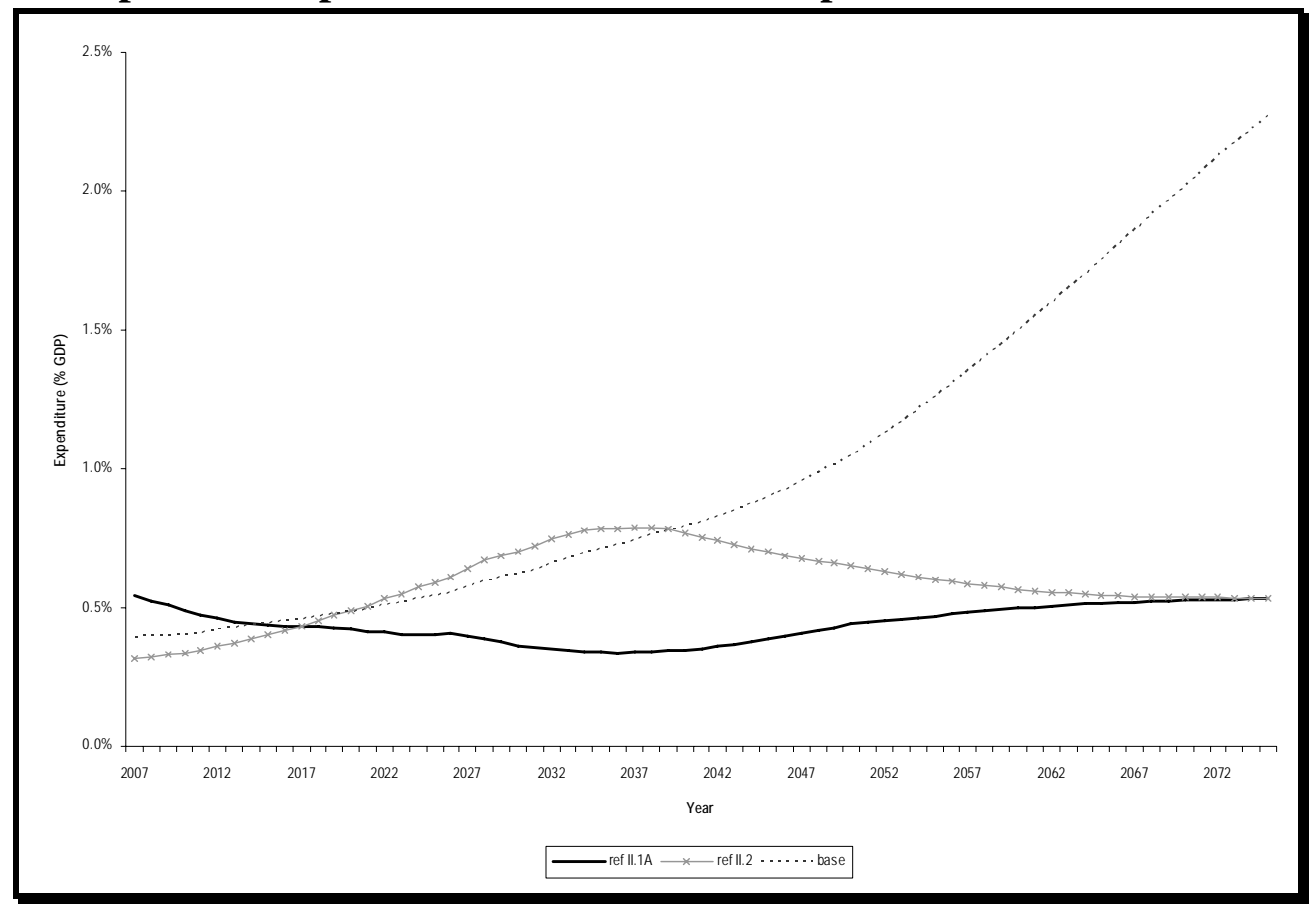

Notes: * Comparison of Government expenditure for teachers - Reform II.1A, II.2 with baseline (as \% of GDP).

Source: WB calculations based on PROST.

It is very important to notice that Figure 34 is identical to Figure 26, and Figure 35 is identical to Figure 27. This indicates that since the first pillar remains in surplus throughout the simulation period, government expenditure in Reform II. 2 will be the same as in Reform I.2. Similarly, government expenditures in Reform I.1A will be the same as in Reform II.1A. The reason for this is due to the fact that when the first pillar in surplus, the only source of expenditure is represented by: 1) wages; 2) the $10 \%$ contribution rate for the government to the new scheme; and 3) the pension expenditure for the grandfathered workers under the old scheme. Wages and the $10 \%$ contribution rate are identical under all reforms modeled here. However, the pension expenditure for the grandfathered workers under the old scheme is identical, for given expected rate of return on assets, respectively in Reforms I.2 and II.2, and in Reforms I.1A and II.1A. This is because the grandfathering rules are the same. Expenditure will be identically higher than in Reforms II.2A and I.2 because workers who are active on the date of reform will continue accruing pension rights until they retire under the old, more generous, rules.

While the hybrid and pure DC have the same impact on pension expenditure (for given grandfathering rules, of course), the hybrid is likely to produce higher replacement rates than the pure DC reform With gradual transition, replacement rates for non switchers are the same as for non switchers in the pure DC reform. This is true because accrued rights are calculated in the same way. However, for switchers replacement rates will be higher in the hybrid reform option, especially for lower income groups, due to the insurance 
component of the defined benefit first pillar. The following figure reports replacement rates for the stock of retirees in Reform II.2.

Figure 36: Comparison of replacement rates* for civil servant switchersReform II.2 with Reform I.2

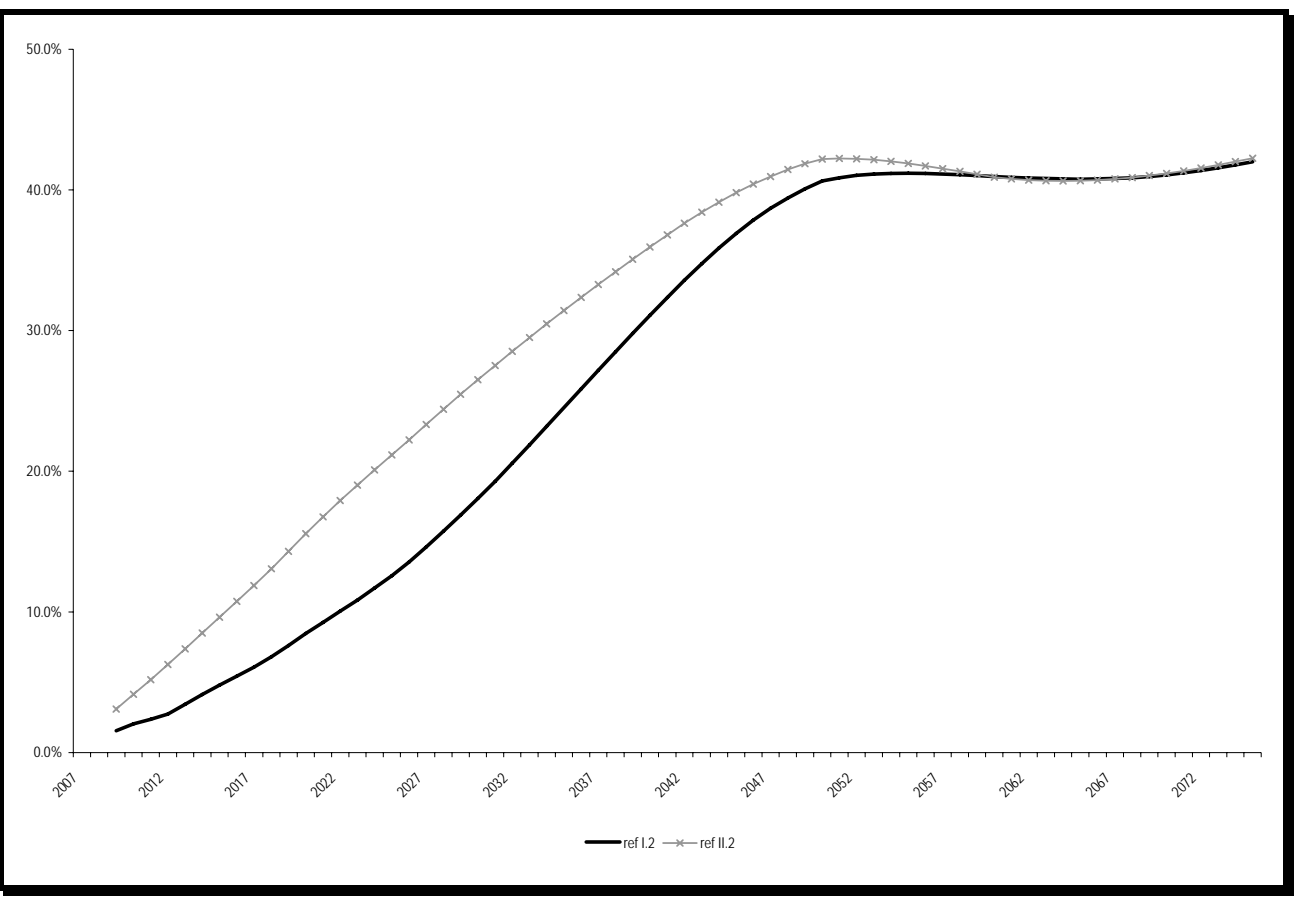

Notes: * Average pension as percentage of average group wage

Source: WB calculations based on PROST. 
Figure 37: Comparison of replacement rates* for teacher switchersReform II.2 with Reform I.2

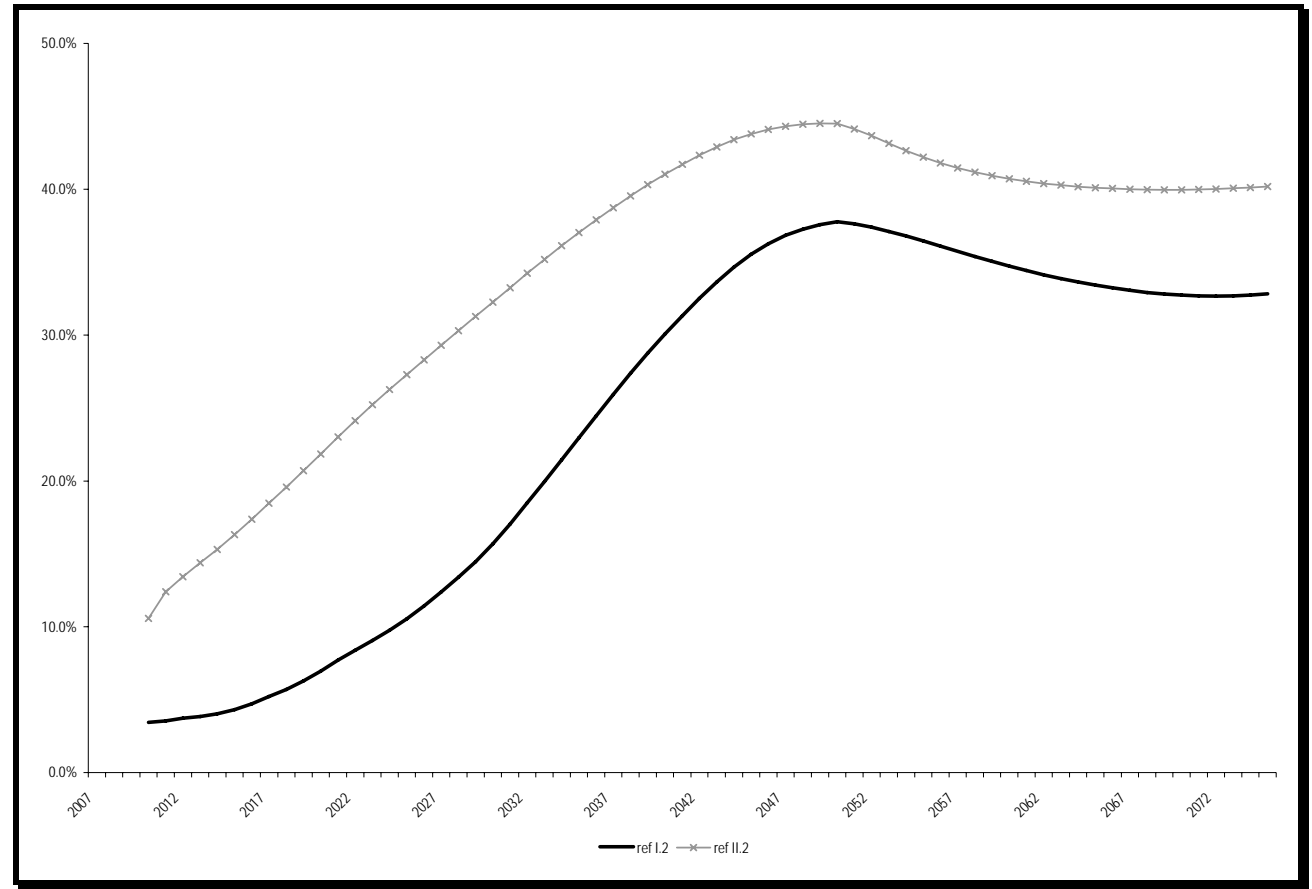

Notes: * Average pension as percentage of average group wage

Source: WB calculations based on PROST

With the similar cost to the government, the two-pillar approach may be more beneficial for lower income members through the redistributive defined benefit component and for all income groups by reducing investment risks for plan members.

\section{CONCLUSIONS AND POLICY RECOMMENDATIONS}

This paper analyzes the future liabilities that the Ugandan Public Service Pensions Fund might accumulate under the provisions of CAP 286, unless it is reformed over a period of 70 years. The results for the baseline (no-reform) scenario clearly show that the current public sector scheme is not sustainable and needs reforming. The system already imposes a heavy burden on government finances and the society at large, and, if no changes are made to it in the near future, the fiscal pressure will continue to grow exponentially thus increasing the risk of system's default on its promises.

These conclusions are, of course, very well known to Ugandan policy makers. It is less known, however, how generous the PSPF scheme is and how much it costs to the tax payer. Section IV provides a quantitative assessment of these issues. Under specific economic, demographic and recruitment assumptions discussed in APPENDIX A and agreed upon with Ugandan officials and policy makers, the system is analyzed in terms of replacement rates, government expenditure, contributions required to rebalance the scheme, and the implicit pension debt. 


\section{Table 13: Summary policy considerations under alternative reform options / 1}

\begin{tabular}{|c|c|c|}
\hline \multirow{3}{*}{ 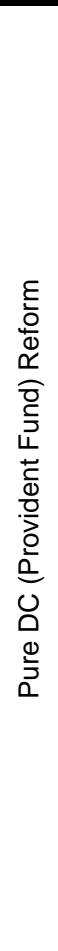 } & $\begin{array}{l}\text { Fiscal } \\
\text { impact }\end{array}$ & $\begin{array}{l}\text { Fully contributory reform. The pure provident fund reform with immediate switching and price } \\
\text { indexation for switchers has the strongest impact on government expenditure, identical to the } \\
\text { hybrid with same grandfathering rules. Tax revenues will only needed to pay for wages, } 10 \% \text { of } \\
\text { contributions, and accrued rights under the old scheme. Government expenditure is expected to } \\
\text { decrease in the short term and increase again to about } 1 \% \text { of GDP in the long run. If more generous } \\
\text { grandfathering rules are adopted government expenditure will increase proportionally. }\end{array}$ \\
\hline & $\begin{array}{l}\text { Benefit } \\
\text { adequacy }\end{array}$ & $\begin{array}{l}\text { The pure provident fund reform with immediate switching and price indexation for switchers } \\
\text { reduces average expected replacement rates more than the hybrid reform with same } \\
\text { grandfathering rules. These are expected to fall rapidly to around } 42 \% \text { for civil servants and } 33 \% \text { for } \\
\text { teachers in the high interest rate scenario of } 5 \% \text { real for the next } 70 \text { years. If more generous } \\
\text { grandfathering rules are adopted, average replacement rates will increase proportionally but only in the } \\
\text { short and medium term. }\end{array}$ \\
\hline & $\begin{array}{l}\text { Other risks } \\
\text { and } \\
\text { benefits }\end{array}$ & $\begin{array}{l}\text { Weak governance may expose accumulated funds to under political influence. Under a more } \\
\text { realistic scenario of } 3 \% \text { real return replacement rates are expected to fall to about } 27 \% \text { for civil } \\
\text { servants and about } 21 \% \text { for teachers. } \\
\text { Members fully bear investment risk. } \\
\text { The scheme provides no longevity insurance. In addition, if members were to voluntarily annuitize } \\
\text { cash balances, they would bear annuitization risk. The current financial market institutions are unable } \\
\text { to safely provide private sector annuities. } \\
\text { The pure provident fund reform rapidly lowers expected replacement rates, thus not appealing to } \\
\text { current workers, including members of Parliament. } \\
\text { Capacity of MPS needs strengthening to forecast pension expenditure in the short run and manage } \\
\text { the new scheme including outsourcing of asset management }\end{array}$ \\
\hline \multirow{3}{*}{ 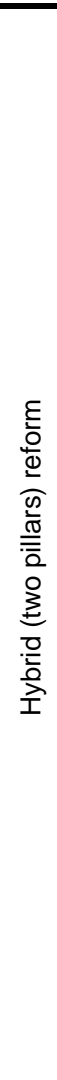 } & $\begin{array}{l}\text { Fiscal } \\
\text { impact }\end{array}$ & $\begin{array}{l}\text { Fully contributory reform. The hybrid reform with immediate switching and price indexation for } \\
\text { switchers has the strongest impact on government expenditure, identical to the pure provident } \\
\text { fund reform with same grandfathering rules as long as the first pillar is not in deficit. Tax } \\
\text { revenues will only needed to pay for wages, } 10 \% \text { of contributions, and accrued rights under the old } \\
\text { scheme. Government expenditure is expected to lower in the short term and increase to again to } \\
\text { about } 1 \% \text { of GDP in the long run. If more generous grandfathering rules are adopted government } \\
\text { expenditure will increase proportionally. }\end{array}$ \\
\hline & $\begin{array}{l}\text { Benefit } \\
\text { adequacy }\end{array}$ & $\begin{array}{l}\text { Average expected replacement rates in the hybrid reform with immediate switching and price } \\
\text { indexation for switchers are higher than in the pure provident fund reform with same } \\
\text { grandfathering rules. It will provide long run expected replacement of about } 42 \% \text { and about } 40 \% \text { for } \\
\text { civil servants and teachers, respectively, in the high rate of return scenario of } 5 \% \text { real for the next } 70 \\
\text { years. }\end{array}$ \\
\hline & $\begin{array}{l}\text { Other risks } \\
\text { and } \\
\text { benefits }\end{array}$ & $\begin{array}{l}\text { Weak governance may expose accumulated funds to undue political influence. Under a more } \\
\text { realistic scenario of } 3 \% \text { real return on assets, replacement rates are expected to fall to about } 34 \% \text { for } \\
\text { civil servants and } 35 \% \text { for teachers. These are still higher than the expected replacement rates } \\
\text { projected in the pure provident fund reform under the same interest rate scenario. } \\
\text { DB parameters (benefit indexation, contribution ceiling indexation and benefit formula parameters) } \\
\text { can be easily manipulated unless MPS develops strong modeling capacity to provide quantitative } \\
\text { answers to policy reform alternatives. } \\
\text { The hybrid reform provides a minimum longevity insurance unobtainable in the private sector. } \\
\text { The hybrid reform reduces the exposure of members to investment risk. } \\
\text { The hybrid reform ensures a more gradual transition to lower replacement rates, thus appealing } \\
\text { more to current workers, including members of Parliament. } \\
\text { Capacity of MPS needs strengthening to forecast pension expenditure in the short and long run for } \\
\text { the DB component, will need to manage a more complex scheme including outsourcing of asset } \\
\text { management }\end{array}$ \\
\hline
\end{tabular}

Notes: 1/ This is a summary of 7 alternative reform options discussed in the text. All numbers reported are indicative and would vary according to the specific scenario chosen. We refer to the text for a complete discussion of all the results. 
This paper then discusses alternative reform options that can be used as input in designing an educated homegrown reform of the fund. The paper supports a hybrid (twopillar) reform option composed by a small defined benefit scheme and a complementary defined contribution scheme, instead of a pure defined contribution (monopillar) reform option discussed by policymakers in the country. The main reason for this is related to the fact that hybrid and pure defined contribution reforms will have the same impact on reducing pension expenditure (for same grandfathering rules and as long as the first pillar is not in deficit). In addition, everything else being equal, the hybrid reform is likely to produce higher average replacement rates due to the redistributive and pooling properties of the small DB pillar. The main advantages and disadvantages of the two reform options are summarized in the previous table.

\section{Reforming the PSPF into a pure provident fund.}

Reforming the PSPF into a pure provident fund with immediate switching of current workers and price indexation of benefits has the strongest impact in relieving fiscal pressure in the medium and long run. Government expenditure is expected to remain constant at around 1\% of GDP over the whole simulation period. Notice, however that the fiscal impact is identical under the hybrid reform option for same grandfathering rules.

At the same time, replacement rates would also decrease very rapidly. In the scenario with a high rate of return on assets replacement rates for the flow of retirees gradually decrease to $60 \%$ of average wage in the long run, less in the low rate of return scenario. Price indexation would further reduce replacement rates to $40 \%$ to $50 \%$ of average wage for the stock of retirees. Members of Parliament, currently not covered by any scheme, will need to join the reformed scheme and may not support a reform that reduces benefits too rapidly. Finally, current civil servants may oppose, through lobbying, and even stall the reform process while seeking a compromise between budget alleviation and pension adequacy.

The provident fund option entails also some important risks. Replacement rates purely depend on realized returns on accumulated assets. A high rate of $5 \%$ real return on assets over the next 70 years is needed to support average replacement rates of $40 \%$ to $50 \%$ unless the covered population is prepared to contribute more than $15 \%$ of wages. This sustained high rate of return is considered unrealistic if the past experience of NSSF is taken as an example of the probable performance of the new scheme. Hence, it will be likely that ex post replacement rate will be much lower than what targeted, making the provident fund reform option undesirable from the point of view of benefit adequacy. In our simulations, the use of a 3\% real return reduces end of period expected replacement rates for civil servants and teachers to $27 \%$ and $21 \%$, respectively.

Though in relative terms a $40 \%$ to $50 \%$ replacement rate appears to be adequate, it implies rather low benefits in absolute terms (money value) as wages in the public sector are very low when compared to the economy wide average. This indicates that the reform of the PSPF should be accompanied by a reform of the civil service. The lack of progress in the comprehensive reform of the civil servant remuneration and hiring policy, together with the serious governance problems experienced by the NSSF in the past make 
a pure DC reform of the PSPF impractical. All this strongly suggests two related policy recommendations:

A. a reform of the civil servant salary structure needs considering at the same time as the reform of the PSPF so that pay and pensions are considered integral, rather than separate, elements of compensation; and

B. a pure DC reform, irrespective of the switching patterns, should not be considered by the Ugandan authorities due to the inadequate retirement benefits that it is likely to produce.

\section{Reforming the PSPF into a two pillar scheme.}

The hybrid or two-pillar reform option mitigates some of the undesirable properties of the provident fund option. The hybrid reform will provide higher expected replacement rates than the pure provident fund option due to the redistributive and pooling (insurance) properties of the small defined benefit first pillar. At the same time, the hybrid reform has the same impact in reducing government expenditure for given grandfathering rules. The reason for this is due to the fact that when the first pillar is not in deficit, the only source of government expenditure is represented by: 1 ) wages; 2 ) the $10 \%$ contribution rate for the government to the new scheme; and 3) the pension expenditure for the grandfathered workers under the old scheme. Wages and the $10 \%$ contribution rate are identical under both reform options. Hence, pension expenditure is only determined by the grandfathering rules that policymakers will adopt. Immediate switching with price indexation of benefits has the strongest impact in reducing pension expenditure. Allowing only new entrants to join the new scheme will have the weakest impact in reducing government expenditure.

In addition, the hybrid reform provides other benefits. It provides a minimum annuity benefit, hence longevity insurance, in an environment not likely to be able to safely support privately managed annuities for the foreseeable future. It facilitates the introduction of a sort of a minimum pension over the long run due to the effect of price indexation of the ceiling on contributions to the defined benefit component. It has better risk sharing properties when compared with the pure provident fund reform option as it maintains a modest intergenerational risk sharing dimension.

The hybrid reform also entails risks. The presence of a DB component leaves the door open for manipulation of DB parameters: especially of the benefit indexation, contribution ceiling indexation and defined benefit formula parameters. This risk should be mitigated by increasing the preparation and influence of MPS staff in analyzing the impact of pension variables and requiring their technical input in amending laws and regulations affecting the scheme. In addition, and similarly to the pure provident fund option, it entails the risk that poor governance of asset management will produce unsatisfactory average rates of return. This second risk is partly mitigated by the presence of a DB scheme.

The specific switching pattern that should be introduced in this type of the reform warrants further investigation than what is allowed in this study. It is likely not to be reasonable for everyone to switch to the new system, especially for workers close to retirement and earnings close to the ceiling. These individuals would be accruing very 
small account balances in the DC component of the reformed scheme and high administrative costs will be incurred to maintain a high number of individual accounts with small balances. At the same time, the extreme case of introducing the new system only for new entrants is costly, possibly more than the baseline, especially in the short-to medium term. It is likely that an intermediate policy of allowing only older age workers to stay in the old system while moving younger employees in the new scheme will provide the needed compromise between the need to reduce fiscal expenditure and create political consensus in support of the reform.

The considerations made in this second part of the conclusions suggest the following policy recommendations:

A. A hybrid type of reform is more likely to provide adequate replacement rates than a pure DC reform as it provides a minimum longevity insurance that the private sector is likely not to be able to provide until the financial sector has reached a very different stage of development. The complementary DC component would grow at a lower rate giving time for financial sector development policies to be implemented.

B. The presence of a DB component leaves the door open for manipulation of DB parameters. This risk should be mitigated by increasing the preparation and influence of MPS staff in analyzing the impact of pension variables and requiring their technical input in amending laws and regulations affecting the scheme.

C. A contribution wage ceiling, indexed to prices, should be introduced to gradually reduce contributions to the DB component in line with ageing of the covered population and the development of the financial market. Ultimately, the effect of this policy would be to introduce a minimum pension for civil servants.

D. Careful modeling will be needed to select those grandfathering rules that adequately trade-off the need to reduce government expenditure with the need to create political consensus in support of the reform.

The quantitative comparison of key indicators under all the different reform options and variants modeled in this paper is summarized in the next table: 
Table 14: Summary of the key performance indicators for alternative reform scenarios

\begin{tabular}{|c|c|c|c|c|}
\hline & & Scenarios & $\begin{array}{l}\text { Replacement rate, \% of group } \\
\text { average wage* } \\
\text { (government/teachers) }\end{array}$ & $\begin{array}{l}\text { Government } \\
\text { expenditures, } \\
\% \text { of GDP* }\end{array}$ \\
\hline & Baseline & Existing DB scheme & $68 / 70 \%$ & $4.5 \%$ \\
\hline \multirow{3}{*}{ 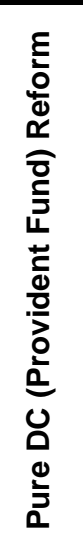 } & Reform I.1 & $\begin{array}{l}\text { Pure DC reform with immediate switching. Price indexation } \\
\text { for switchers and current retirees. } \\
\text { Variant I.1.A: high rate of return on assets } \\
\text { Variant I.1.B: low rate of return on assets }\end{array}$ & $\begin{array}{l}42 \% / 33 \% \\
27 \% / 21 \%\end{array}$ & 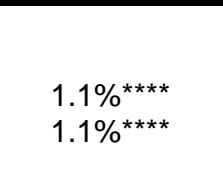 \\
\hline & Reform I.2 & $\begin{array}{l}\text { Pure DC reform for only new entrants with wage indexation } \\
\text { for grandfathered employees and current retirees. Price } \\
\text { indexation for switchers. Assumed high rate of return on } \\
\text { assets. }\end{array}$ & $42 \% / 33 \%$ ** & $1.1 \%$ ** \\
\hline & Reform I.3 & $\begin{array}{l}\text { Pure DC reform for only new entrants with price indexation } \\
\text { for grandfathered employees and current retirees. Price } \\
\text { indexation for switchers. Assumed high rate of return on } \\
\text { assets. }\end{array}$ & $42 \% / 33 \%$ *** & $1.1 \% \%^{\star \star \star}$ \\
\hline \multirow{2}{*}{ 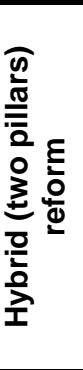 } & Reform II.1 & $\begin{array}{l}\text { Hybrid reform with immediate switching. Price indexation for } \\
\text { switchers and current retirees. Assumed high rate of return } \\
\text { on assets. } \\
\text { Variant II.1.A: high rate of return on assets } \\
\text { Variant II.1.B: low rate of return on assets }\end{array}$ & $\begin{array}{l}42 \% / 40 \% \\
34 \% / 35 \%\end{array}$ & $\begin{array}{l}1.1 \% \text { } 1 \% \star \star \star \\
1.1 \% \star \star \star \star\end{array}$ \\
\hline & Reform II.2 & $\begin{array}{l}\text { Hybrid reform for only new entrants with wage indexation for } \\
\text { grandfathered employees and current retirees. Price } \\
\text { indexation for switchers. Assumed high rate of return on } \\
\text { assets. }\end{array}$ & $42 \% / 40 \%$ & $1.1 \%$ \\
\hline
\end{tabular}

Notes: * In the long run (towards the end of the simulation period); ** Though in Reform I.2 replacement rates and expenditures at the end of the simulation period are the same as in Reform I.1.A, they are higher in the interim due to gradual transition to the new system (see Figures 26-29); *** Though in Reform I.3 replacement rates and expenditures at the end of the simulation period are the same as in Reform I.2, they are lower in the interim due to price indexation of pensions (see Figures 30-33); **** Government expenditure is identical under reforms I.1 and II.1 and under I.2 and II.2, respectively. 


\section{Other important considerations}

In all reform options assets will be accumulated over a period of time that largely exceeds the simulation period. Weak governance standards raise concerns about the sense of reform proposals that imply rapid accumulation of assets. Within the pure defined contribution reform proposal this issue can be addressed by reducing the contribution rate to the reformed scheme. Accumulated assets will be lower but so also the replacement rates. Within the hybrid reform proposal this issue can be addressed by either varying the relative size and the design of the defined benefit and defined contribution components or by varying the rate of decay of the contribution ceiling (or both). In this way an acceptable balance can be found with respect to costs versus adequate pension and with respect to different types of risks related to the types of pillars. Obviously, a trade-off exists between keeping a pension scheme unfunded or partially funded to address governance concerns and the fiscal pressure that this policy option creates on government finances.

The administration of the reformed scheme will require drastically improved data quality relatively to what we have been allowed to use for this study.

Finally, our study aimed at carefully describing the result of important policy/design choices including, but not limited to: 1) alternative retirement benefit financing mechanisms; 2) switching patterns; and 3) indexation mechanisms. The Ugandan authorities would need to further refine the analysis to develop home grown reform options that satisfy the equity, economic, financial, and political economic constraints in Uganda. For instance, an analysis of replacement rates for individual workers with different characteristics would allow policy makers to ascertain benefit adequacy for other workers beyond the average, representative, worker.

These last considerations suggest the following final policy recommendations:

A. Governance of public pension fund management needs improving independently of whether the PSPF scheme is reformed or not.

B. Rapid progress needs achieving in implementing the integrated personnel and payroll system project.

C. Careful considerations need to be made regarding the data requirement for administering the new scheme.

D. Refinement of the analysis carried out in this study is warranted by the Ugandan authorities. This would enable the finalization of a home grown reform option and improved assessment of benefit adequacy for different types of workers.

Irrespectively of the reform that the Ugandan authorities will implement capacity within MPS will need to be strengthened to manage the reformed scheme. This will entail improving quality of data, creating adequate IT infrastructure, creating modeling capacity to forecast pension expenditure and liabilities or to advise policymakers on eventual reforms that will inevitably be carried out in the future. It is crucial that any future reform will only be adopted on the basis of well understood and accepted quantitative projections. 


\section{REFERENCES}

[1] Callund, David, 2004, Pension Reform - Charting a Way Forward. Processed

[2] Deloitte and Touche, 2001 Review of Public Pension Arrangements. Processed.

[3] GOU, 2005, National budget framework paper for financial years 2005/06 2007/08. Processed.

[4] Holzmann, Robert, Robert Palacios, and Asta Zviniene, 2004, Implicit Pension Debt: Issues, Measurement and Scope in International Perspective. Social Protection Discussion Paper.

[5] Lienert, I. and J. Modi, 1997, A Decade of Civil Service Reform in sub-Saharan Africa, Working Paper 97/179, International Monetary Fund: Washington DC.

[6] MPS, 2001, Baseline survey of the trends and impact of HIV/AIDS on the public service in Uganda. Processed.

[7] MPS, 2003, Implementation roadmap for the integrated personnel and payroll system. Processed

[8] MPS, 2005 An update of public service pay reform policy. Processed.

[9] Palacios, R. and Whitehouse, E., 2006, Civil-Service Pension Schemes Around the World. Social Protection Discussion Paper.

[10] STG, 2003, The Tripartite Consultative Process Policy Recommendations and the Way Forward.

[11] World Bank, 2001, India: The Challenge of Old Age Income Security, Paper No. 22034-IN, World Bank: Washington DC 
An Assessment Of Reform Options For The Public Service Pension Fund In Uganda

\section{APPENDIX A PROJECTION METHODOLOGY AND KEY ASSUMPTIONS}

\section{Projection methodology}

Financial projections were carried out for the Public Service Pension Fund of Uganda under a no-reform scenario (baseline scenario) to assess pension liabilities of the current system assuming it does not change. Also, several reform scenarios were modeled and evaluated using the baseline scenario as a benchmark.

The World Bank Pension Reform Options Simulation Toolkit (PROST) model, version 12, was used for the projections. PROST is a computer-based pension model designed to simulate the behavior of pension systems and assess their financial sustainability under different economic and demographic assumptions over a long time frame. The model can be adapted to a wide range of country circumstances and it allows us to model various types of pension reform options. A general description of the model can be found in APPENDIX D.

The simulation horizon spans from fiscal year 2003/2004 (the base year) to fiscal year $2075 / 2076$ (the ending year) - approximately a lifetime of one generation which is viewed to be an adequate length for pension system modeling. As with any simulation model, the outcome from PROST depends largely on the nature and quality of data and assumptions used in the making of projections. Three main groups of assumptions are important in pension modeling: (1) macroeconomic and labor market; (2) demographic; and (3) pension system related variables. The key assumptions used in the projections for the PSPF and summary results are presented in the next sections.

\section{Macroeconomic and covered wage growth assumptions}

Macroeconomic variables highly influence future projections. In the short- to medium term, IMF macroeconomic projections for Uganda were used for assumptions regarding GDP growth, inflation rate, and discount rate. In the long run, it is assumed that the Ugandan economy reaches a steady state with real GDP growing at about 3.5\% and inflation stabilizing at $3.5 \%$. Average wage in the private sector is assumed to increase in line with GDP per capita growth. The macroeconomic assumptions used in the simulations are summarized in Table 15. These assumptions can be considered to be a moderate economic growth scenario. It is always advisable to experiment with various scenarios for the time paths of the main economic variables (i.e., a more and/or a less optimistic economic growth scenarios) which was not done in the presented set of simulations but may be considered in the future. 
Tatyana Bogomolova, Gregorio Impavido, Montserrat Pallares-Miralles

Table 15: Macroeconomic assumptions

\begin{tabular}{|c|c|c|c|c|c|c|c|c|}
\hline Year & $2004 / 05$ & $2005 / 06$ & $2006 / 07$ & $2007 / 08$ & $2010 / 11$ & $2020 / 21$ & $2030 / 31$ & $2075 / 76$ \\
\hline Real GDP Growth & $5.4 \%$ & $6.2 \%$ & $6.1 \%$ & $6.6 \%$ & $6.0 \%$ & $6.0 \%$ & $3.5 \%$ & $3.5 \%$ \\
\hline Real GDP/Capita Growth & $2.8 \%$ & $3.6 \%$ & $3.6 \%$ & $4.1 \%$ & $3.6 \%$ & $3.9 \%$ & $2.1 \%$ & $2.7 \%$ \\
\hline Real Wage* Growth & $2.8 \%$ & $3.6 \%$ & $3.6 \%$ & $4.1 \%$ & $3.6 \%$ & $3.9 \%$ & $2.1 \%$ & $2.7 \%$ \\
\hline Inflation Rate & $5.9 \%$ & $3.5 \%$ & $3.5 \%$ & $3.5 \%$ & $3.5 \%$ & $3.5 \%$ & $3.5 \%$ & $3.5 \%$ \\
\hline Discount Rate & $5.0 \%$ & $5.0 \%$ & $5.0 \%$ & $5.0 \%$ & $5.0 \%$ & $5.0 \%$ & $5.0 \%$ & $5.0 \%$ \\
\hline
\end{tabular}

* Average wage in the private sector

Short- to medium-term assumptions regarding wage growth for the covered population were obtained from MPS (2005). The 2001 PRP set target salary levels based on the comprehensive 1999 job evaluation exercise. The 2001 PRP targeted real salary increases ranging between $41 \%$ and $78 \%$ for professional public officers at entry graduate job grades; between 19\% and 37\%for senior levels of professional and technical skilled jobs; around $17 \%$ for heads of department; and no nominal salary increase for Permanent Secretaries, directors and legal professional. ${ }^{29}$ The PRP was supposed to be implemented within the subsequent three years with target salary levels to reach $75 \%$ of private sector salary levels of equivalent categories. The implementation of the PRP was delayed due to lack of funding. ${ }^{30}$ Given the salary increases observed between 2002 and 2004, MPS expects that the 2001 PRP be implemented within 10 years.

Already with the delayed implementation, the public sector wage bill as a percentage of GDP increased between 1\% in 1987 to 5.1\% in the fiscal year 2003/05. As a way of comparison, public sector wage bill in sub-Saharan countries was just under 6\% of GDP in 1996. This ratio is marginally higher than the average 5\% observed in Asian and Latin American countries. ${ }^{31}$ The public sector wage bill as a share of current expenditure increased in Uganda from 29\% in 1996 to 38\% in the fiscal year of 2003/04. This is marginally higher than the 35\% average in Sub-Saharan countries. ${ }^{32}$

The current ratio of wage bill over GDP or current public expenditure do not suggest that the 2001 PRP can be implemented in the short run. Hence, in the PROST simulation we adopted the MPS wage growth projections until 2014/15 (Table 16).

Table 16: Assumed average wage growth for the covered population

\begin{tabular}{|c|c|c|c|c|c|c|c|c|c|c|c|}
\hline \multirow{2}{*}{$\frac{\text { Year }}{\text { Real Average Covered Wage* Growth }}$} & $2004 / 05$ & $2005 / 06$ & $2006 / 07$ & $2007 / 08$ & $2008 / 09$ & $2009 / 10$ & $2010 / 11$ & $2011 / 12$ & $2012 / 13$ & $2013 / 1$ & $2014 / 15$ \\
\hline & & & & & & & & & & & \\
\hline Government employees & $1.2 \%$ & $3.6 \%$ & $2.0 \%$ & $1.9 \%$ & $1.9 \%$ & $1.9 \%$ & $2.0 \%$ & $1.9 \%$ & $1.9 \%$ & $1.9 \%$ & $1.4 \%$ \\
\hline Teachers & $3.0 \%$ & $5.4 \%$ & $3.2 \%$ & $3.2 \%$ & $3.1 \%$ & $3.0 \%$ & $3.0 \%$ & $2.9 \%$ & $2.8 \%$ & $2.8 \%$ & $2.8 \%$ \\
\hline eal Private Sector Av.Wage Growth & $2.8 \%$ & $3.6 \%$ & $3.6 \%$ & $4.1 \%$ & $3.9 \%$ & $3.7 \%$ & $3.6 \%$ & $3.6 \%$ & $3.6 \%$ & $3.7 \%$ & $3.7 \%$ \\
\hline
\end{tabular}

Reaching the target $75 \%$ of the private sector salary level in the long run would require under the above macroeconomic assumptions - an average annual growth of wages in the public sector by about $4 \%$ (real) over a period of 60 years which does not seem to be

${ }^{29}$ For details of background and rationale supporting our wage growth assumptions see MPS (2005)

${ }^{30}$ The projected funding gap for the fiscal year 2006/07 is already UGS 75 billion, or $9 \%$ of projected wage bill.

${ }^{31}$ See MPS (2005).

${ }^{32}$ See Lienert and Modi (1997). 
realistic. Therefore, for the long term, the real average covered wage growth rate was assumed to stabilize at a more moderate level of around 3\% - slightly higher than in the private sector. This resulted in an increase of the average covered wage relative to the economy wide average wage from the current about $40 \%$ and $30 \%$ to about $45 \%$ and $40 \%$ for civil servants and teachers respectively as shown in Figure 38. The assumed wage growth policy for civil servants and teachers was suggested by and discussed with officers in MPS.

Clearly, the assumption that civil servant salaries remain at a level that is less than $50 \%$ of private sector average wages for the next 75 years is also a non realistic assumption. Low wages do not allow the government to retain qualified staff and promote corruption. The reform of the PSPF should be accompanied by a review and reform of the civil servant remuneration and hiring policy. While it is important that these two reforms be carried out simultaneously, it is beyond the scope of this study to analyze options for reforming the Ugandan civil service. This analysis is left for future investigation.

Figure 38 reports the projected average wage for civil servants and teachers as a percentage of private sector average wage resulting from the above assumptions.

Figure 38: Projected civil servants average wage ( $\%$ of economy wide average wage)

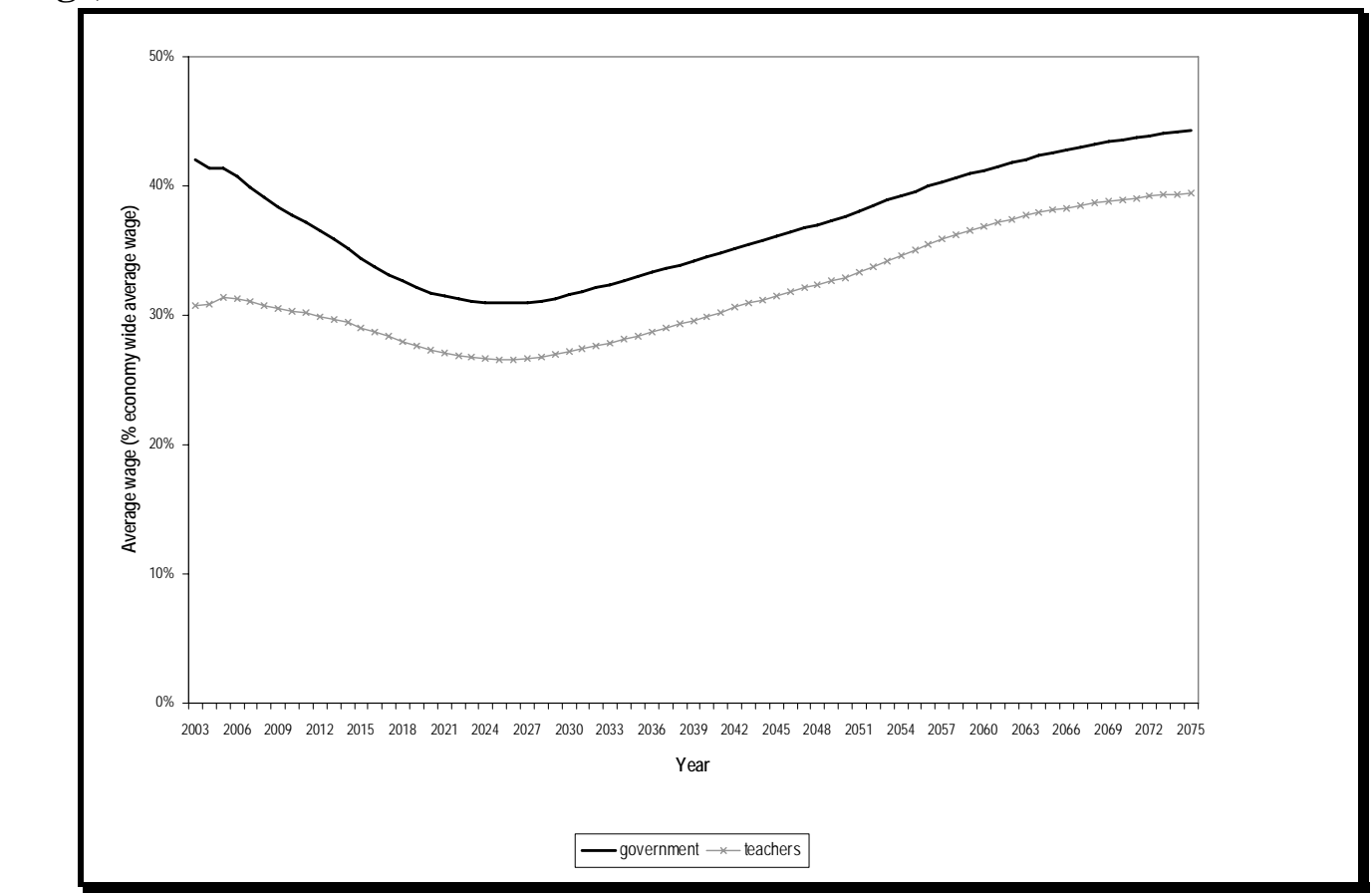

Source: WB calculations

\section{Demographic assumptions}

\section{Population Projections}

Population projections for Uganda used in the simulations were provided by the World Bank's Population Unit. In line with the observed international trends, fertility and mortality rates are assumed to decrease over time. The total fertility rate - which is currently very high by international standards (about 600\%) - is projected to gradually 
decrease over time reaching the reproduction level of about $210 \%$ by 2075 . The assumed changes in mortality rates are discussed in more detail in the next section as they play a key role not only in the population projections per se but in the projections of life expectancy for the population covered by the pension system. Based on these assumptions, the population is projected to grow from the current estimated 24 million to about 67 million by the end of the simulation period.

\section{Mortality table}

As mentioned above, mortality tables are very important in pension system financial projections as they determine - through life expectancy changes - how long retirees will receive their pensions. The assumed reduction in age and gender specific mortality rates result in an increase in life expectancy as reported in Table 17. The projected growth of life expectancy at birth is relatively rapid: by about 5 years over the next 15 years and by 11 years over the next 30 years, with life expectancies reaching the level currently observed in developed countries by the end of the simulation period. One of the underlying mortality assumptions used in these projections is that the current trend of declining HIV prevalence rates will continue and HIV/AIDS will not have any significant impact on future mortality rates. Our discussions with Ugandan demographers confirmed this assumption to be reasonable.

\section{Table 17: Projected life expectancy* for the general population}

\begin{tabular}{|c|c|c|c|c|c|c|}
\hline Year & 2003 & 2004 & 2005 & 2020 & 2050 & 2075 \\
\hline \multicolumn{7}{|l|}{ Male } \\
\hline Life expectancy: At birth & 42.5 & 42.8 & 43.1 & 48.2 & 59.5 & 70.4 \\
\hline At Age 20 & 32.3 & 32.6 & 32.9 & 37.0 & 45.7 & 53.0 \\
\hline At Age 60 & 13.3 & 13.3 & 13.4 & 13.7 & 15.0 & 17.5 \\
\hline At Age 65 & 10.7 & 10.7 & 10.7 & 11.0 & 12.0 & 14.0 \\
\hline \multicolumn{7}{|l|}{ Female } \\
\hline Life expectancy: At birth & 43.1 & 43.4 & 43.8 & 48.9 & 60.6 & 74.8 \\
\hline At Age 20 & 32.7 & 33.0 & 33.4 & 37.4 & 46.0 & 56.7 \\
\hline At Age 60 & 14.0 & 14.0 & 14.0 & 14.1 & 15.6 & 20.0 \\
\hline At Age 65 & 11.2 & 11.1 & 11.1 & 11.2 & 12.5 & 16.1 \\
\hline
\end{tabular}

Notes: *Average remaining years of life expected at specific ages Source: WB calculations based on PROST

In a closed group, like the PSPF, it is very likely that life expectancy of the population covered by the pension system significantly differs from that of the general population. This is often the case in developing countries where living conditions, including access to health care, for civil servants are notably better that for the majority of the population resulting in their higher life expectancy. As life expectancy for the retired population is one of the essential determinants of pension system expenditure, financial projections are very sensitive to the mortality tables used in the simulations.

Our consultations with Ugandan demographers strongly supported the idea that civil servants in Uganda might on average live longer than the non-covered population. 
However, no specific data was available to confirm this supposition. Under the circumstances, two variants of the baseline scenario were modeled to look at the sensitivity of the projections to mortality rates assumptions: 1) "baseline variant 1", using the general population mortality rates; and 2) "baseline variant 2”, assuming lower mortality rates for civil servants. Mortality data for various populations groups in India were used as a benchmark for variant $2 .^{33}$ A $70 \%$ mortality multiplier was applied to mortality rates for old age pensioners, resulting, e.g., in an increase of life expectancy for a 60 year old men in the base year by 3 years. See Table 18 for the assumed life expectancy changes in variant 2.

Table 18: Projected life expectancy for civil servants

\begin{tabular}{lccccc}
\hline Year & & $\mathbf{2 0 0 3}$ & $\mathbf{2 0 2 0}$ & $\mathbf{2 0 5 0}$ & $\mathbf{2 0 7 5}$ \\
\hline & Male & & & & \\
At Age 60 & & 16.3 & 16.7 & 18.0 & 20.5 \\
At Age 65 & Female & 13.3 & 13.6 & 14.6 & 16.8 \\
& & & & & \\
At Age 60 & 17.0 & 17.1 & 18.6 & 22.9 \\
At Age 65 & & 13.8 & 13.8 & 15.2 & 18.8 \\
\hline
\end{tabular}

Source: WB calculations based on PROST

\section{Assumptions related to system participants}

As mentioned before, this modeling exercise focused on the assessment of the system's future liabilities leaving out the existing arrears. All benefits are assumed to be paid in full starting from the base year.

The following benefits are modeled as separate categories:

- Regular pensions paid to old age pensioners;

- CPG payments to newly retired old age pensioners (all new retirees are assumed to choose the CPG and a reduced pension ${ }^{34}$ );

- Regular pensions paid to survivors.

All other benefits - gratuities paid to survivors, non-CPG gratuities and other types of benefits - are modeled in an aggregate way as pension system "other expenses". No administrative costs are assumed to be borne by the system. Since the current system is non-contributory (the liabilities uniquely financed by the central or local budgets), no revenues are modeled in the baseline scenario.

Active employees and old age pensioners are modeled by tracking each age and gender cohort over time, using the initial distributions of system participants by age and gender, the assumed hiring policy for active members, retirement probabilities and mortality

\footnotetext{
${ }^{33}$ A mortality study of annuitants conducted by the Life Insurance Corporation in India showed that, for example, life expectancy at age 55 for the covered group was 5 years higher than for the general population (see World Bank (2001))

${ }^{34}$ Ugandan experts confirmed that almost everybody chooses this option.
} 
rates. Survivors are modeled in an aggregated fashion as a fixed percentage of the total covered population.

\section{Modeling changes in the number of active employees}

Changes in the number of active employees over time are modeled with the use of the "flow" method described in APPENDIX D. Under this method, an exogenous growth rate for the total number of employees is assumed, as well as the gender and age distribution of new employees joining the pension system. Subsequently, for each year of the simulation period, projections for the number of employees in each age and gender cohort based on these assumptions, as well as on the assumed mortality and retirement rates. Currently the number of civil servants is about $0.3 \%$ of the Uganda population while the number of teachers is about $0.6 \%$. For the medium term assumptions regarding the recruitment policy (until 2014/15), we used recruitment projections contained in MPS (2005). This document discusses the pay reform policy (PRP) of 2001, analyzes the progress made in implementing it, and projects average wages and number of civil servants and teachers within a framework of the pay reform proposal. The assumptions on the growth of the total number of employed for the medium-term are summarized in the Table 19.

Table 19: Medium term active population growth assumptions

\begin{tabular}{|c|c|c|c|c|c|c|c|c|c|c|c|}
\hline Year & $2004 / 05$ & $2005 / 06$ & $2006 / 07$ & $2007 / 08$ & $2008 / 09$ & $2009 / 10$ & $2010 / 11$ & $2011 / 12$ & $2012 / 13$ & $2013 / 14$ & $2014 / 15$ \\
\hline Government & 70.3 & 69.7 & 70.0 & 70.2 & 70.5 & 70.8 & 71.0 & 71.2 & 71.3 & 71.5 & 71.7 \\
\hline Tecahers & 144.0 & 146.5 & 149.1 & 151.7 & 154.2 & 156.8 & 159.3 & 161.9 & 164.5 & 167.0 & 170.8 \\
\hline Total & 214.3 & 216.2 & 219.1 & 221.9 & 224.7 & 227.6 & 230.3 & 233.1 & 235.8 & 238.5 & 242.5 \\
\hline Growth rate-Government & $0.91 \%$ & $-0.91 \%$ & $0.39 \%$ & $0.39 \%$ & $0.39 \%$ & $0.39 \%$ & $0.26 \%$ & $0.26 \%$ & $0.26 \%$ & $0.26 \%$ & $0.26 \%$ \\
\hline Growth rate - Teachers & $1.81 \%$ & $1.78 \%$ & $1.75 \%$ & $1.72 \%$ & $1.69 \%$ & $1.66 \%$ & $1.63 \%$ & $1.61 \%$ & $1.58 \%$ & $1.56 \%$ & $1.50 \%$ \\
\hline Population growth rate & $2.55 \%$ & $2.49 \%$ & $2.46 \%$ & $2.42 \%$ & $2.39 \%$ & $2.36 \%$ & $2.34 \%$ & $2.31 \%$ & $2.29 \%$ & $2.26 \%$ & $2.24 \%$ \\
\hline
\end{tabular}

Source: PROST projections based on MPS (2005) growth rates.

Compared to other countries, the size of civil service in Uganda is rather small relative to its population. For example, in neighboring Kenya central and local government civil servants account for around $1 \%$ of population while teachers account for another $1 \%$. In Africa the average share of central civil servants (only) in population is $1.1 \%$, in Asia also 1.1\%; it's higher in Latin America - 1.5\%, and even more high in OECD countries 1.9\% (Palacios and Whitehouse 2005). Indeed a thorough benchmarking of the size of the Uganda civil service population would require comparing whether countries have a centralized or decentralized governments. Nevertheless, the comparison with Kenya (country with similar administrative structure and size of informal labor market) suggests that the size of the Uganda civil servant population is small. Based on this information, it was assumed that in the long run the share of each group - civil servants and teachers will gradually increase to around 1\% of the population by around 2050 and will grow in line with population thereafter. Compared to the observed trend around the world, this is a conservative assumption. The projected growth of the total number of active employees in each of the sub-schemes is plotted in Figure 39. 
Figure 39: Projected number of active employees (thous. persons)

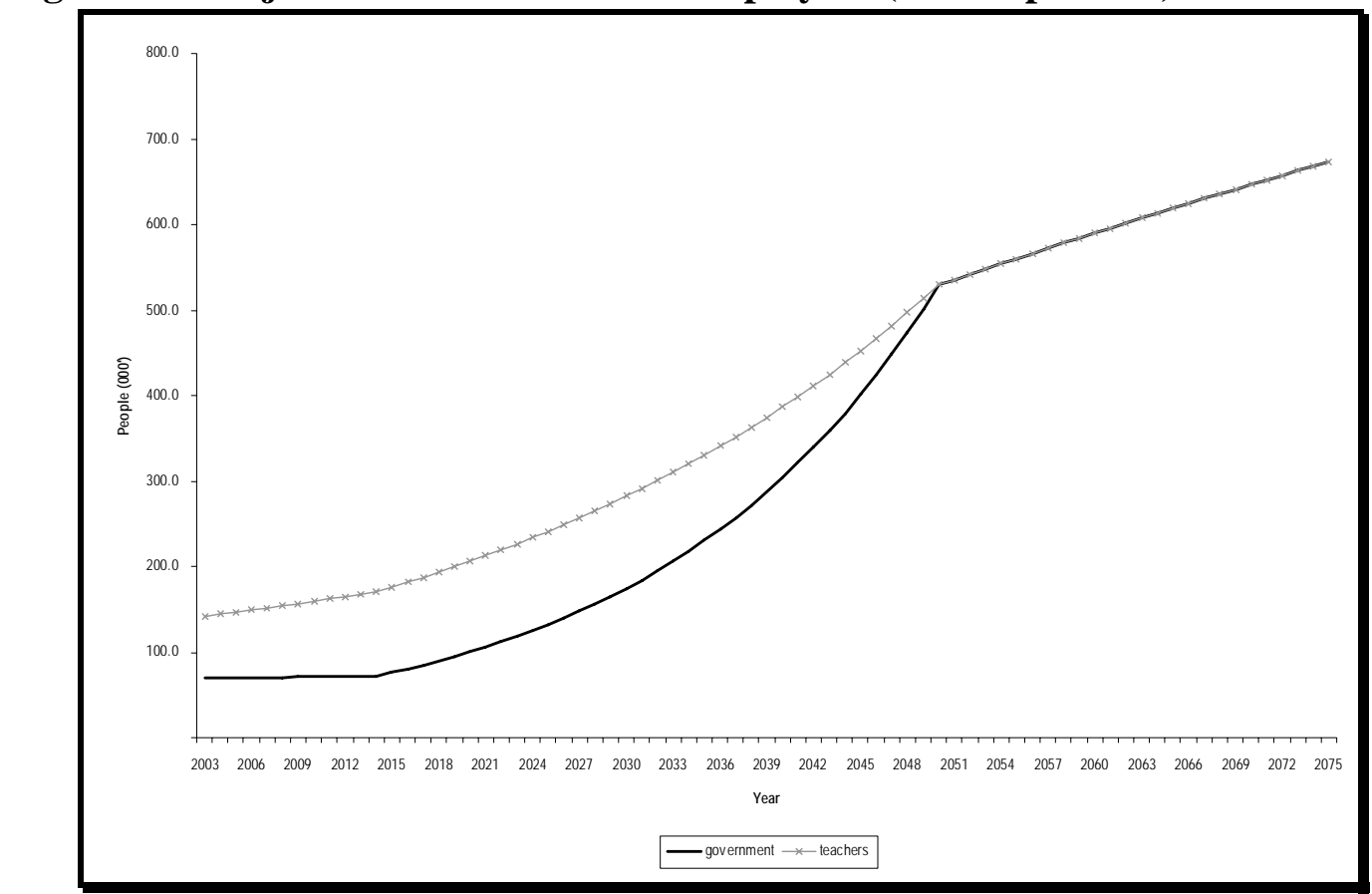

Source: WB calculation based on PROST

Changes in age and gender composition of active employees were modeled by defining the age and gender distribution of new recruits. To derive the assumed age and gender profile of new employees, the actual data were smoothed with a five year moving average and recruitment after age 49 was eliminated, as shown in Figure 40 and Figure 41 . The share of women among new recruits is lower for civil servants (31\%) than for teachers (38\%). New civil servants - both men and women - are also on average older than teachers: 33 and 31 years old for men and women, respectively among civil servants and 28 and 26 years old for men and women, respectively, among teachers. With no information on future policy regarding age and gender of newly hired employees, we assumed that in the future the age profile and the gender composition of new recruits remain the same.

A scenario with higher activity rates for women in the medium- to longer term may be considered in further simulations. The impact of the recruitment policy aimed at increasing the share of females is not obvious. On the one hand, women tend to live longer $^{35}$ and therefore collect their pensions for more years than men which may increase the overall pension liabilities in a defined benefit system. On the other hand, pension liabilities may increase to a lesser extent or even decrease if women's wages remain lower than that of men.

\footnotetext{
${ }^{35}$ For the population as a whole, female life expectancy in 2003 is $5 \%$ higher than men life expectancy. In 2075, female life expectancy is projected to be $14 \%$ higher than men life expectancy see section 0 on population mortality assumptions.
} 
Figure 40: Assumed age and gender distribution of new civil servants (\% of new recruits)

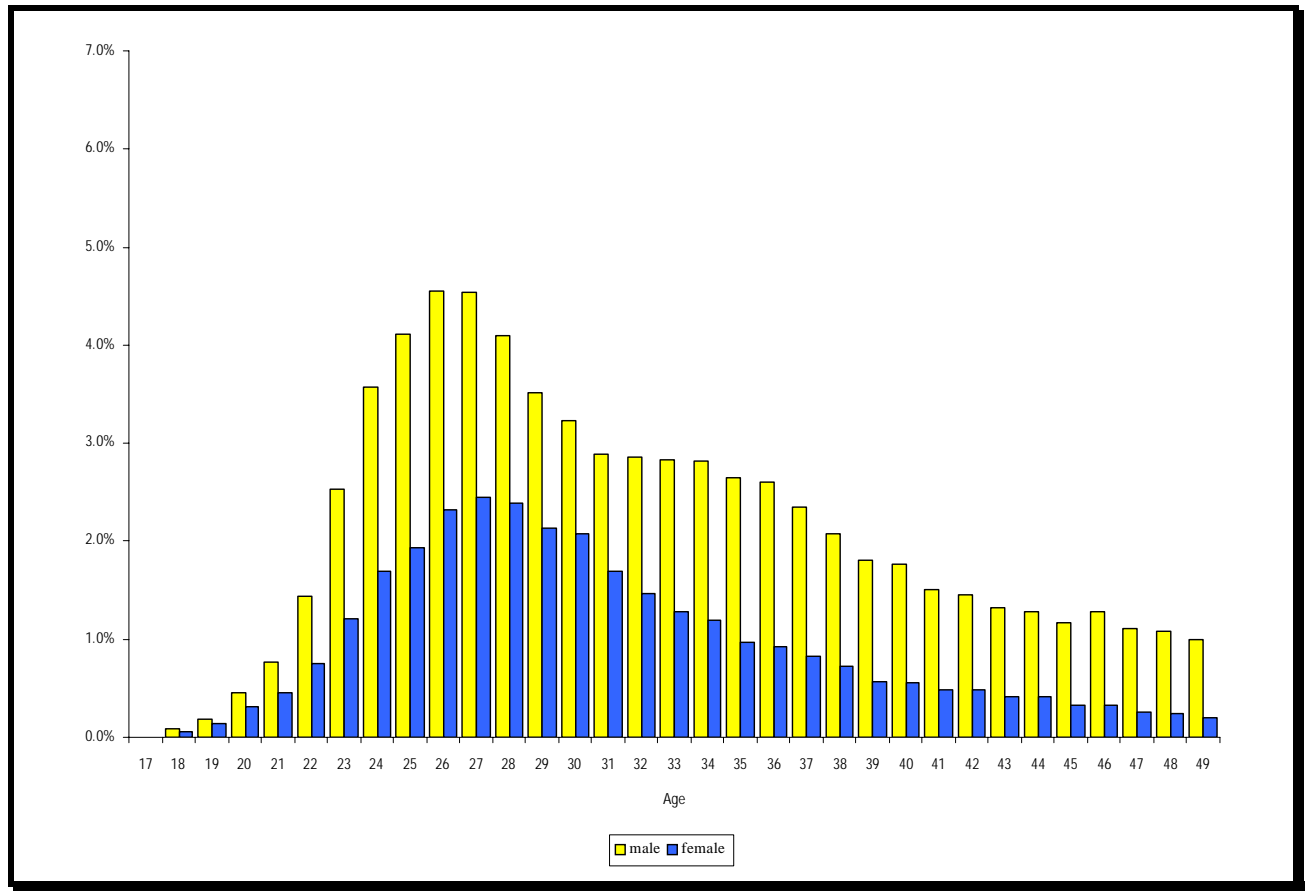

Source: WB calculations based on actual data

Figure 41: Assumed age and gender distribution of new teacher (\% of new recruits)

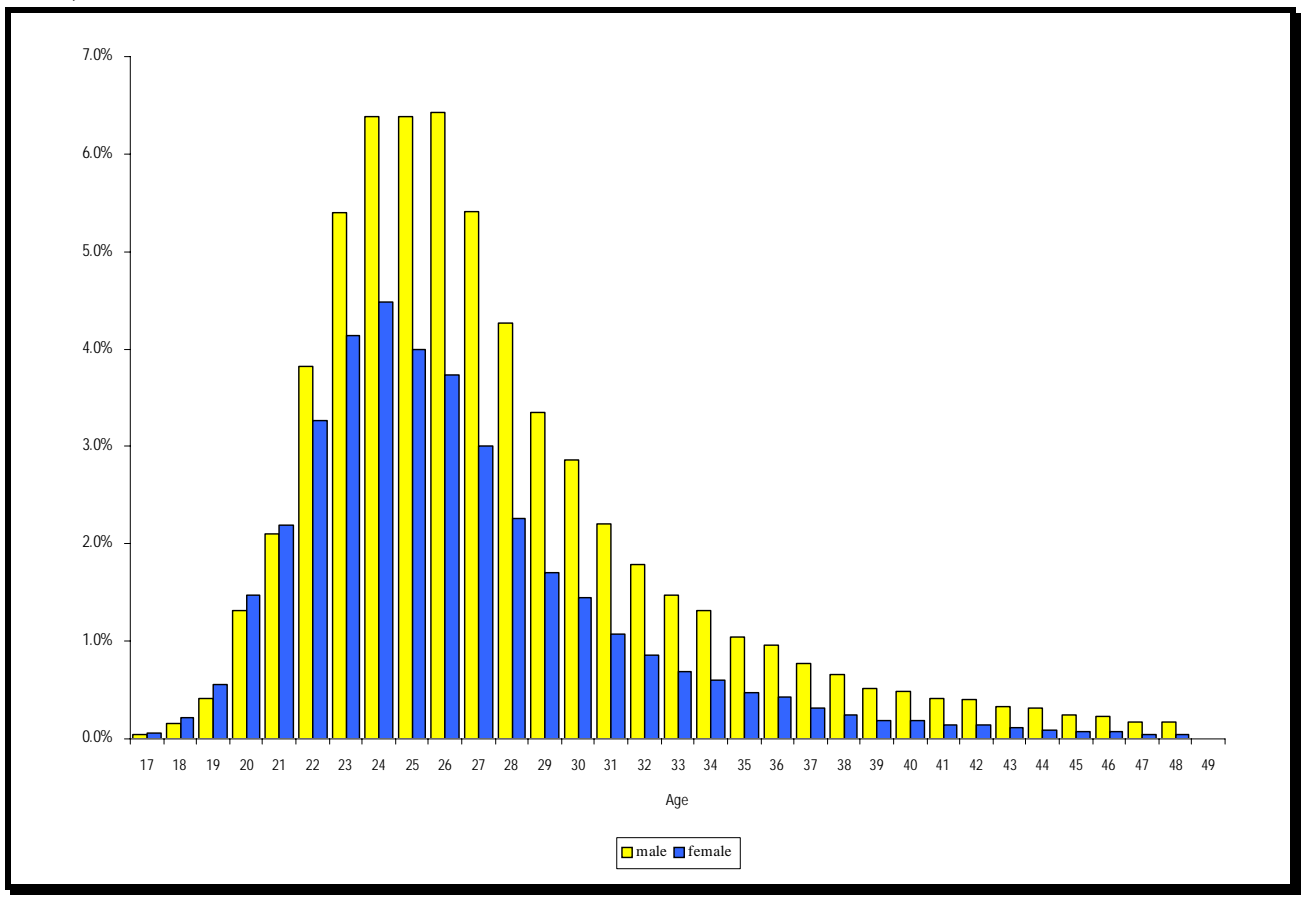

Source: WB calculations based on actual data 


\section{Modeling changes in the number of retirees}

Changes in the number of old age pensioners were modeled by using the flow method (see APPENDIX D for details) via setting the number of new retirees by age and gender as percentage of previous year's contributors. These percentages show the probability of an active employee of a particular age and gender to retire in the next year.

As mentioned in Section III.A, the available data on the flows of retirees were not segregated by beneficiary category and could only partially be used for deriving the retirement pattern for new old age pensioners. In accordance with the current law, it was assumed that individuals retire between age 45 and 61. Based on the available data for PSPF and data for some other pension schemes with early retirement arrangements, the retirement probabilities were assumed to increase with age as shown in Figure 42 and Figure 43. Same retirement pattern was used for both genders in both sub-schemes. Applying such retirement rates essentially results in the average retirement age varying within quite a narrow corridor between 53 and 54 for both genders and in both subschemes.

Figure 42: Age specific retirement probabilities* for civil servants

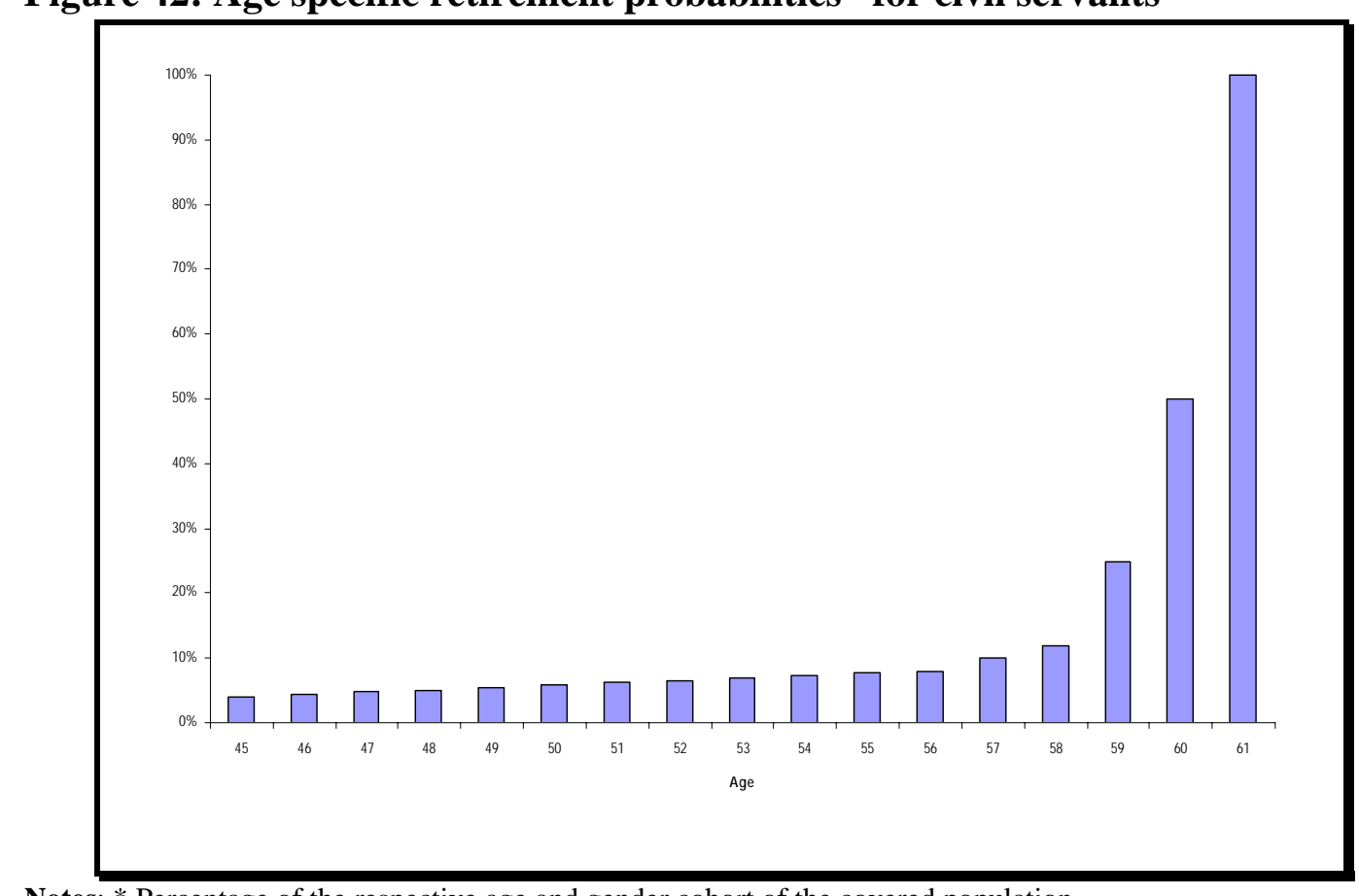

Notes: * Percentage of the respective age and gender cohort of the covered population

Source: WB calculations based on actual data

The second beneficiary category - survivors - was modeled in a more aggregated way. As there was no reason to believe that the number of survivors as a share of the total covered population will significantly change over time, it was assumed to remain at the current level of $2.7 \%$ for civil servants and $0.3 \%$ for teachers. This assumption can be reconsidered in further simulations.

The projected number of beneficiaries in each of the modeled sub-schemes is plotted in Figure 43. 
Figure 43: Projected number of beneficiaries (thous. persons)

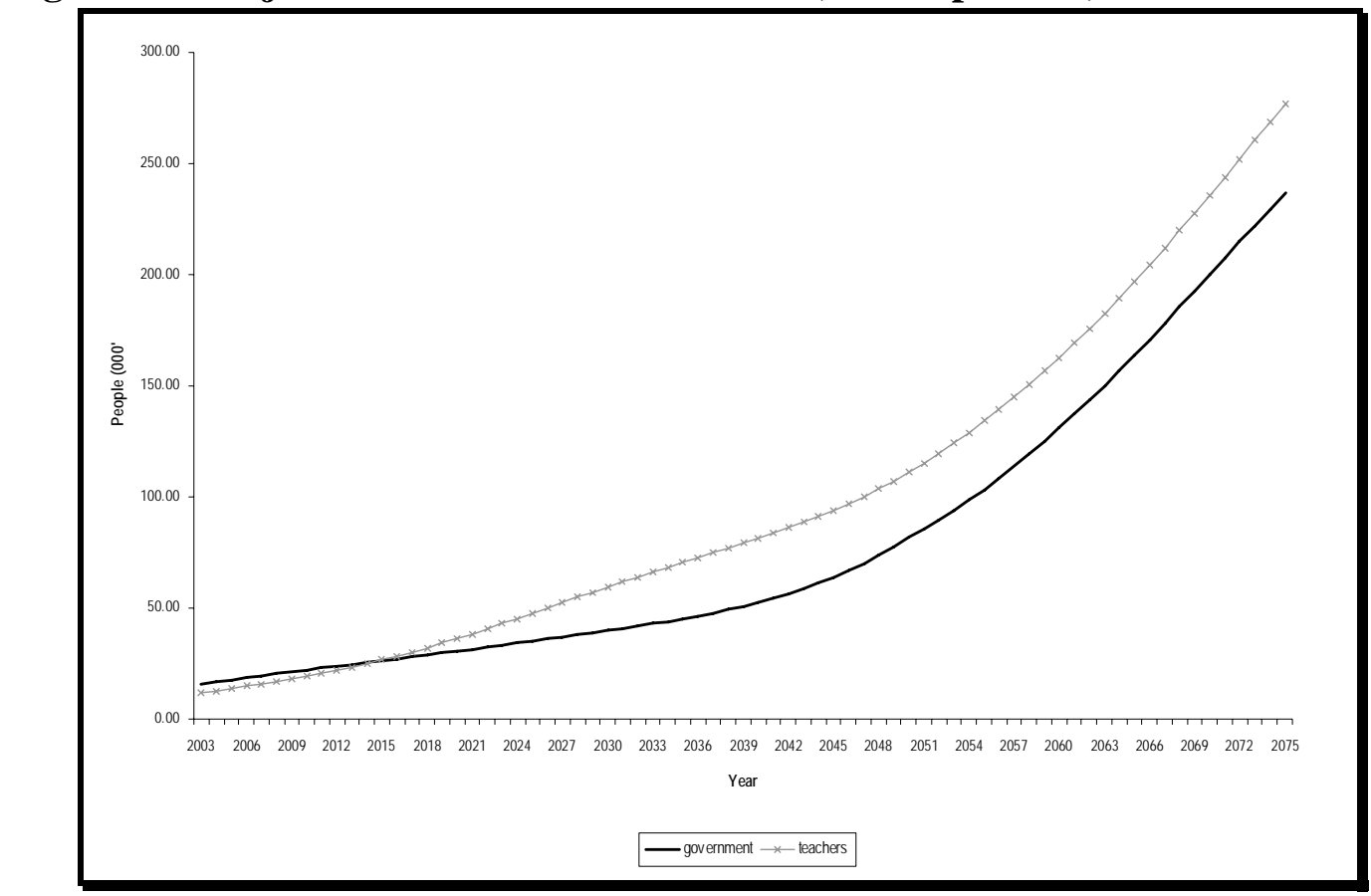

Source: WB calculations based on PROST

All assumptions used in the simulations were discussed and validated by MPS officials.

\section{Modeling benefits}

Benefits are recalculated each year by using indexation rules and adding entry pensions of new retirees. As mentioned before, in the baseline scenario it is assumed that everybody chooses a CPG and a reduced pension.

According to the current rules, pensions are indexed to wages with the indexation mechanism working as follows: wage indexation is applied to full pensions and the commuted part is not indexed, meaning that the reduced pension increases at a higher rate than the wage growth.

This mechanism was approximated by modeling a case where everybody received full pension indexed to wages and another case where everybody received $1 / 3$ of full pension not indexed at all and then subtracting appropriate second case outputs (pension payments and IPD) from the first case. This approach can take care of pensions for those who retired after the base year. Adjustments to wage indexation were used in the first years of the simulation period to take into account higher than wages growth rate for pensions of those who retired before the base year. Restoration of pensions to full pension after 15 years was modeled in a separate case and then integrated into the outputs.

Pensions for new old age retirees in the baseline scenario are modeled by applying the benefit formula currently set by law to individuals' wages and years of service at the time of retirement. CPG payments are also calculated by applying the existing formula which applies the same commutation factor of 15 to all retirees regardless of their age. Assumptions regarding years of service at retirement (Figure 44) are based on actual data 
for the last five years. The data did not show any significant difference between men versus women as well as civil servants versus teachers of the same age.

\section{Figure 44: Assumed number of years of service at retirement}

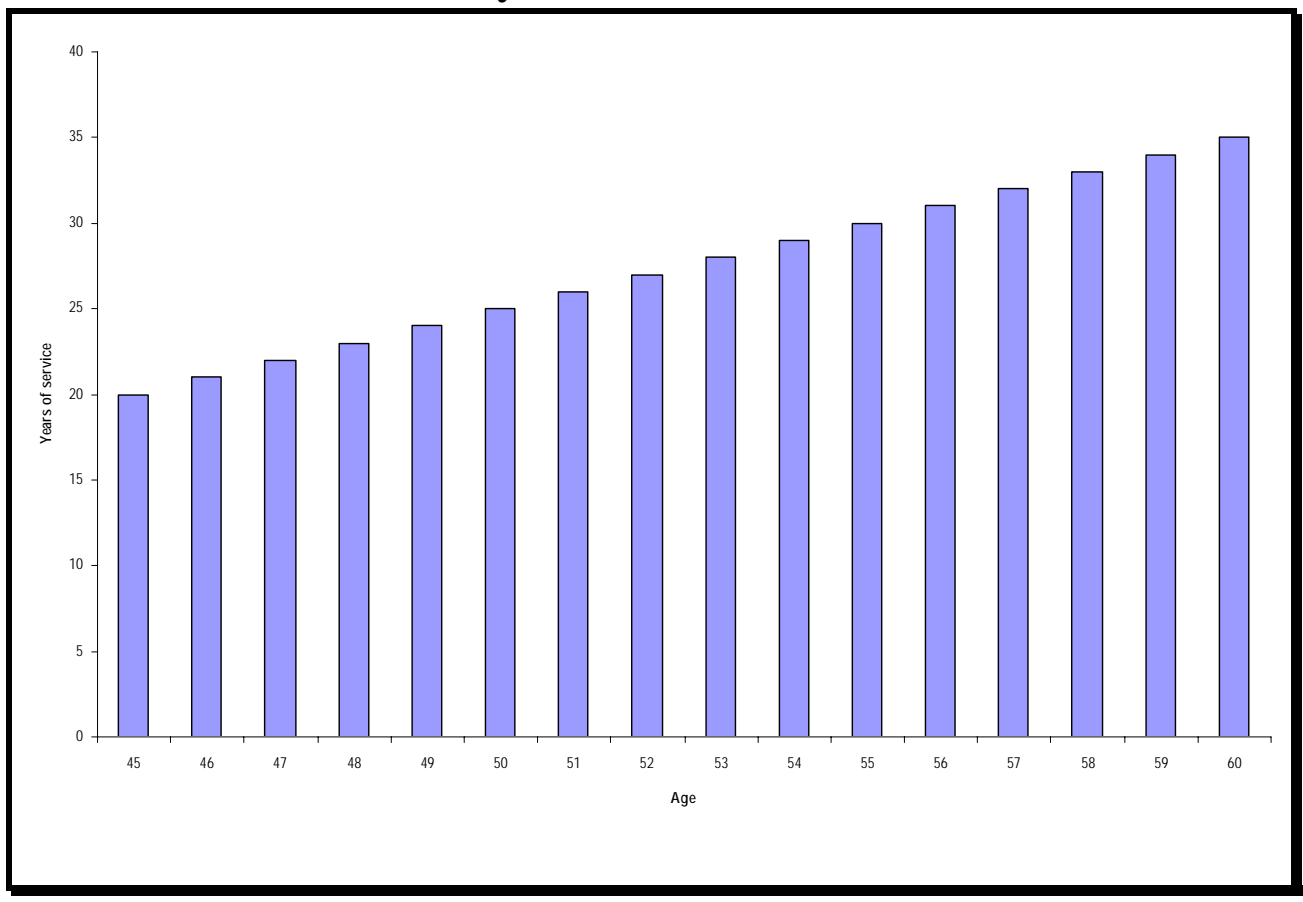

Source: WB calculations based on actual data

In accordance with the current law, survivorship benefits are modeled to be $100 \%$ of old age pensions. 


\section{APPENDIX B INTERNATIONAL EXPERIENCE ON PUBLIC SERVICE PENSIONS ARRANGEMENTS}

In many ways, the financial stresses faced by civil service pension schemes are quite similar around the world. Most countries had undergone extended periods of massive expansion of public employment, typically in the seventies and the eighties, immediately followed by periods of stabilization or even contraction in some instances. Such a phenomenon is quite evident in that the ratio of pensioners to covered employees has been rising dramatically over the last decade. This is further exacerbated by the use of liberal early retirement programs to reduce wage bill expenditure, resulting in an explosion of the pension expenditure of most countries. The Uganda public service schemes have additional problems to most other civil servants systems in the world. Besides not being a contributory system (except for the urban authorities scheme), it has been accumulated arrears for several years and is currently not paying most of the due pension benefits.

Since most of the civil service pension bill is paid (or supplemented) by government budgetary revenues, many of the solutions adopted are also similar to those of statutory national pension schemes. It is therefore not surprising that reform policies designed to manage civil service pension expenditure do not differ markedly from measures used to restore fiscal balance in national pension systems. As such, amendments/modifications to the provisions of civil service schemes that are being considered generally take the form of: (i) reducing pension liability through parametric changes (i.e., lowering benefit entitlements) ; (ii) gradually shifting a portion of the costs to the employees by increasing contribution rates (or implementing a contribution rate), or shifting towards some form of advance funding of benefit obligations; (iii) designing systems that allow greater pension portability; and (iv) harmonizing compensation components (cash pay and fringe benefits) to attract, retain and motivate civil servants.

Reduce pension liability. Many countries have undertaken steps to reduce their civil service pension liabilities by introducing higher retirement ages and/or longer service periods, increasing required employee contribution rates, lowering rates of benefit accrual, and changing the post-retirement indexation policy so that pensions will increase in accordance with price increase instead of wage increase. Korea increased the employee share of the contributions, shifted from wage to price indexation and reduced benefit levels for new hires. Italy also shifted from wage to price indexation and introduced limitations on early retirement. Greece and Portugal all reduced the benefit accrual rates. The latest reform proposals tabled by the Brazilian President included measures such as introduction of retirement ages (viz. no age requirement under current provisions), pensions based on career average earnings (instead of final wage), and levying a 11 percent tax on pensions above a certain level.

Advance funding or cost sharing with employees. Civil service pension schemes in many countries, particularly in the South Asia and Africa regions, are often totally unfunded or there may be little or no reserves to back up the obligations. Of late, several countries realized the need to analyze how to achieve some level of advance funding (at least partially) of benefit obligations. This may take the form of requiring employees to contribute at a higher rate, governments to contribute systematically, and/or establishing 
reserves so that investment earnings from pension funds can reduce the ultimate cost of the schemes.

Pension portability. Historically, civil service pension schemes were established as a form of reward for long service. Hence most benefit designs for these schemes are "backloaded", with little in terms of transfer of pension rights in case of early departure to encourage lifetime employment. However, as countries develop socially and economically, what used to be reward for long service becomes a barrier to labor mobility - prohibiting the flexibility that is generally available through natural attrition to attract new blood which is vital to allow the civil service to be modernized for the $21^{\text {st }}$ century. Beginning with the 1980s, many industrialized countries realized the need for the civil service to be modernized, and started a trend to integrate civil service pension systems with national social security systems. Integration of civil service plan benefits into national social security plan benefits occurs to varying degrees in different countries. In the most complete sense of the term, total integration takes place when civil Servants are treated no differently from private sector employees, as in Argentina and Peru, and throughout eastern Europe where preferential schemes no longer exist. A less complete form of integration occurs where a civil service pension system is operated by the State much like any other occupational pension plan in the private sector. Examples of this type can be found in the United Kingdom, Japan and other industrialized countries. Overall, an increasing number of civil service plans are being integrated in one way or another into national pension systems. In countries where integration has occurred, 60 of these integrated pension system frameworks were implemented after 1980. The lack of preservation of pension rights and their full purchasing value, albeit not unique to Uganda, results in low civil service turnover, which limits the healthy intake of new talent and removal of non-performers at all levels of the civil service. To remove these disincentives, concerted international efforts to provide greater portability of pension entitlements are underway - by integrating civil servants into the national retirement income scheme or introducing defined contribution schemes, or both.

Some countries like Chile, Uruguay, Peru and Jordan have taken steps to terminate the civil service preferential scheme for new employees as part of the process of implementing pension reform for their national systems. Others such as United States and Hong Kong ${ }^{36}$ have established fully funded defined contribution schemes for new employees to allow for full portability of pension rights. The latest addition to the list of countries establishing fully-funded defined contribution schemes is India, as announced by the Finance Minister in the budget speech in February 2001, 2002 and 2003, although details of the arrangements are still not known.

Holistic civil service reform. Instead of focusing exclusively on lowering the civil servants' wage bill by downsizing the civil service workforce, an increasing number of countries have turned their efforts towards a more holistic approach - one that takes into consideration the total compensation package as well as other employment parameters. The analysis of civil service pension reform should therefore go beyond comparisons of

${ }^{36}$ United States established its fully funded defined contribution system for civil servants in 1987; Hong Kong introduced amendments so that new entrants into the civil service will now be covered under the newly established defined contribution arrangement (2001) as well as the Mandatory Provident Fund for private sector workers. 
civil service pension provisions or cost-sharing arrangements between the State (as the employer) and the employee. In order to gain a better understanding of the pension reform situation in any country, one needs to study additional elements such as (i) publicprivate wage rates and earnings; (ii) different kinds of fringe benefits including free (or below cost) medical services; and (iii) working conditions and stability of employment. Hong Kong provides the most recent example of a region that has undergone a thorough reform of its civil service, by carefully studying its human resource policies including appointments, pay and benefits, promotion and exit policies. Such a holistic approach takes into consideration the proper apportionment between cash pay and fringe benefits, its comparability with the private sector, as well as other public sector remuneration policies around the world.

Building a trustworthy, effective and efficient civil service. As Uganda moves forward into a new era, civil servants are expected to become more efficient and effective to keep pace with the needs and demands of the communities they serve. It is also the government's duty to ensure that management and administration within the civil service will be transparent and trustworthy. Simply reducing the pensions of civil servants (or keeping accumulating arrears), to abate any emerging fiscal crisis may demoralize workers and lead to adverse behavior, such as lack of accountability, deterioration in productivity and a passive attitude to responsibilities. 


\section{APPENDIX C IMPLICIT PENSION DEBT: CROSS COUNTRY COMPARISON $^{37}$}

The IPD represents a fiscal burden that cannot be ignored in low- and middle-income countries. Indeed, it is important to take into account unfunded public pension liabilities as part of an assessment of the overall fiscal situation, including the fiscal positions of pension schemes pre and post reforms.

However, it is important to highlight that this indicator has different methodologies and assumptions and there is no standard way of calculation, hence careful consideration should be given to cross-country comparisons. The estimates are quite sensitive to methodology and definitions.

The definition of the IPD used in this paper represents the present value of pensions to be paid in the future on the basis of accrued rights by the year for which IPD is calculated; neither future contributions, nor the accrual of new rights on the basis of these contributions are considered (the value is assumed under the assumption that the systems closes today ).

Table below presents the IPD estimates for 35 low and middle income countries under alternative discount rate assumptions and compares them with official public debt, expenditure levels, and existing financial reserves (all in percent of GDP). Several results stand out.

First, the estimated IPD is large relative to national incomes in our sample of countries but there is a huge range. Using the two percent discount rate, Brazil's IPD is 500 percent of GDP, ten times more than Morocco. Even using the higher, five percent discount rate, 18 out of 35 countries had IPDs greater than national income.

Not surprisingly, the former socialist countries and especially Central Europe, have the highest IPD burdens measured this way. Of the 19 countries with IDPs of at least 200 percent of GDP, 12 of them are from this region (using a discount rate of 2 percent). This reflects the high labor force coverage that characterized countries in this region and relatively generous benefit levels, combined with an aging population. Uruguay is another country with a large state apparatus and high social expenditure and has the oldest demographic structure in Latin America. At the other end of the spectrum are younger countries like Senegal, Morocco and Uganda where coverage is much lower than what had been found in pre-transition Central Europe. Nevertheless, the levels of pension debt even in these countries is too significant to ignore.

${ }^{37}$ Source: Holzmann, Palacios, Zviniene, 2004 
Table 20: Public debt, pension spending and implicit pension debt for 35 low and middle income countries for various years during the end-1990s and 2000

\begin{tabular}{|c|c|c|c|c|c|}
\hline \multirow[t]{2}{*}{ Country } & \multirow{2}{*}{$\begin{array}{l}\text { Public debt } \\
1999 / 2000\end{array}$} & \multirow{2}{*}{$\begin{array}{l}\text { Pension } \\
\text { Spending }\end{array}$} & \multicolumn{3}{|c|}{ IPD by discount rate } \\
\hline & & & $2 \%$ & $4 \%$ & $5 \%$ \\
\hline & \multicolumn{5}{|c|}{ as share of GDP } \\
\hline Brazil & 33 & 9 & 500 & 330 & 275 \\
\hline Macedonia & 41 & 9 & 441 & 291 & 244 \\
\hline Slovenia & 25 & 11 & 429 & 298 & 255 \\
\hline Romania & 18 & 6 & 386 & 256 & 214 \\
\hline Poland & 43 & 12 & 379 & 261 & 220 \\
\hline Ukraine & 59 & 9 & 365 & 257 & 220 \\
\hline Portugal & 55 & 5 & 358 & 233 & 193 \\
\hline Malta & 56 & 5 & 356 & 234 & 194 \\
\hline Slovakia & 31 & 8 & 304 & 210 & 179 \\
\hline Hungary & 59 & 9 & 300 & 203 & 171 \\
\hline Uruguay & 45 & 14 & 295 & 214 & 187 \\
\hline Kyrgyz Rep. & 135 & 7 & 282 & 185 & 154 \\
\hline Croatia & 33 & 11 & 274 & 201 & 175 \\
\hline Estonia & 7 & 9 & 268 & 189 & 163 \\
\hline Moldova & 78 & 8 & 229 & 159 & 136 \\
\hline Lithuania & 28 & 7 & 221 & 155 & 134 \\
\hline Nicaragua & 109 & 2 & 220 & 131 & 104 \\
\hline Turkey & 65 & 5 & 217 & 146 & 123 \\
\hline Costa Rica & 34 & 2 & 203 & 121 & 97 \\
\hline Philippines & 71 & 1 & 185 & 107 & 81 \\
\hline Iran & 10 & 2 & 146 & 89 & 72 \\
\hline Bolivia & 56 & 4 & 111 & 73 & 62 \\
\hline Argentina & 53 & 5 & 106 & 85 & 78 \\
\hline Ecuador & 209 & 1 & 103 & 63 & 51 \\
\hline Mexico & 19 & 1 & 101 & 65 & 54 \\
\hline Colombia & 24 & 2 & 88 & 56 & 46 \\
\hline Dominican Rep. & 23 & 1 & 80 & 49 & 40 \\
\hline Cape Verde & 52 & 1 & 78 & 47 & 38 \\
\hline Chile & 9 & 7 & 77 & 60 & 53 \\
\hline Senegal & 78 & 2 & 73 & 51 & 44 \\
\hline Mauritius & 35 & 3 & 63 & 47 & 42 \\
\hline El Salvador & 22 & 2 & 60 & 43 & 37 \\
\hline Peru & 43 & 2 & 57 & 40 & 34 \\
\hline Korea & 33 & 1 & 57 & 33 & 26 \\
\hline Morocco & 79 & 1 & 50 & 32 & 26 \\
\hline
\end{tabular}

Sources: Own calculations and public debt data based on SAVEM tables (World Bank), At-a-glance tables prepared for the Annual Meetings (World Bank), and various IMF statistics on Article IV consultations.

IPDs are high relative to conventionally defined public debt for most countries. Only a few countries (Cape Verde, Ecuador, Korea, Morocco, Nicaragua, Peru and Senegal) have higher explicit public debt than IPD even when using the 5 percent discount rate case. This result highlights the importance of this indicator for a proper assessment of long-term fiscal sustainability. It is also a measure of just how difficult a rapid shift from an unfunded system to a funded pension scheme would be in some countries. Last but not least, these figures suggest that pension debt or wealth could be a significant factor in determining savings behavior in many developing countries. 
Beside maturity, differences in these ratios are also due to demographic aging patterns. A higher old-age dependency ratio increases, other things equal, both the IPD and expenditure shares, but differences in future dependency ratios first impact IPD before also translating into higher pension expenditure shares.

It is also important to note that alternative indexation of wage records and benefits changes the estimated IPDs but not dramatically in most countries. Moving from wage to price indexation of benefits reduces IPD, on average, by some 15 to 20 percent, with a lower reduction the higher the discount rate.

Current pension spending levels will fail to reflect reforms that are being gradually phased in or changes to indexation which have large compounded impacts. The IPD numbers capture this, therefore providing a more accurate assessment of the long term burden compared across countries. ${ }^{38}$

${ }^{38}$ Another relevant measure for the purposes of assessing sustainability is the ratio of IPD to the wage bill subject to contributions. Using this measure highlights the problems of poor countries such as Senegal in servicing its IPD despite having a relatively low IPD/GDP ratio. 
Table 21: Estimated IPD for 35 Low and Middle Income Countries - detailed results

\begin{tabular}{|c|c|c|c|c|c|c|c|c|c|}
\hline Country & $\begin{array}{l}\text { Coverage in } \\
\text { population aged } 20+\end{array}$ & $\begin{array}{l}\text { Dependency ratio } \\
\text { in base year (a) }\end{array}$ & $\begin{array}{l}\text { Dependency ratio } \\
\text { in year } 2050 \text { (a) }\end{array}$ & $\begin{array}{c}\text { IPD } \\
\text { wage } / 2 \%\end{array}$ & $\begin{array}{c}\text { IPD } \\
\text { price/2\% }\end{array}$ & $\begin{array}{c}\text { IPD } \\
\text { wage } / 4 \%\end{array}$ & $\begin{array}{c}\text { IPD } \\
\text { price } / 4 \%\end{array}$ & $\begin{array}{c}\text { IPD } \\
\text { wage } / 5 \%\end{array}$ & $\begin{array}{c}\text { IPD } \\
\text { price/5\% }\end{array}$ \\
\hline Argentina & 28 & 47 & 41 & 106 & 91 & 85 & 75 & 78 & 70 \\
\hline Bolivia & 18 & 16 & 24 & 111 & 92 & 73 & 65 & 62 & 55 \\
\hline Brazil & 34 & 28 & 62 & 500 & 362 & 330 & 248 & 275 & 211 \\
\hline Cape Verde & 17 & 5 & 26 & 78 & 64 & 47 & 39 & 38 & 32 \\
\hline Chile & 35 & 13 & 42 & 77 & 64 & 60 & 50 & 53 & 45 \\
\hline Colombia & 22 & 5 & 56 & 88 & 73 & 56 & 48 & 46 & 39 \\
\hline Costa Rica & 33 & 4 & 52 & 203 & 163 & 121 & 100 & 97 & 80 \\
\hline Croatia & 59 & 35 & 72 & 274 & 205 & 201 & 156 & 175 & 139 \\
\hline Dominican Rep. & 20 & 7 & 44 & 80 & 64 & 49 & 40 & 40 & 32 \\
\hline Ecuador & 17 & 9 & 39 & 103 & 78 & 63 & 49 & 51 & 40 \\
\hline El Salvador & 17 & 10 & 47 & 60 & 46 & 43 & 34 & 37 & 29 \\
\hline Estonia & 89 & 44 & 81 & 268 & 213 & 189 & 155 & 163 & 135 \\
\hline Hungary & 78 & 43 & 70 & 300 & 212 & 203 & 150 & 171 & 128 \\
\hline Iran & 26 & 11 & 56 & 146 & 110 & 89 & 70 & 72 & 57 \\
\hline Korea & 22 & $\begin{array}{c}11 \\
1\end{array}$ & 54 & $\begin{array}{c}140 \\
57\end{array}$ & 35 & 33 & 21 & 26 & 17 \\
\hline Kyrgyz Rep. & 70 & 30 & 60 & 282 & 230 & 185 & 154 & 154 & 129 \\
\hline Lithuania & 78 & 50 & 84 & 221 & 164 & 155 & 120 & 134 & 104 \\
\hline Macedonia & 49 & 23 & 77 & 441 & 356 & 291 & 241 & 244 & 204 \\
\hline Malta & 57 & 18 & 58 & 356 & 284 & 234 & $\begin{array}{l}241 \\
190\end{array}$ & 194 & $\begin{array}{l}204 \\
159\end{array}$ \\
\hline Mauritius & 100 & 11 & 60 & 63 & 46 & 47 & 37 & 42 & 33 \\
\hline México & 25 & 7 & 40 & 101 & 84 & 65 & 54 & 54 & 45 \\
\hline Moldova & 73 & 63 & 68 & 229 & 178 & 159 & 127 & 136 & 111 \\
\hline Morocco & 6 & 10 & 53 & 50 & 40 & 32 & 26 & 26 & 22 \\
\hline Nicaragua & 21 & 6 & 33 & 220 & 173 & 131 & 105 & 104 & 84 \\
\hline Peru & 51 & 6 & 26 & 57 & 51 & 40 & 35 & 34 & 30 \\
\hline Philippines & 41 & 2 & 41 & 185 & 146 & 107 & 85 & 81 & 66 \\
\hline Poland & 95 & 24 & 47 & 379 & 304 & 261 & 212 & 220 & 181 \\
\hline Portugal & 78 & 36 & 72 & 358 & 271 & 233 & 181 & 193 & 151 \\
\hline Romania & 53 & 45 & 121 & 386 & 292 & 256 & 199 & 214 & 169 \\
\hline Senegal & 6 & 39 & 78 & 73 & 51 & 51 & 37 & 44 & 32 \\
\hline Slovakia & 81 & 37 & 91 & 304 & 241 & 210 & 171 & 179 & 148 \\
\hline Slovenia & 76 & 33 & 96 & 429 & 314 & 298 & 226 & 255 & 197 \\
\hline Turkey & 35 & 28 & 50 & 217 & 154 & 146 & 109 & 123 & 93 \\
\hline Ukraine & 91 & 42 & 82 & 365 & 292 & 257 & 211 & 220 & 183 \\
\hline Uruguay & 52 & 40 & 61 & 295 & 246 & 214 & 182 & 187 & 160 \\
\hline
\end{tabular}

Notes: (a) Ratio of old age pensioners to contributors; (b) Indexation method applies both to the wage record valorization and to the indexation of pension benefit Source: World Bank Pension Database, and own calculations with PROST Model. 


\section{APPENDIX D OVERVIEW OF PROST 12}

The model consists of an input workbook and five output modules. On the input side, the user provides country specific data on demographic, economic and pension system related parameters and assumptions about their behavior in the future. This information is entered in the input file with six embedded worksheets:

General Economic variables (GDP and wage growth, inflation, interest rate), non age-specific pension system parameters (pension fund balance and benefit expenditure in the base year, retirement age, contribution rate, pension indexation rules, etc.) and some demographic variables;

Population Base year population by age and gender along with age-specific fertility and mortality rates and immigration information.

Labor Age and gender specific labor force participation and unemployment rates as well as distribution of wages and old age pensions across age and gender cohorts.

Pension Age and gender specific information about pension system contributors, beneficiaries, coverage and retirement rates, average years of service at retirement and replacement rates for new beneficiaries.

Profiles Information on representative individuals, such as gender, career path, individual wages, life expectancy, etc.

Reform Parameters relevant to systemic reforms to be simulated (any combination of conventional PAYG, fully funded DC and notional DC pillars), including switching pattern, how the acquired rights will be paid, contribution rates, rules for annuitization and pension payout under DC schemes and replacement rates/benefit formula in a PAYG pillar, indexation, etc.

In the most simplified way the general calculation scheme can be summarized as follows: 


\section{General Calculation Scheme}

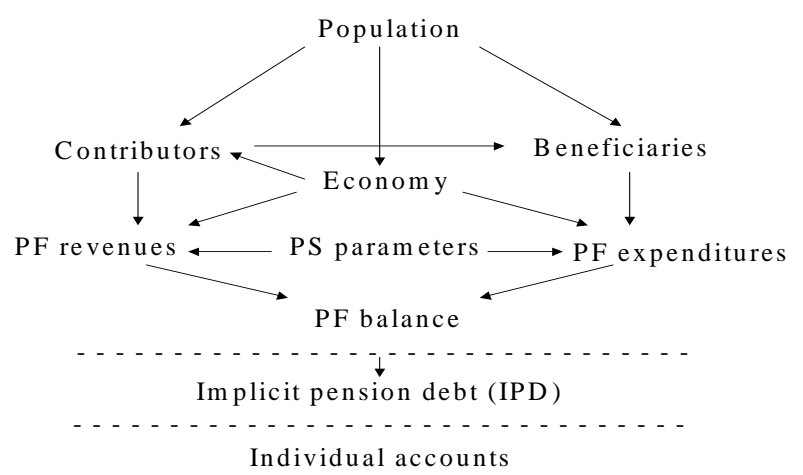

PROST follows single age/gender cohorts over time and generates population projections, which, combined with labor market assumptions, are used to forecast future numbers of contributors and beneficiaries. These in turn generate flows of revenues and expenditure. The model then projects fiscal balances and calculates the implicit pension debt. The required contribution rates and affordable replacement rates for zero pension fund balance in each year of the simulation period are also calculated. Finally, PROST produces outputs related to individuals - what an individual would contribute to the system and what he/she obtain under PAYG DB and multipillar schemes. This allows both intra- and intergenerational analysis.

Depending on the characteristics of the pension system and data availability, the user can choose the method for calculation of some of the variables. In particular, the number of contributors and beneficiaries can be computed in either "Stock" or "Flow" method. With the "Stock" method, for each year the stocks of contributors/beneficiaries are calculated first and then inflows (new contributors/beneficiaries) are derived as the changes of the stocks:

$$
\operatorname{Inflow}(a, t, g)=\operatorname{stock}(a, t, g)-\operatorname{stock}(a-1, t-1, g)+\operatorname{outflow}(a, t, g)
$$

With the "Flow" method, inflows are calculated first and then stocks are derived as previous year's stocks in each age/gender cohort adjusted for the net inflow (inflowoutflow):

$$
\begin{gathered}
\operatorname{Stock}(a, t, g)=\operatorname{stock}(a-1, t-1, g)-\operatorname{outflow}(a, t, g)+\operatorname{inflow}(a, t, g) \\
\text { where a = age, } \mathrm{t}=\text { year, } \mathrm{g}=\text { gender }
\end{gathered}
$$

As PROST keeps track of contribution years of service accrued by each cohort, the calculated number of new retirees - whatever method is used - is then adjusted so that the total length of service accrued by the cohort is equal to the total length of service 
claimed by the cohort at the time of retirement. After the number of new retirees is adjusted, the stock is recalculated using the "Flow" method.

The user can also choose how the benefit of new beneficiaries is specified - via benefit formula or via age and gender specific replacement rates.

As mentioned above, output produced by PROST is organized in five output modules. Each of the modules contains a number of Excel worksheets and a graphical summary on key output indicators:

Population Projection Population projections and pyramids, life tables, life expectancy changes, population dependency rates, etc.

Demographic Structure

Finances of Monopillar PAYG

Finances of Multipillar System

Individual accounts
Labor force and employment projections, projections of contributors and beneficiaries, demographic structure of the pension system, and system dependency rates.

Macroeconomic trends, wage projections, pension benefit projections for the existing and new pensioners, revenue and expenditure of the pension system, required adjustments to contribution rates and replacement rates for zero current balance, and the implicit pension debt.

Pension benefit projections for new and existing pensioners under each of the three pillars (conventional PAYG, notional PAYG, and funded DC), revenues and expenditure of both PAYG and funded pillars, implicit pension debt of the PAYG system after the reform, and results of the reform (compares benefit projections and financial standing under the monopillar PAYG and multipillar scenarios).

Lifetime contributions and benefits and individual related summary statistics for up to six different individuals specified in the "Profiles" input sheet under PAYG system (statutory, with adjusted contribution rates and with adjusted benefits) and multipillar system (for those who switched to the multipillar system and those who remained in the PAYG system). 


\section{APPENDIX E IMPACT OF REFORMS ON INDIVIDUALS}

Considerations on pension benefit adequacy, distributional and equity issues are as important in the assessment of pension reform options as considerations on financial sustainability, affordability and fiscal impact. Individuals with four different profiles representing the four different groups of employees were modeled to compare how they would fare under each of the reform options presented in the paper: (1) a pure DC reform (referred to in the paper as Reform I), and (2) a hybrid reform (referred to as Reform II). Since in funded DC schemes benefits are very sensitive to the interest rate earned on individual accounts, variants with 5\% and 3\% real rate of return on assets were considered for each reform option.

The study targeted individuals of different gender and - within each gender group with different job entry ages, income level, earning profile, and mortality rates. The specific individual profiles were selected in consultations with and based on the data provided by our Ugandan counterparts from the MPS. Four types of individuals specified by entry age, income level, and life expectancy were considered for each gender.

1) Lifetime low income worker (approximating the average career of a Teacher or Policeman):

a) Starts working at age 18 and retires at 60;

b) Wage starts at about $50 \%$ of the age/gender cohort average and sustains that ratio throughout the person's career;

c) Individual's life expectancy is assumed to be lower than for the respective age and gender group of the general population by applying $110 \%$ adjustment coefficient to mortality rates.

2) Lifetime average income worker (approximating the average career of a Head Teacher):

a) Starts working at age 20 and retires at 60;

b) Earns age/gender cohort average wage throughout his/her career;

c) Individual life expectancy is assumed to be equal to the respective age and gender group’s average.

3) Lifetime high income worker (approximating the average career of a Commissioner):

a) Starts working at age 25 (after getting higher education) and retires at 60;

b) Wage starts at about $150 \%$ and increases to about $250 \%$ of the age/gender cohort average by the end of the person's career;

c) Individual life expectancy is assumed to be higher than for the respective age and gender group of the general population by applying $90 \%$ adjustment coefficient to mortality rates.

4) High income worker with a steep earning profile (approximating the average career of a Permanent Secretary):

a) Starts working at age 20 and retires at 60; 
An Assessment Of Reform Options For The Public Service Pension Fund In Uganda

b) Wage starts at $100 \%$ and increases to about $300 \%$ of the gender/cohort average by the end of the person's career;

c) Individual life expectancy is assumed to be higher than for the respective age and gender group of the general population by applying $90 \%$ adjustment coefficient to mortality rates.

These four representative individuals are assumed to retire at the statutory retirement age of 60. This is motivated by the fact that in all reform scenarios participants are discouraged from early retirement by the close link generated between benefits and contributions. Life expectancy is modeled to be correlated to income level, in accordance with the observed tendencies around the world. Since currently the Government is only considering pension reform options affecting only new entrants in the labor force, the four representative individuals described above are assumed to join the system in the year 2007 - the reform year. The real discount rate used in all present value calculations is $5 \%$.

We initially assess the impact of the reforms in terms of relative pension levels and pension wealth in relation to the status quo: the no-reform or baseline scenario. Subsequently we compare the results of the two reform option: the pure DC and the hybrid reforms.

Relative pension levels are reported below in Figure 45 and Figure 46. Relative pension level is defined as the individual pension at retirement divided by the economy-wide average wage. Figure 45 reports the relative pension levels projected for our four different types under the no-reform - baseline - scenario modeled in the main body of this paper. Figure 46 reports relative pension levels projected for our four different types under the reform scenarios modeled in the main body of this paper. 
Figure 45: Projected Pension Entitlements as a Proportion of the Average Wage $^{39}$ under No-Reform Scenario

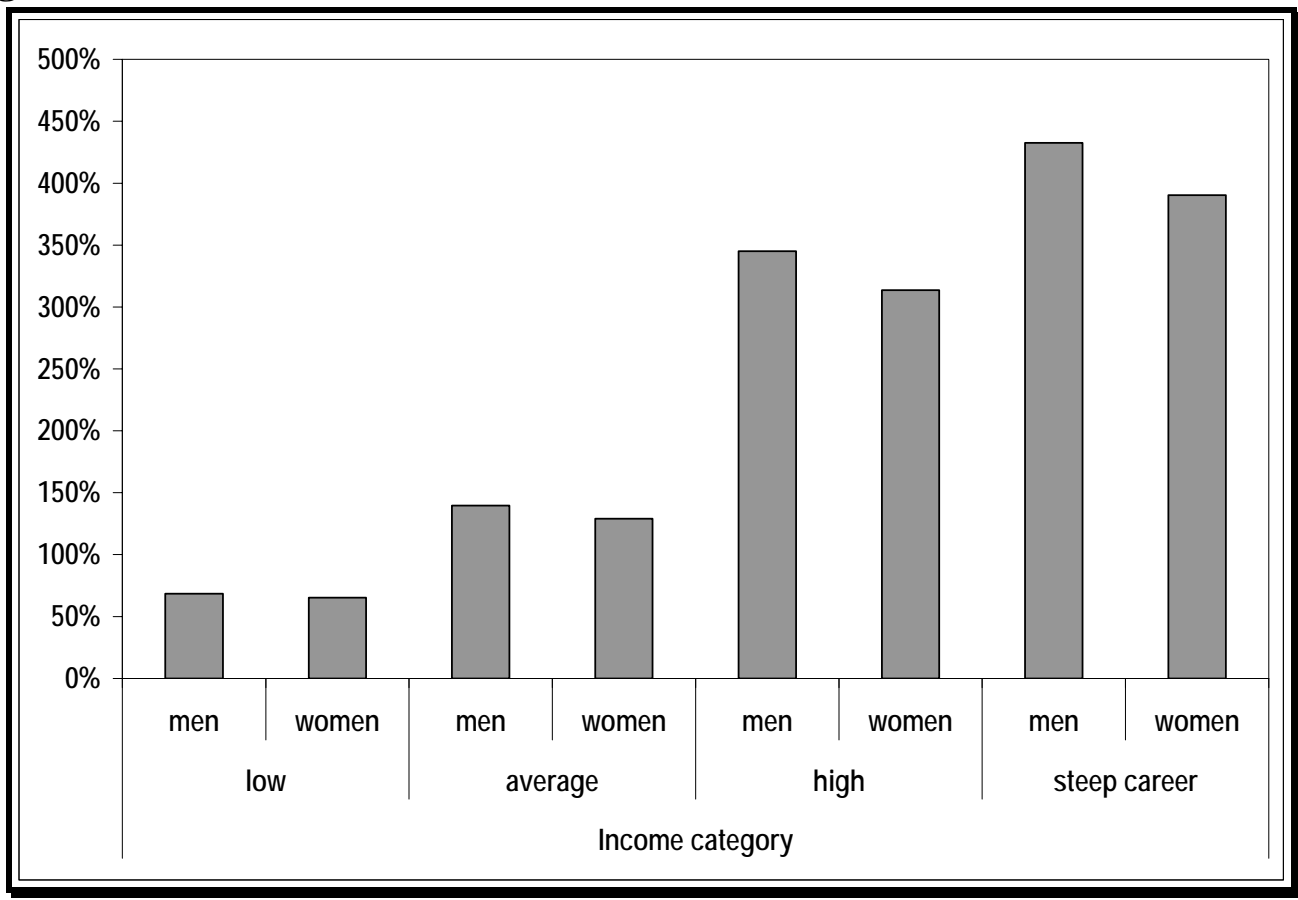

Source: WB calculations

Figure 46: Projected Pension Entitlements as a Proportion of the Average Wage $^{40}$ under the Reform Scenarios

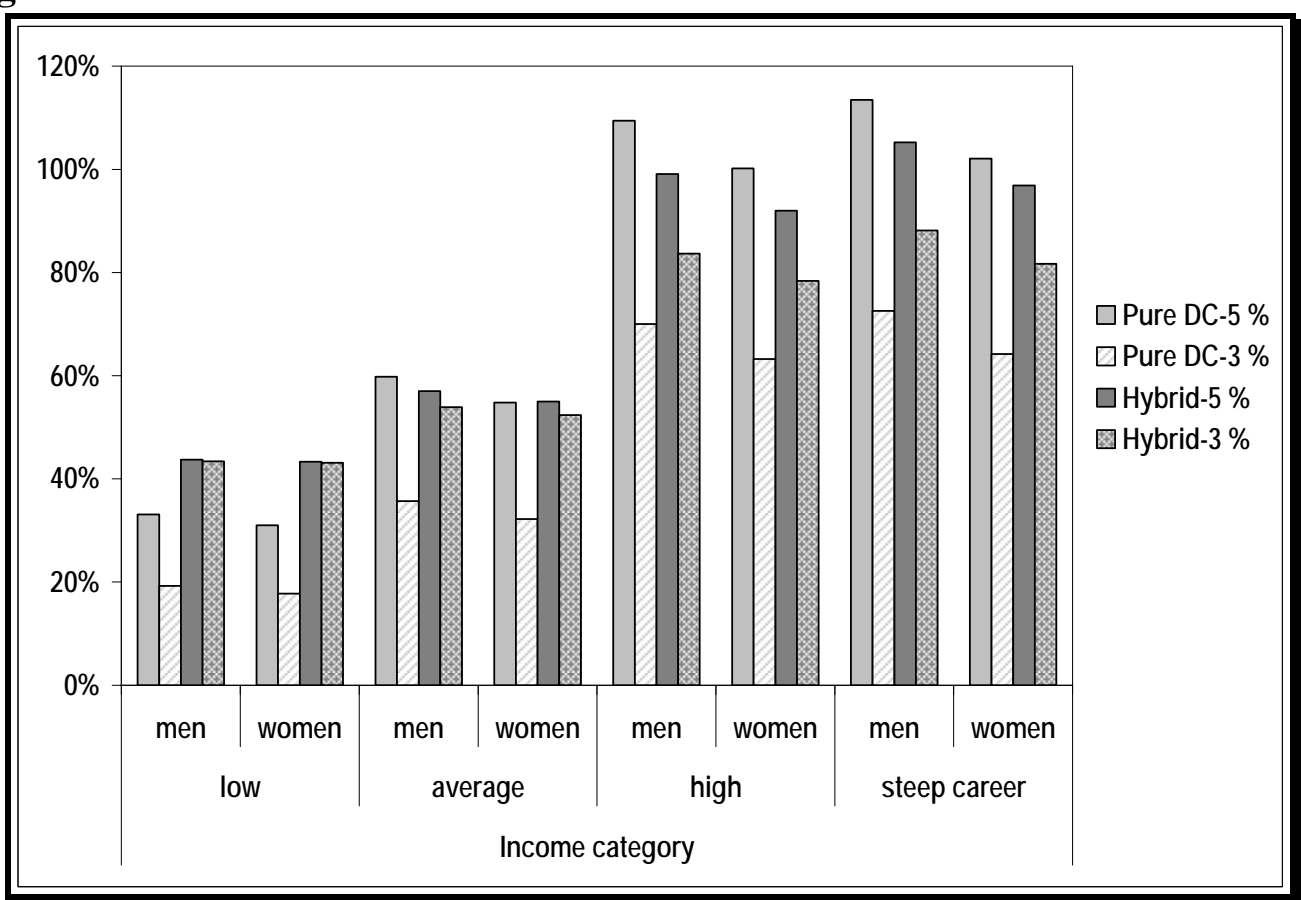

Source: WB calculations

${ }^{39}$ The average wage for civil servants in the year of individual's retirement

40 The average wage for civil servants in the year of individual's retirement 
All income and gender groups would receive significantly higher benefits under the current generous system if no reform is introduced. With no minimum pension, no ceilings on pensionable wages and with individual's last wage used as the wage base in pension calculations, relative pension levels linearly increase with individual preretirement wage in the no-reform scenario - the current situation. This type of a system favors higher income workers, especially those with steeper individual earning profile.

The introduction of any of the two reform options results in a considerable reduction of expected benefits across all income groups and for both genders compared to the noreform option. At the same time, the extent to which individuals are affected by reforms varies substantially depending on individual's pre-retirement income level. In addition, since both the pure DC and the hybrid system reform options establish a close link between individual's benefit and lifetime earnings, the reduction in expected benefits is stronger for individuals with higher pre-retirement income. ${ }^{41}$ This is shown in Figure 47 where in both reform options, the higher the individual's last wage, the higher the difference in relative pension levels relative to the no-reform scenario.

Figure 47: Post reform Relative Pension Levels as a share of No-Reform Relative Pension Levels

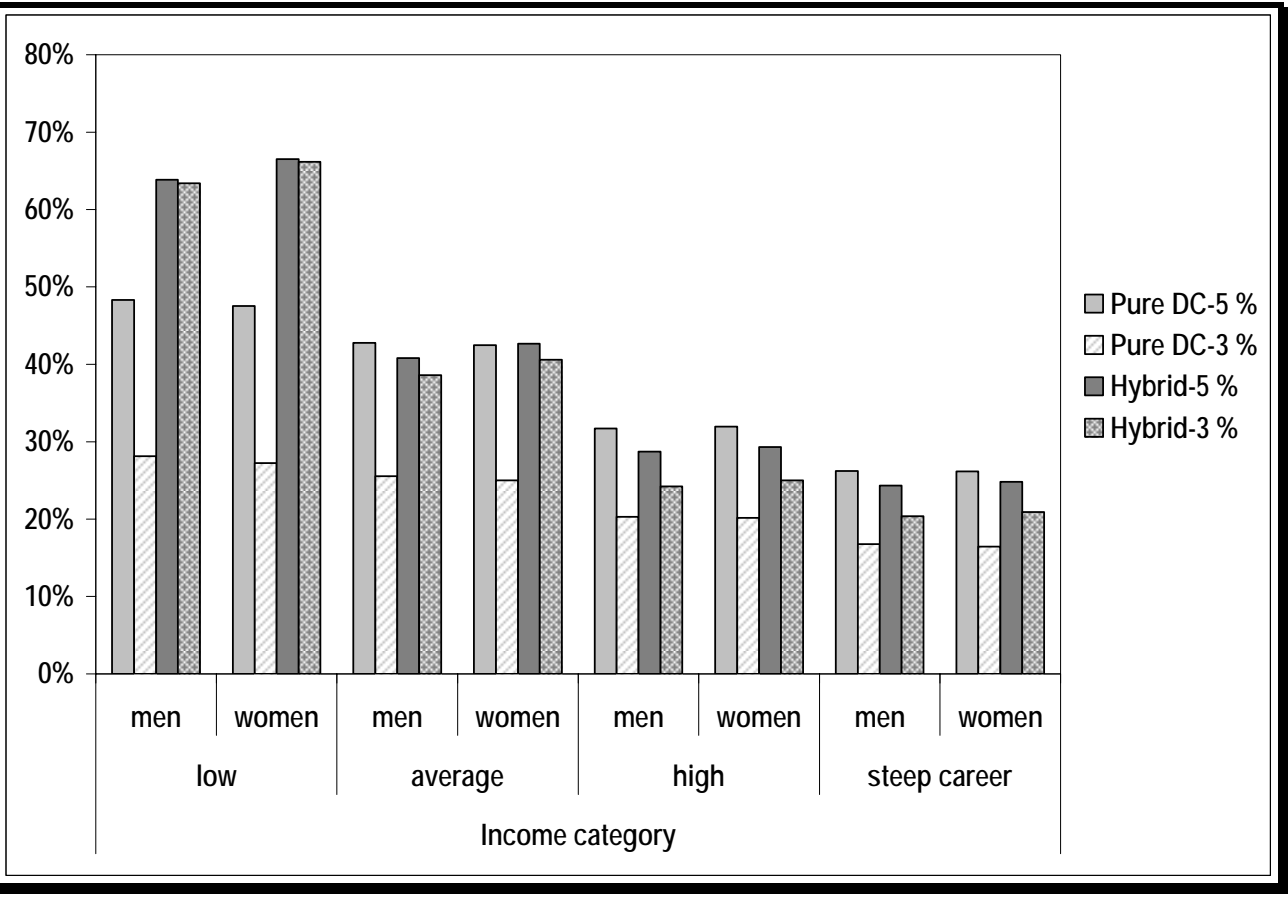

Source: WB calculations

Another useful indicator in the analysis of the impact of reforms on individuals is pension wealth which is calculated as the present value at retirement of future pension benefits. While replacement rates and relative pension levels measure the value of benefits per time unit, pension wealth quantifies what an individual would expect to receive from the pension system over his lifetime at retirement. The usefulness of pension wealth is

\footnotetext{
${ }^{41}$ Higher pre-retirement income is determined by longer working life, higher wage levels, higher wage growth or any combination of these factors.
} 
related to the fact that, contrary to the relative pension level, it captures the effect of changes in benefit indexation with the reform.

As done before, pension wealth under the reform scenarios is compared with the noreform pension wealth benchmark in Figure 48. Notice that the pension wealth in the reform scenarios falls in relative terms by more than the relative pension level as with the reform post-retirement pension indexation changes from wage to prices.

Figure 48: Pension Wealth as a Portion of No-reform Pension Wealth

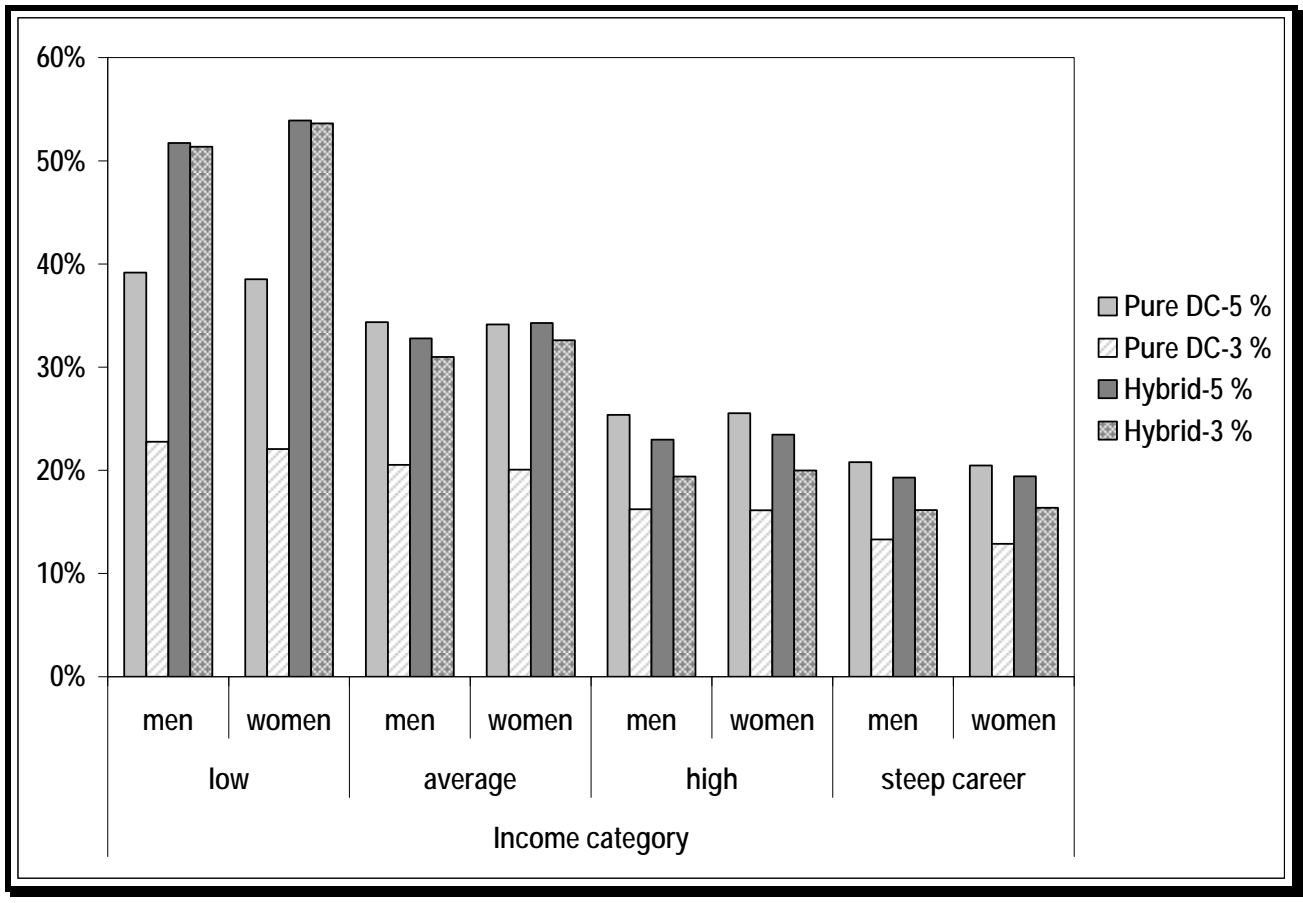

Source: WB calculations

We now compare the results for the two reform options.

When the two reform options are compared, low income workers will be better off under the hybrid scheme than under the pure DC option, regardless of the assumed interest rate earned on individual accounts. With no minimum pension guarantee in the pure DC reform option, the expected benefit for this group may drop below $20 \%$ of the average wage. Even under the optimistic scenario of $5 \%$ real rate of return on investments they can get only about $30 \%$ of the average wage which is lower than what most countries target as the as a minimum pension. On the contrary, the hybrid scheme option may significantly reduce investment risk for low income earners, providing at the same time an acceptable benefit level of $43-44 \%$ of the average wage.

Under the more optimistic scenario (5\% real interest rate), the expected benefits for the average income group in the pure DC system will be very similar to those in the hybrid system: $60 \%$ of the average wage for men and 55\% for women in the pure DC option versus 57\% for men and 55\% for women in the hybrid option. But, in the likely event of lower interest rates (3\% real), this group will do much better under the hybrid scheme $36 \% / 32 \%$ versus 54\%/52\% respectively. Though in the hybrid scheme average wage 
earners remain exposed to investment risk, variations in the interest rate have much less impact on benefits compared to the pure DC option.

For higher income groups, the pure DC system may look more attractive than the hybrid scheme, but only under the optimistic scenario with respect to the interest rate earned on individual accounts. If the real rate of return on assets sustains at $5 \%$ throughout their career, the two top income groups can get from $100 \%$ to $113 \%$ of the average wage, whereas under the hybrid reform option their expected benefits are by 5-10 percentage points lower. On the contrary, under the less optimistic scenario these groups will be better off in the hybrid scheme: 78\%-88\% in the hybrid versus 63\%-73\% in the pure DC scheme.

Another indicator that can be used to compare the pure DC reform option with the hybrid reform option is the Internal Rate of Return (IRR). In a contributory system workers are supposed to pay contributions, in which case their participation in the pension system can be considered as an investment. Hence, the IRR can be used as a comprehensive measure of the level of benefits that an individual would obtain relative to what he/she would pay into the system in the form of contributions. ${ }^{42}$ This indicator takes into account individual's overall wage and contribution history, retirement age and expected number of years in retirement, initial benefit and its post-retirement indexation. Table 22 summarizes projected IRRs by gender and income group.

Table 22: Projected Internal Rates of Return

\begin{tabular}{|l|r|r|r|r|r|r|r|r|}
\hline \multirow{2}{*}{ Reform option } & \multicolumn{9}{|c|}{ Income category } \\
\cline { 2 - 9 } & \multicolumn{2}{|c|}{ low } & \multicolumn{2}{c|}{ average } & \multicolumn{2}{c|}{ high } & \multicolumn{2}{c|}{ steep career } \\
\cline { 2 - 9 } & men & women & men & women & men & women & men & women \\
\hline Pure DC-5 \% & $7.3 \%$ & $7.1 \%$ & $7.5 \%$ & $7.3 \%$ & $7.8 \%$ & $7.6 \%$ & $7.7 \%$ & $7.7 \%$ \\
\hline Pure DC-3 \% & $5.0 \%$ & $4.7 \%$ & $5.3 \%$ & $5.0 \%$ & $5.6 \%$ & $5.4 \%$ & $5.5 \%$ & $5.5 \%$ \\
\hline Hybrid-5 \% & $8.9 \%$ & $8.9 \%$ & $7.8 \%$ & $7.8 \%$ & $7.7 \%$ & $7.6 \%$ & $7.7 \%$ & $7.8 \%$ \\
\hline Hybrid-3 \% & $8.9 \%$ & $8.9 \%$ & $7.5 \%$ & $7.6 \%$ & $6.8 \%$ & $6.8 \%$ & $6.8 \%$ & $6.9 \%$ \\
\hline
\end{tabular}

Source: WB calculations

Under the more optimistic interest rate scenario (5\% real), high income groups may expect about the same rate of return by participating in either of the two schemes. For average wage earners hybrid scheme seems to be slightly more attractive, and for the low income group the IRR in the hybrid scheme exceeds what they may expect from a pure DC scheme by $22-26 \%$. Under the less optimistic interest rate (3\% real), all income groups benefit from participation in the hybrid scheme: the lower the income, the higher the IRR in the hybrid relative to the pure DC scheme.

Overall, the hybrid scheme reduces the investment risk for all contributors: the lower the income, the lower is the investment risk under the two-pillar compared to the pure DC option. Thus, more income security for system participants can be achieved through risk diversification in the hybrid reform option. In addition, it provides higher benefits for the lifetime poor relative to what they may get from the monopillar DC scheme. While in the latter the rate of returns are very similar across all income groups as well as across

\footnotetext{
${ }^{42}$ Obviously, the IRR cannot be calculated for the baseline scenario as under the status quo, the system is non-contributory.
} 
genders, in the former there is some redistribution from higher to lower income groups through it's first pillar. 


\section{APPENDIX F IMPACT OF WAGE INDEXATION}

One possible measure to reduce financial burden without introducing any radical changes to the existing PAYG defined benefit system is switching from wage to price indexation. By changing the rules for recalculation of post-retirement benefits, this measure does not affect pensions of new retirees, but results in lower average pensions for the stock of beneficiaries. Once the impact reaches its full range in about 30 years, the average replacement rates for all existing old age pensioners decrease by about 10-12 percentage points compared to what the retirees may expect from wage indexation (Figure 1). At the same time, even with price indexation, benefits remain at a relatively high level of about $55-60 \%$ of the average wage.

Figure 49: Projected average replacement rates* for the stock of retirees (reduced pension only)
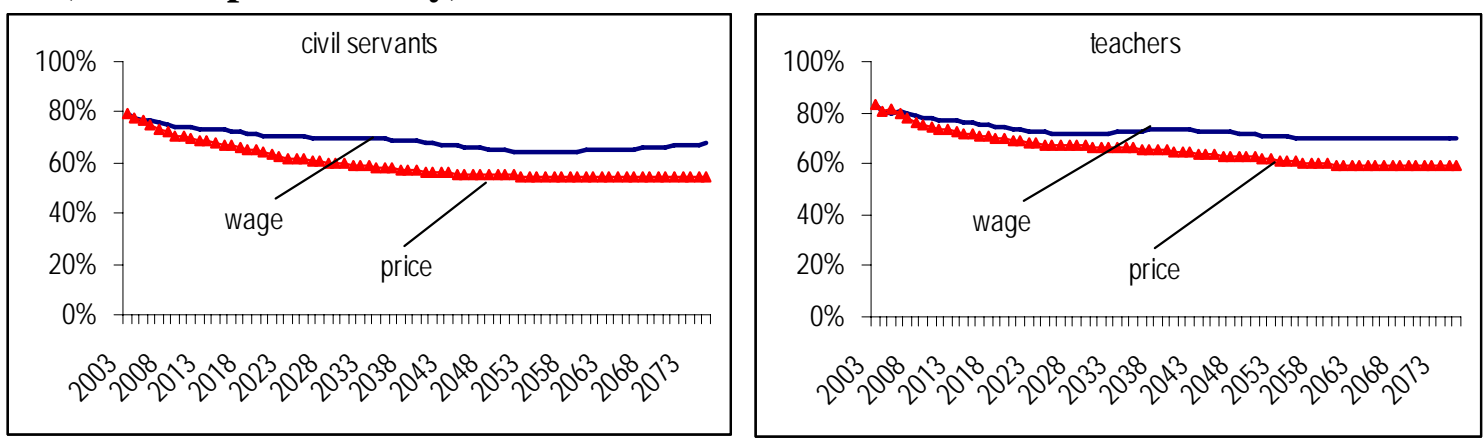

Notes: * Ratio of the total number of beneficiaries in all categories to the total number of active employees.

Source: WB calculations based on PROST

However, price indexation alone can not be sufficient to resolve the key problems with the current scheme. Even though in the long run the total expenditures will decrease by $10 \%-12 \%$, they will continue to grow as a share of GDP - from the current $1 \%$ to about $4 \%$ (two sub-schemes combined). Figure 2 compares projected expenditures with wage and price indexation.

Figure 50: Projected pension expenditure (\% of GDP)

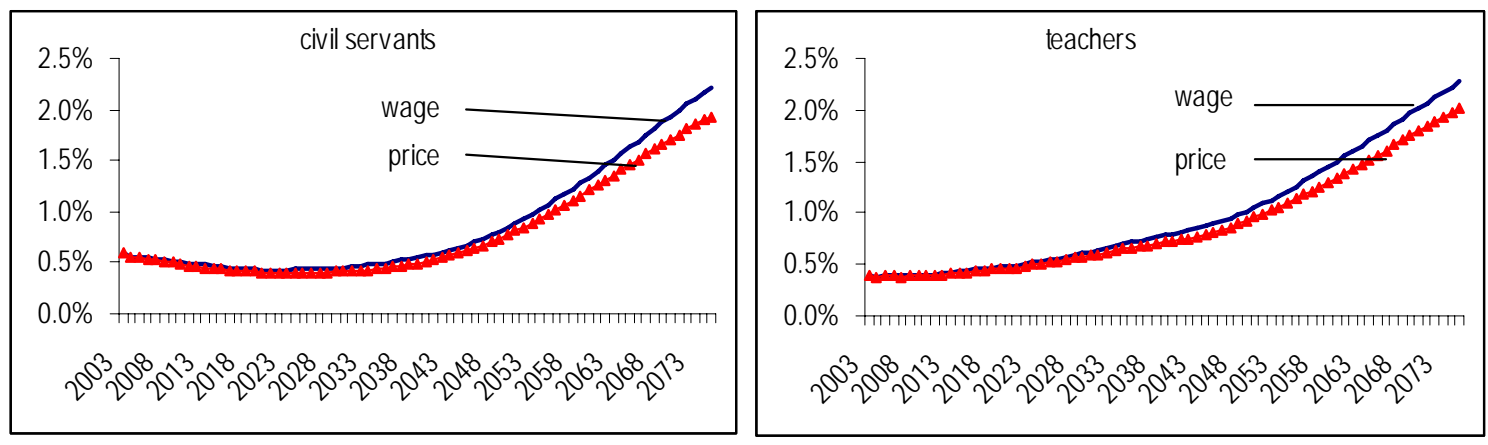

Source: WB calculations based on PROST

With price indexation, the sustainable contribution rates can be reduced only from $33 \%$ to $30 \%$ for civil servants and from $40 \%$ to $36 \%$ for teachers. The financing gap is projected to be lower only by 5 percentage points for each sub-scheme: down to $48 \%$ of the base 
year GDP from 53\% and 55\% from 60\% for civil servants and teachers respectively. The impact of price versus wage indexation on the IPD is compared in Figure 3.

\section{Figure 51: Projected implicit pension debt* (\% of GDP)}

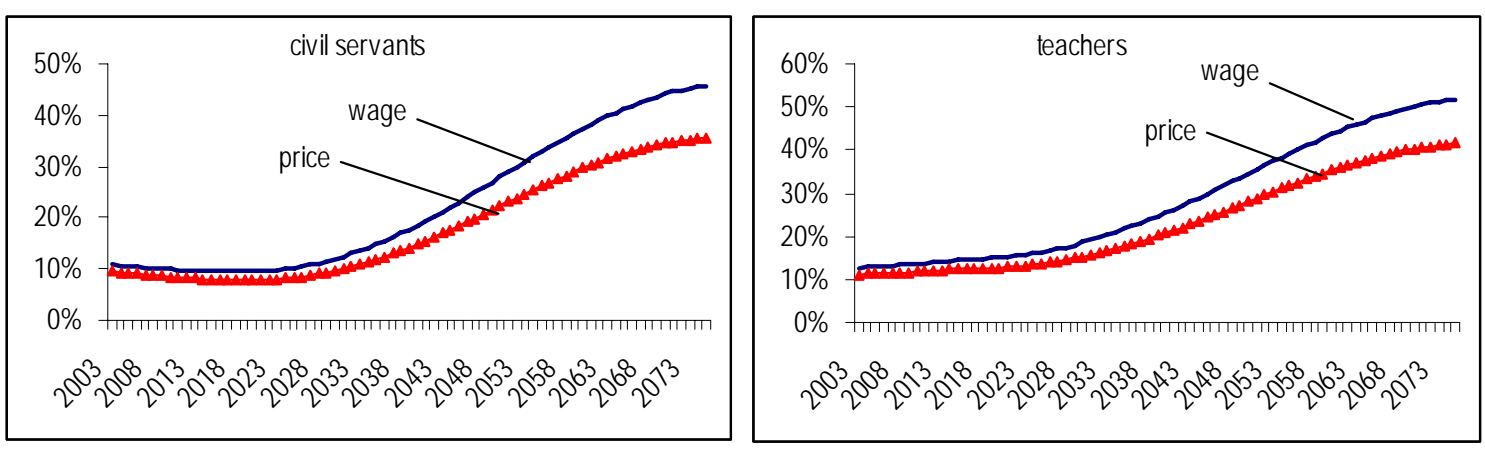

Notes: * liabilities accrued by the system at a given point in time

Source: WB calculations based on PROST 